\title{
Jamshid Khani Mamm- Ka Hamisha ba lagal Khoida daibrd As an example of Magic realistic Novel
}

\author{
Darya Jamal Hawezi ${ }^{1}$
}

Received: March 11, 2016

Reviewed: April 14, 2016

Accepted: May 11, 2016

\begin{abstract}
One of the most well-known theories on which the literary texts are built is realism. Since Society is the main topic of the novel and realism shows the reality of the Society in an artistic way. So Novel was one of the Subjects that realism Paid attention to - From a long time ago Kurds have been Suffered from various hard situations this makes the Kurdish realistic literature to be appeared esp. after Second world war, realism can be noticed in Kurdish Novels at the beginning of appearing Kurdish novel till now. Magic realism is the newest doctrine of realism. This expression has been spread in 0s of past century, It is appeared with appearing American writer's works esp. with receiving Nobel by the Colombian writer Gabriel Garcia Marquis in 1982 when it is noticed by the critics. Magic realism relates to those texts that depend on Legends and national culture and habits. Bakhtyra Ali is a young Novelist that has published (10) novels up to date, and he has published this novel in (2010) the main event of this novel is that poor Jamshid khan will be imprisoned by Ba 'as' regime, due to the punishments that he gets down, because of that in his future life the wind will raise and take him thus they will tie him with a robe so as not to fly with the wind, that cause him to face many hard situations, This and showing other cultural traditions in the society will make us to consider this novel as Magical realism. The reason to choose this topic is the newest genre of realism is the magical realism that is why this research has been conducted, So as to show this new Style of realism in a Kurdish novel. In this research both types of methods have been used in explanatory and descriptive method. In the research we come to some results. The most interesting ones are: Magical Realism has many followers and supporters and that is because its concerns are about groups. This style could develop and speared more among nations' literature. The Kurdish novelist Bakhtyar Ali by following the realism style with a fantastic imagination made a legendary Magical realism in Kurdish literature.
\end{abstract}

Keywords: Novel, Realism, Markiz, Bakhtyar Ali, Kurdish novel

\section{Recommended citation:}

Hawezi, D. J. (2016). Jamshid Khani Mamm- Ka Hamisha ba lagal Khoida daibrd As an example of Magic realistic Novel. International Journal of Kurdish Studies 2 (3), 38 - 57.

1 Lecturer, Department of Kurdish language, Faculty of education, Koya University

Daniel Mitterrand Boulevard, Koya KOY45, Kurdistan Region - F.R. Iraq. email;

Darya.Jamal@koyauniversity.org 
(جهمشيدخان ى مامم ـ كه هلميشه با للهكَّل خوّيدا دهيبرد)

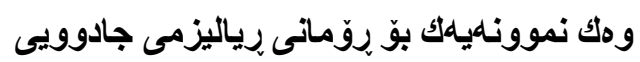

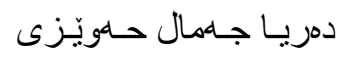

كورته

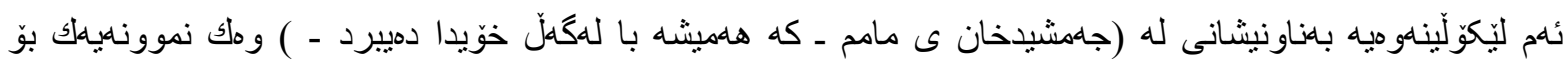

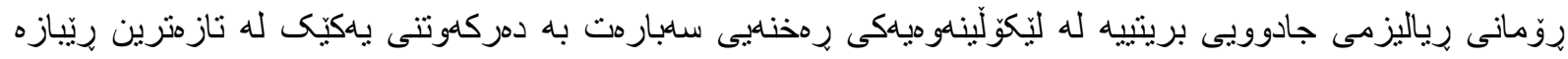

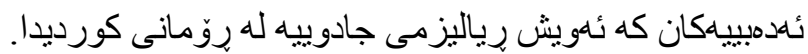

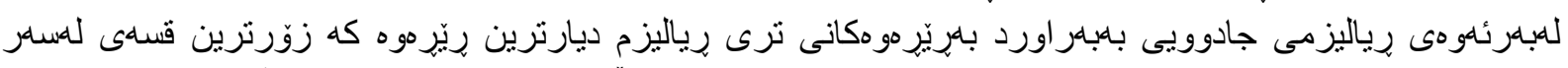

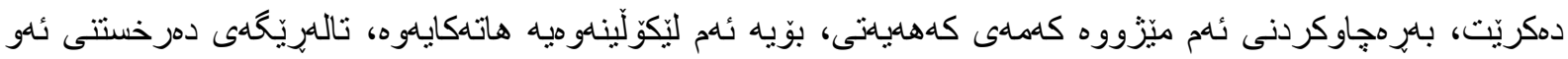

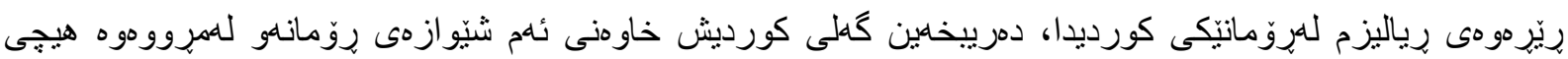

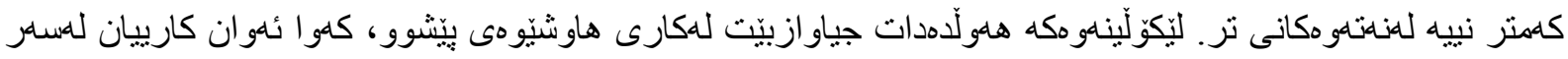

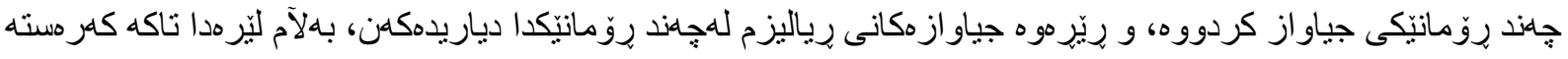

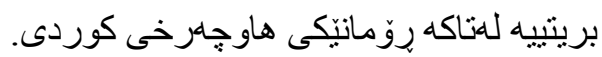

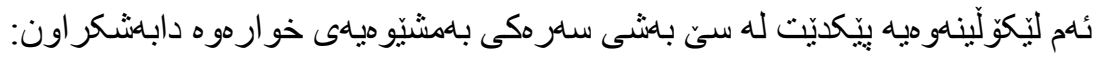

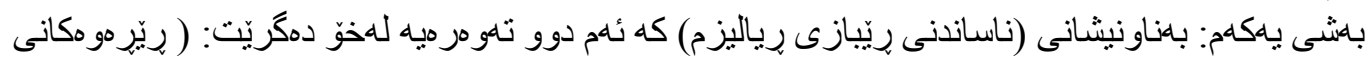

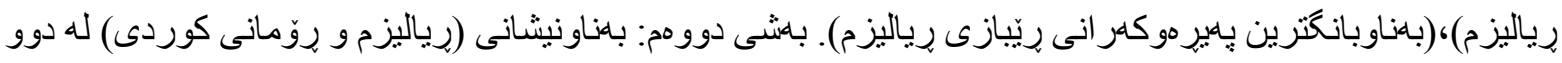

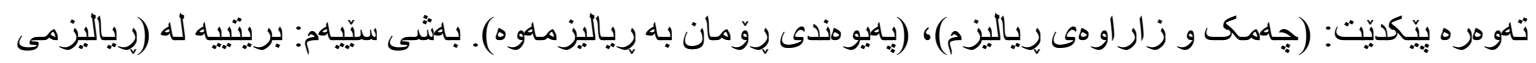

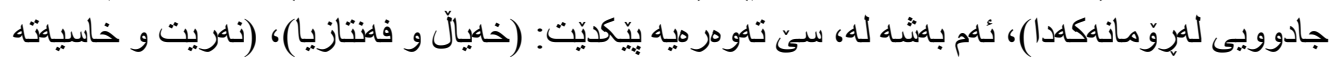

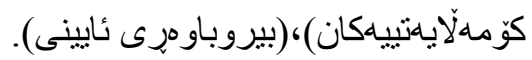

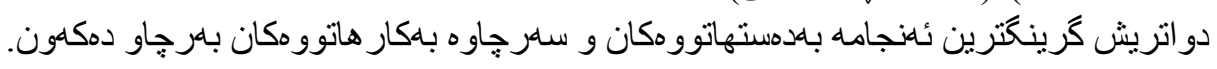
كليله وشهكان: روّمان، رياليزمى جادوويى، ماركيز، روّمانى كوردى، بهختيار عهلى. 


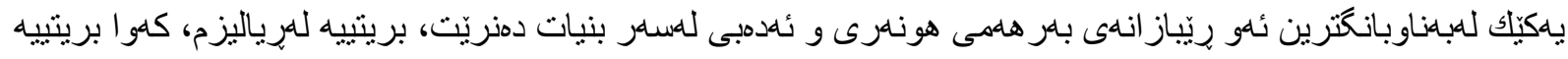

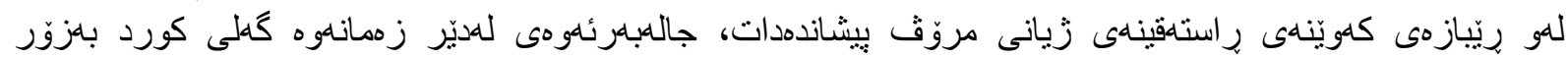

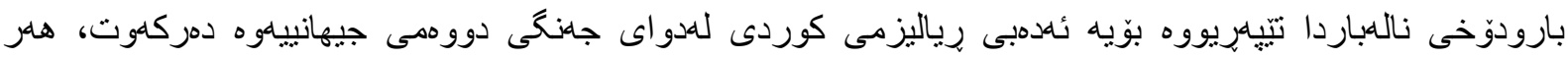

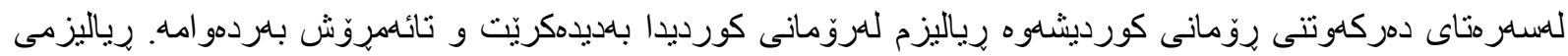

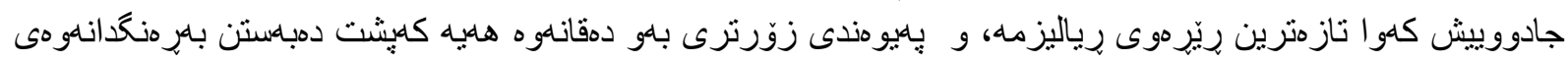

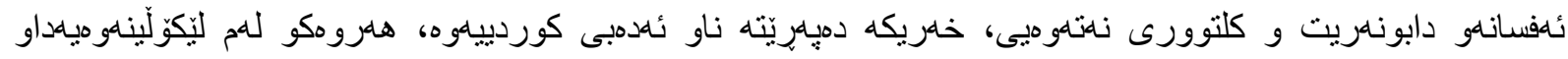

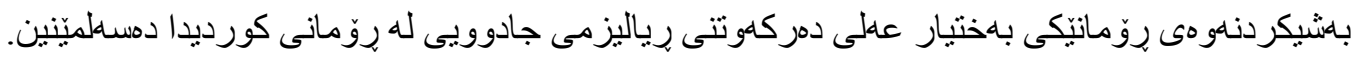

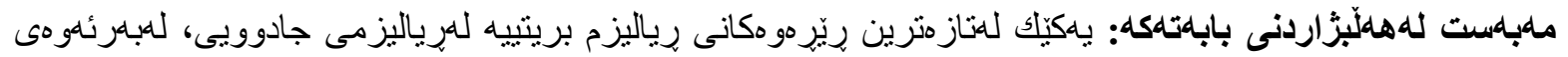

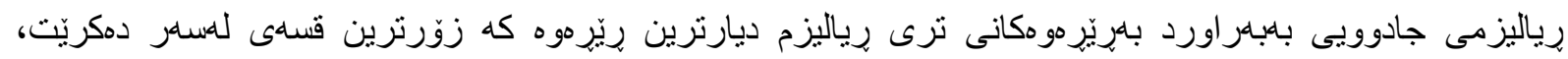

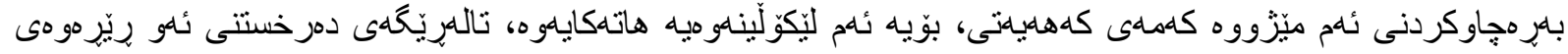

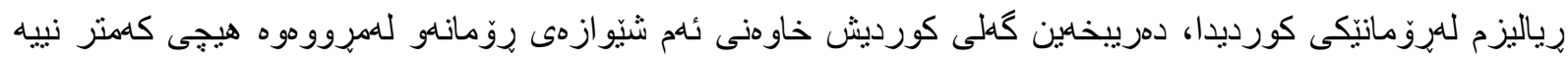

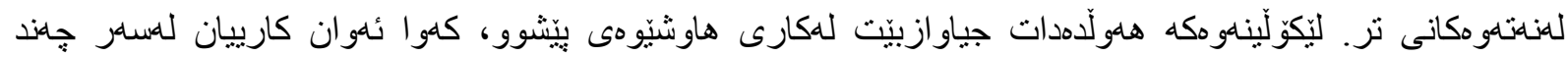

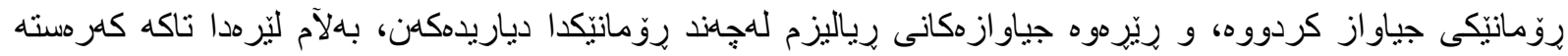

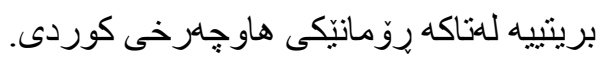

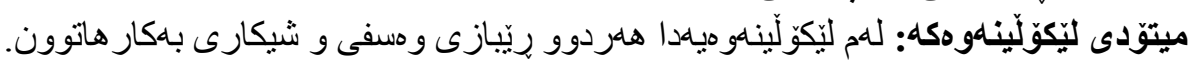

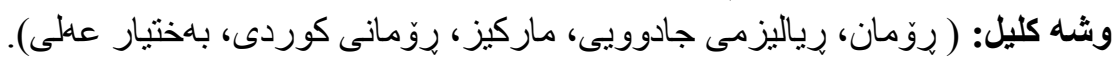

\section{بالشى ياككةم

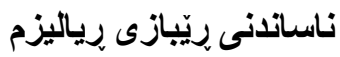

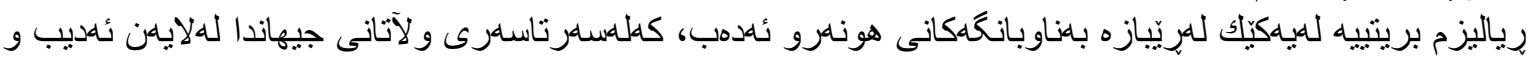

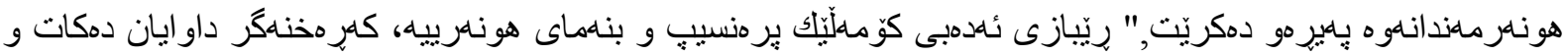

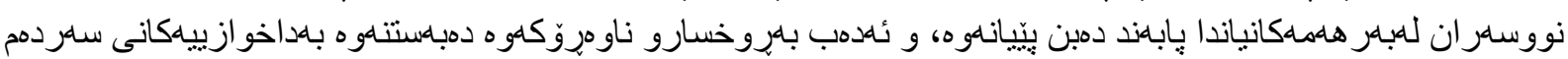

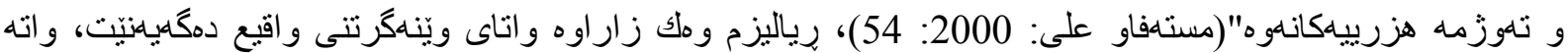

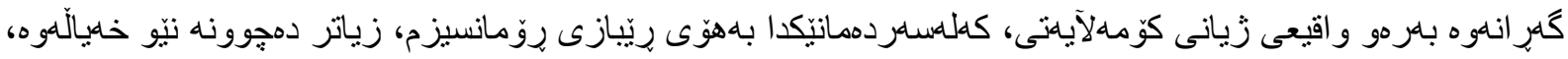

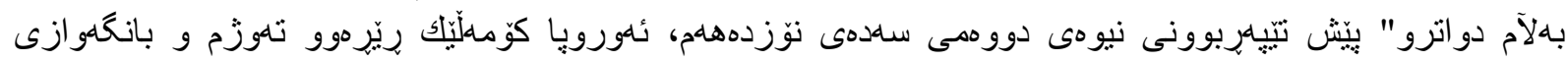

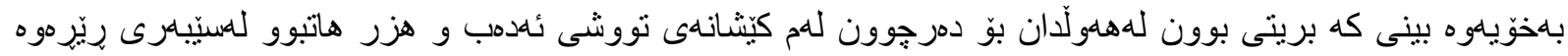

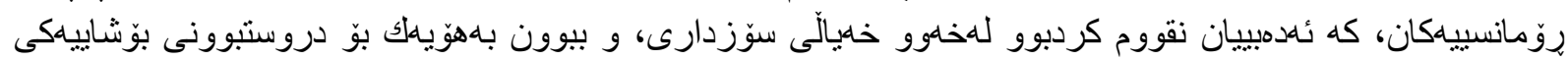

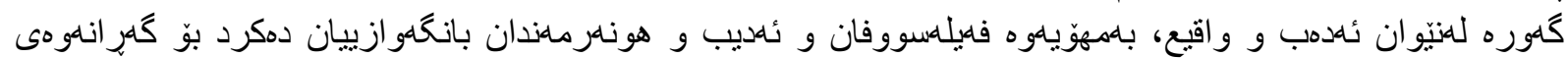

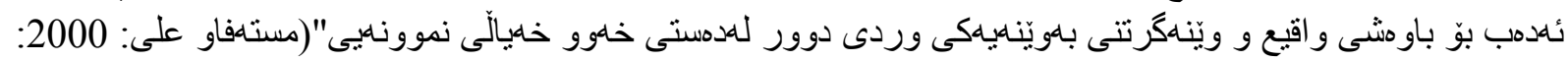

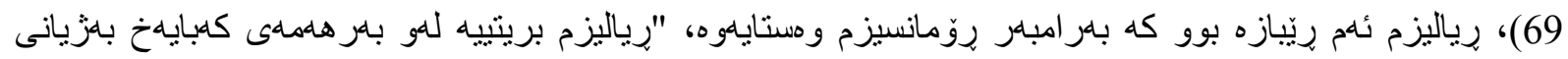

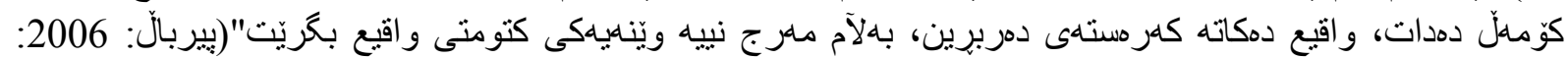

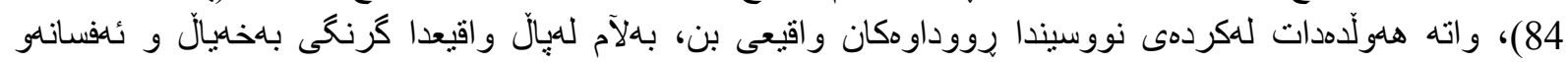

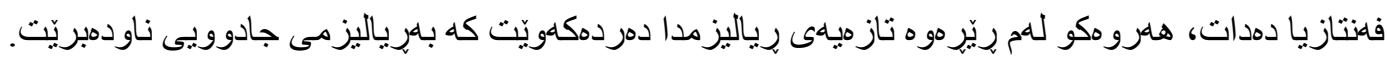

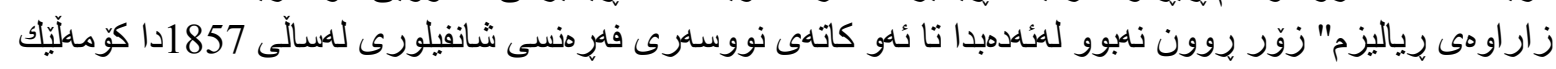

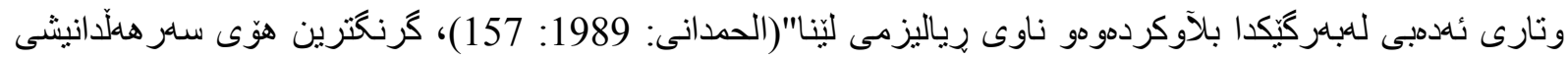

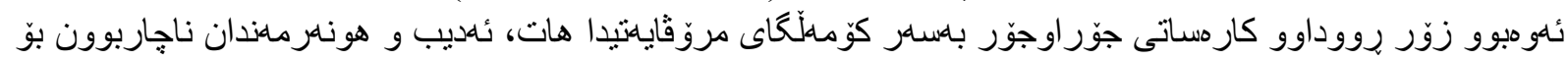

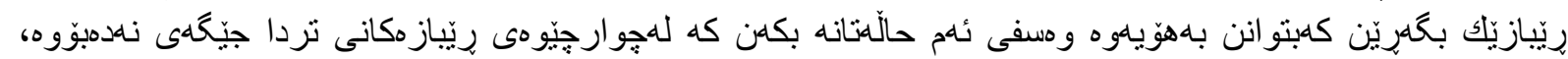

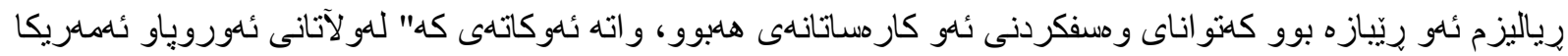

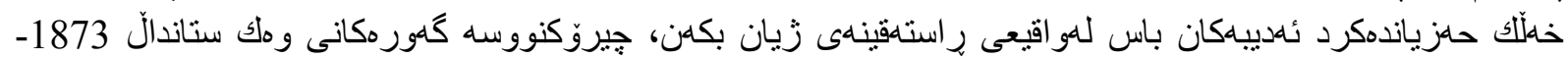

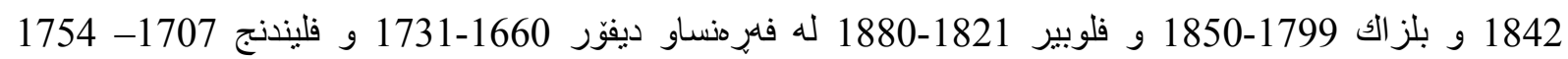

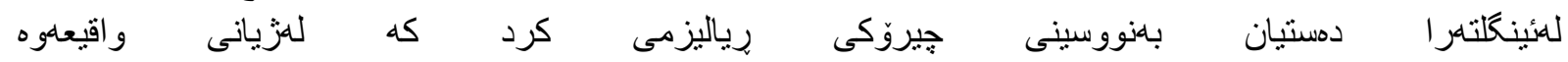




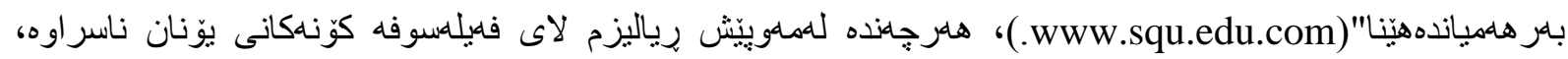

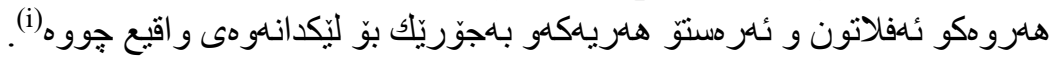

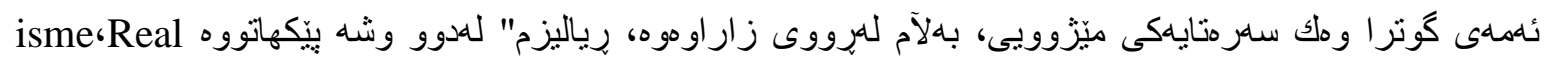

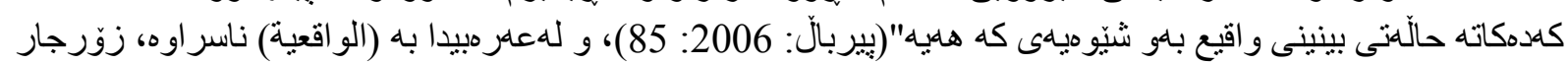

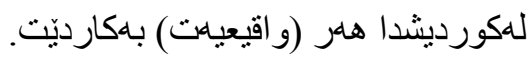

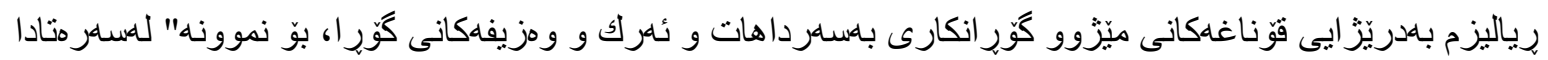

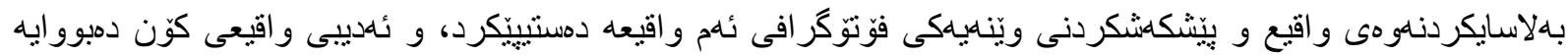

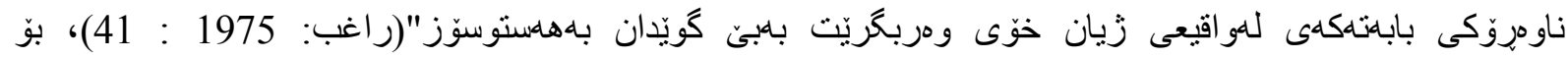

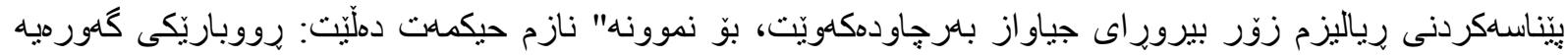

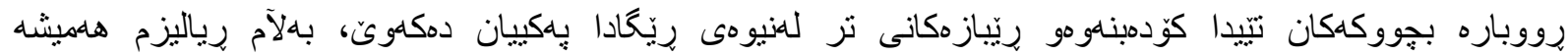

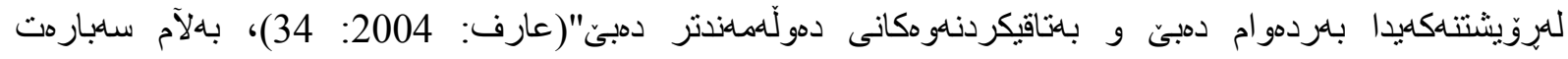

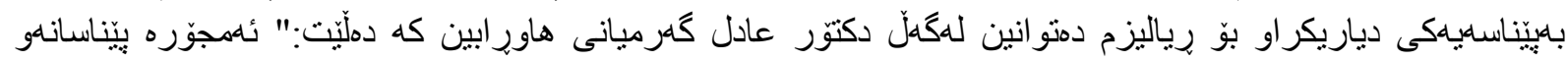

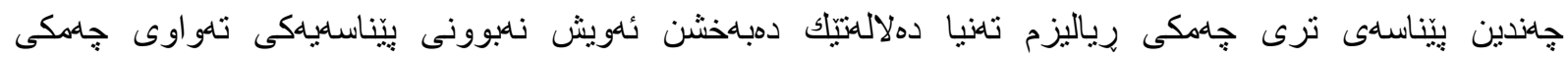

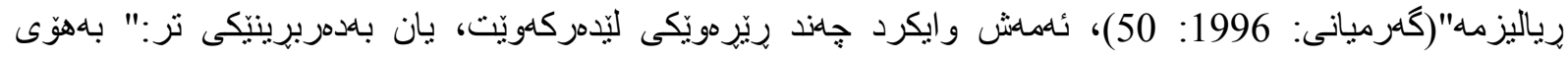

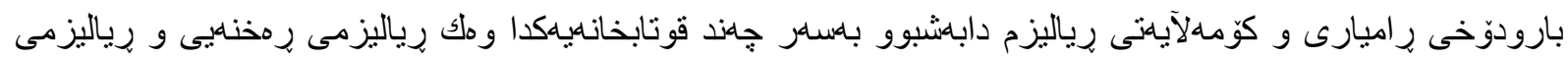

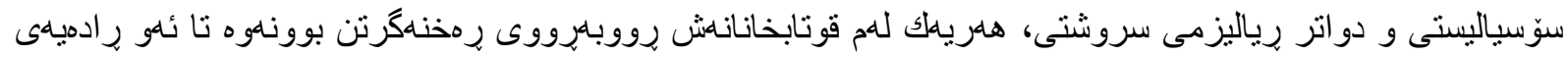

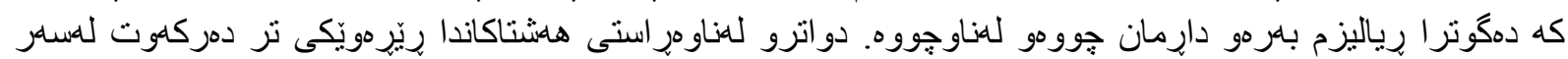

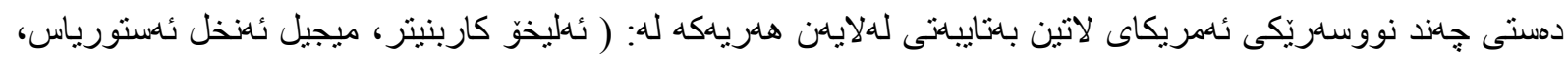

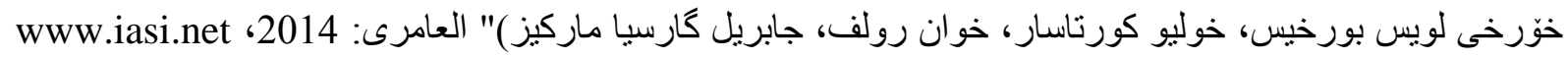

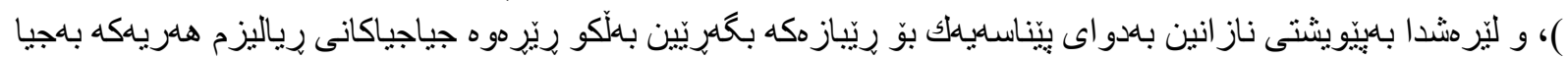

دهناسيّنين.

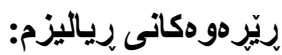

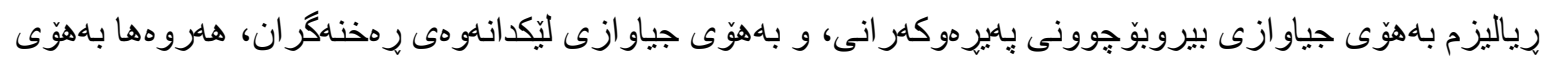

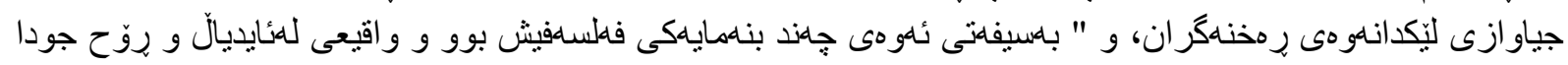

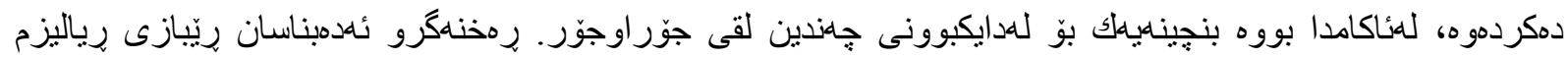

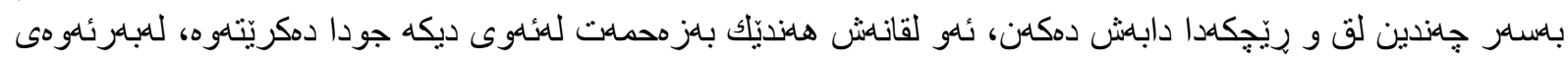

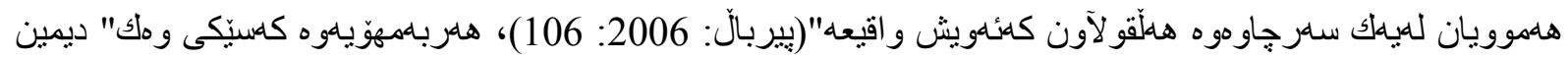

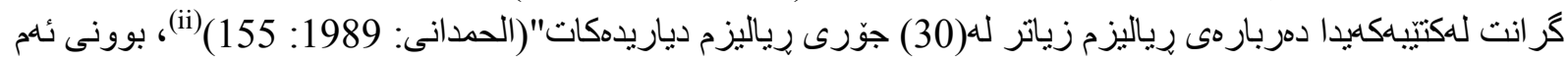

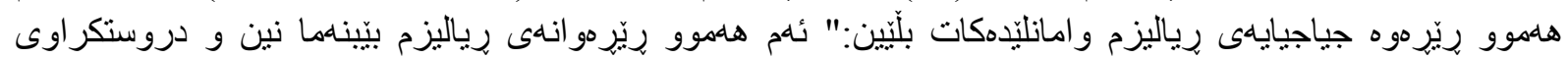

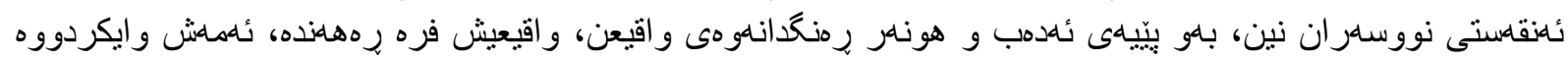

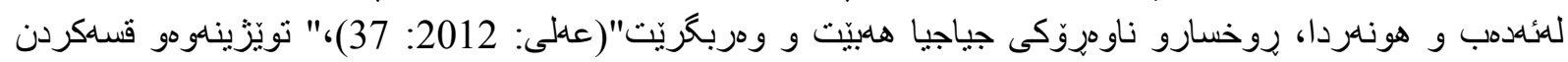

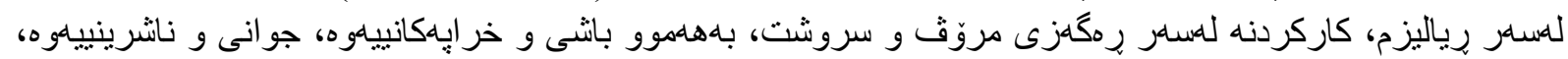

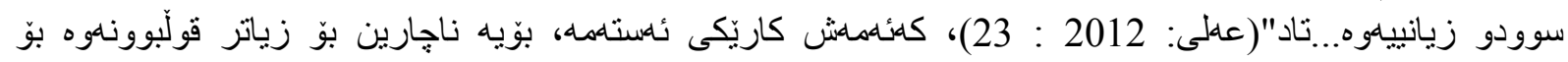

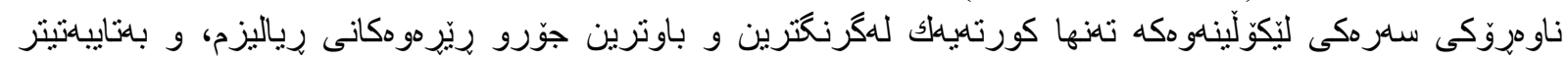

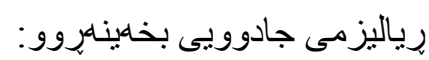

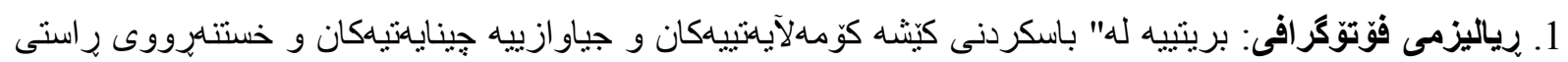

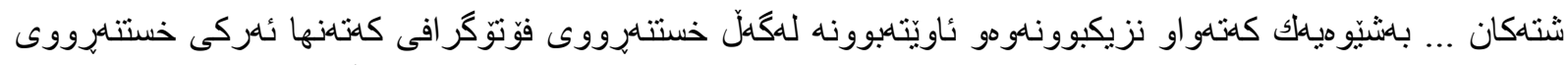

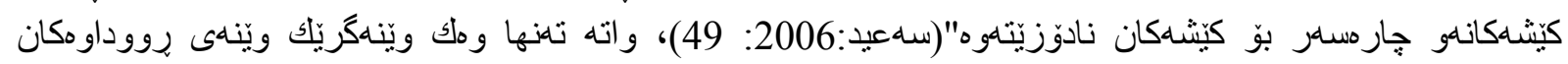
دمكريّت. 


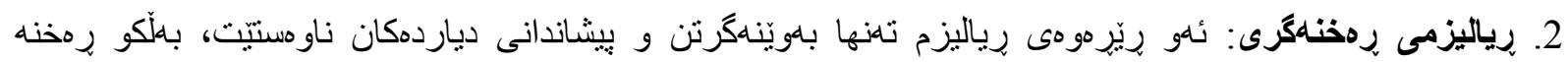

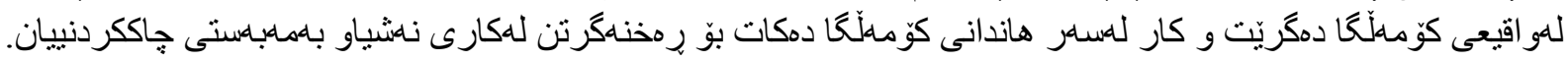

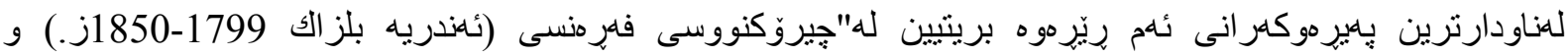

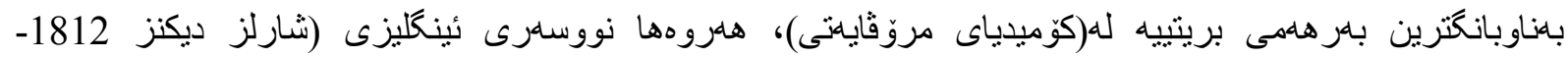

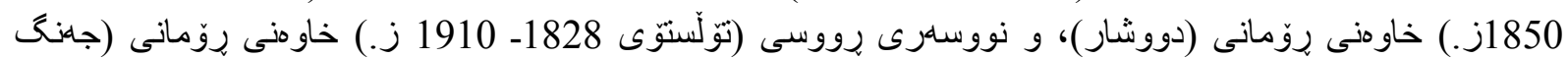

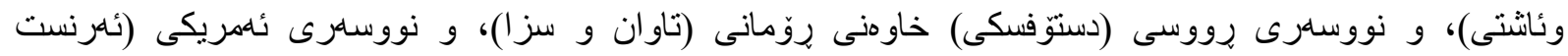

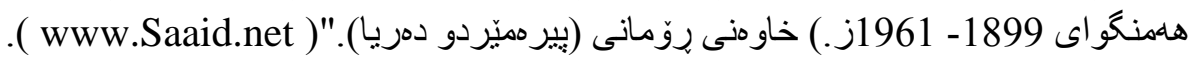

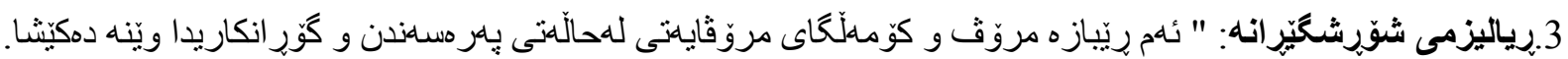

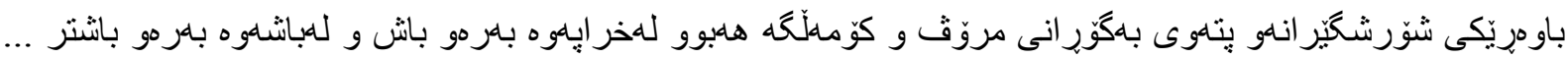

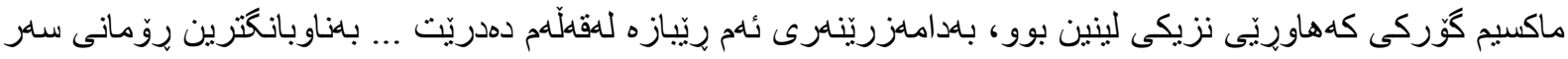

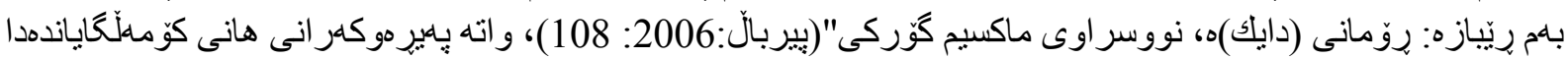

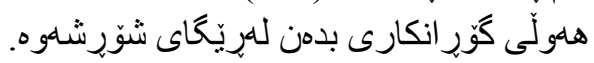

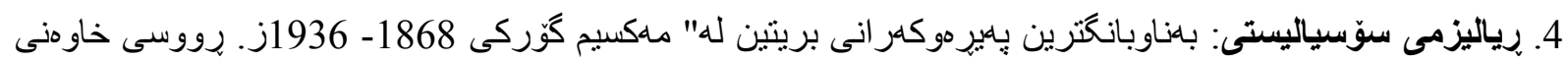

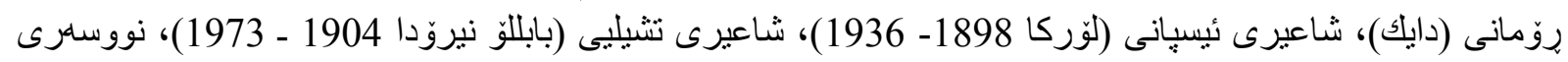

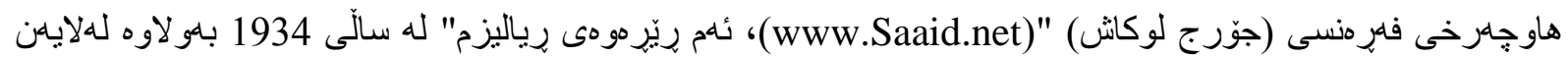

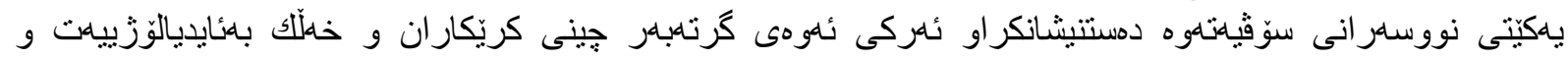

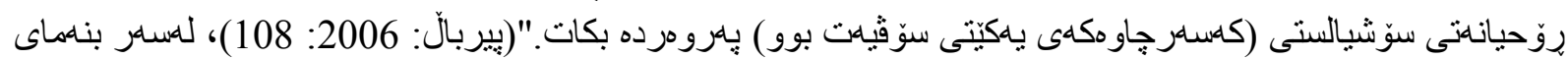

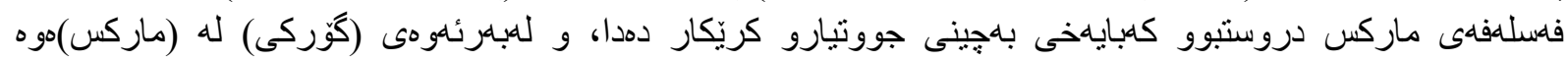

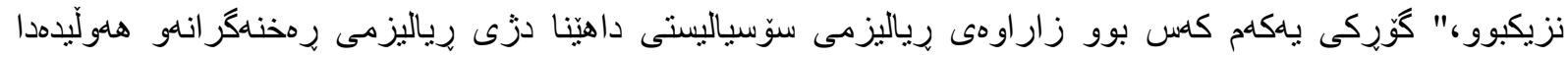

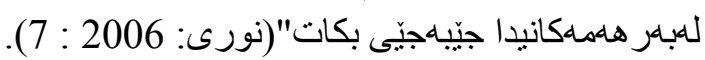

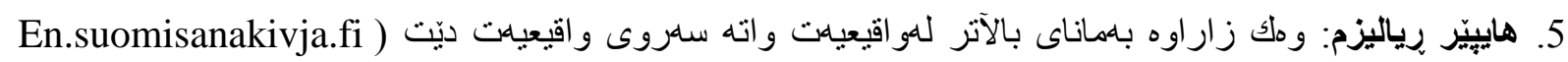

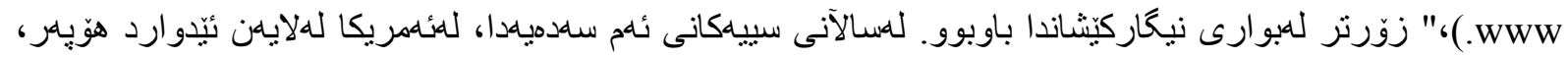

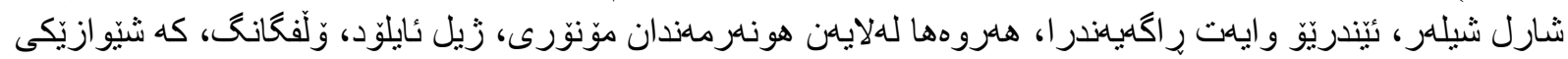

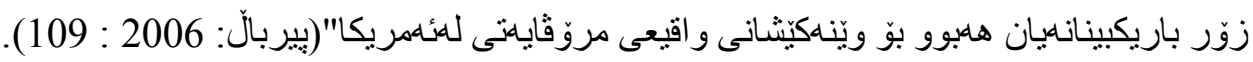

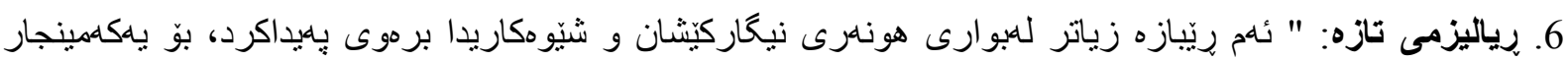

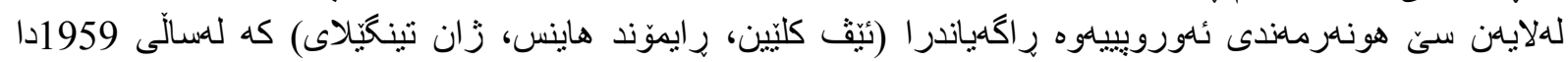

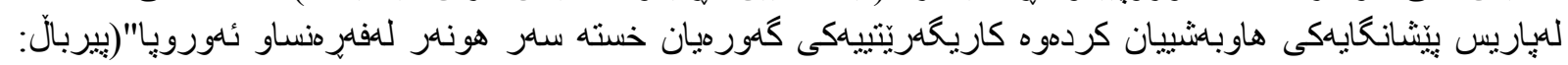

.) 2006

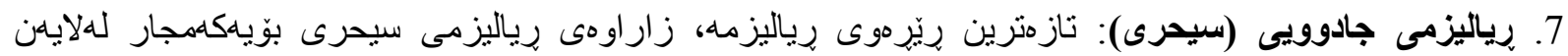

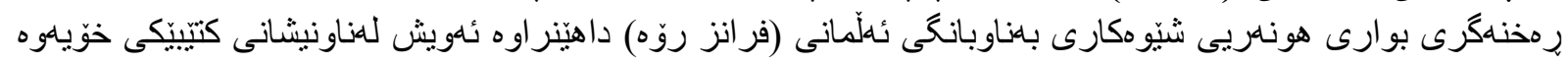

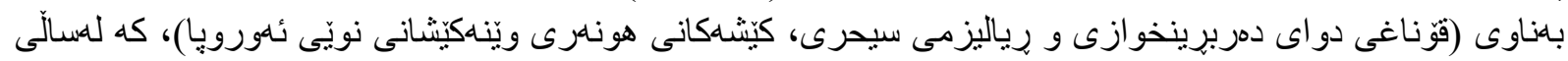

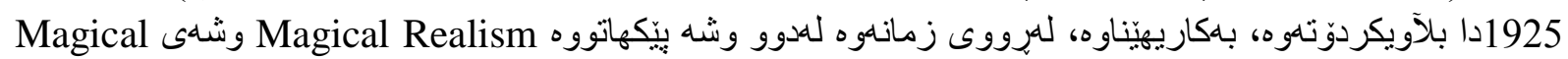

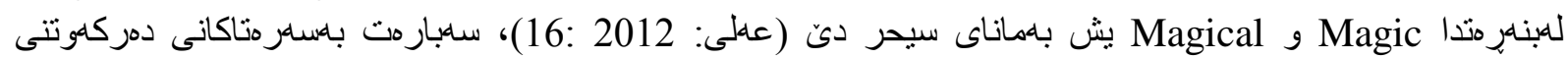

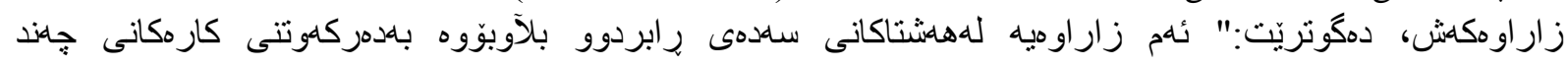

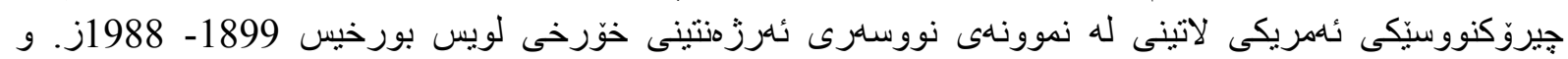

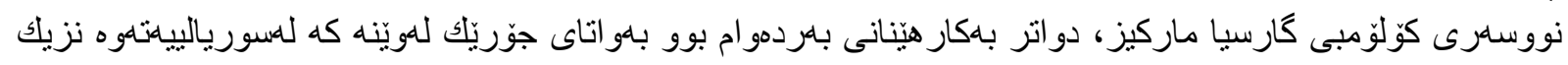

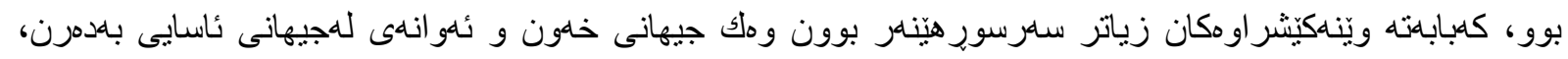

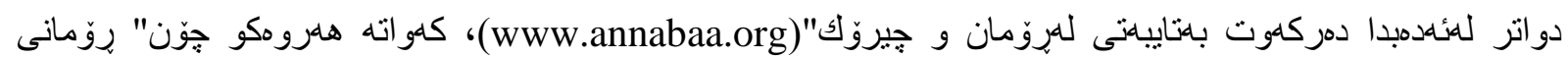

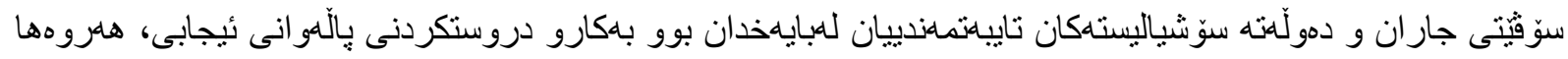

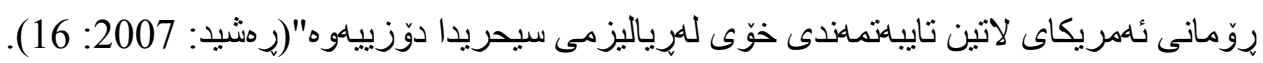




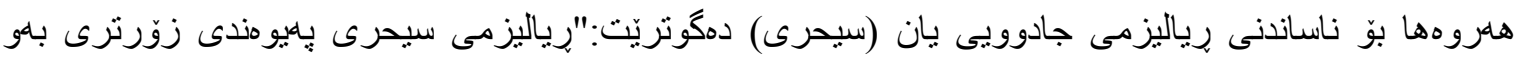

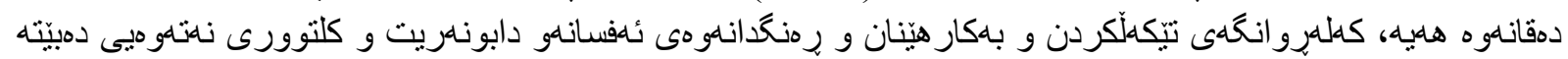

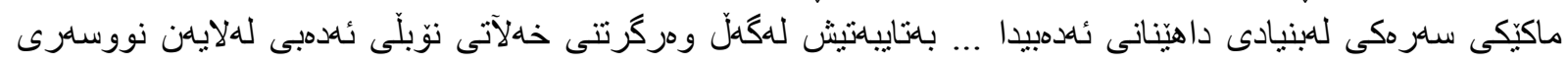

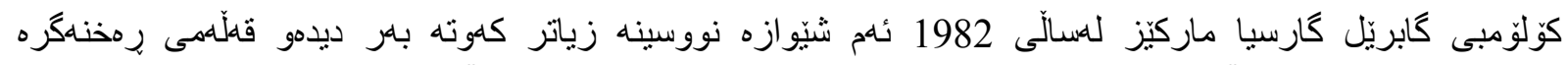

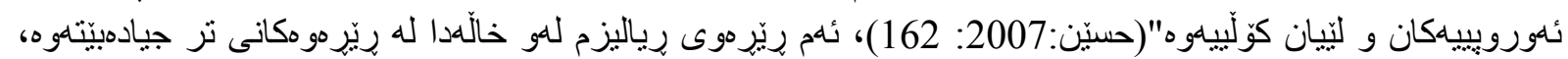

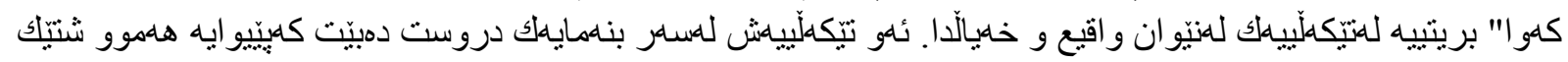

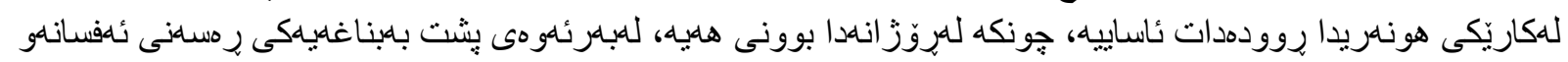

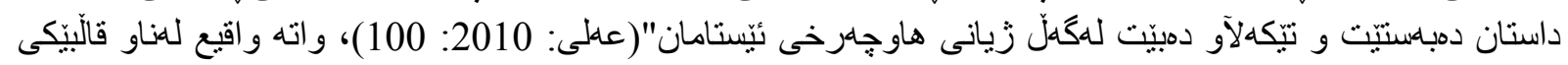
خميالّ و فهنتازيادا دادهيَّزيت.

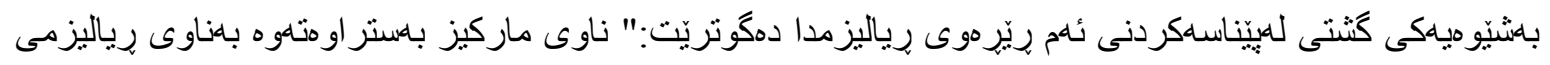

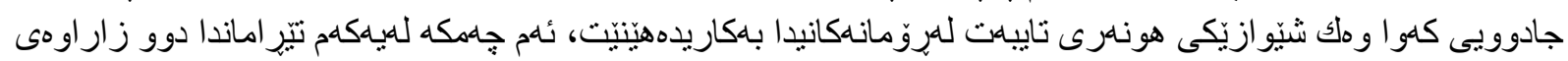

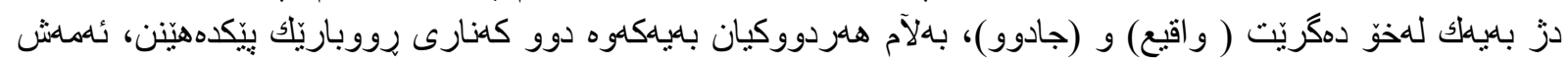

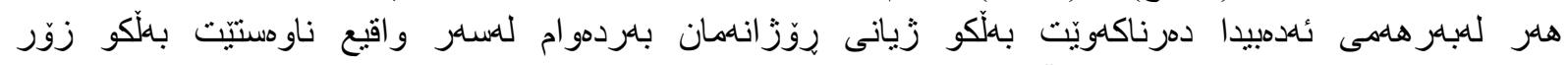

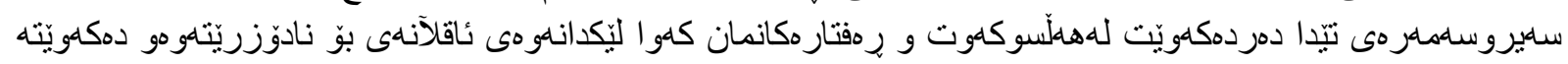

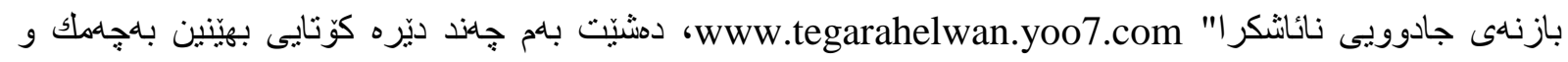

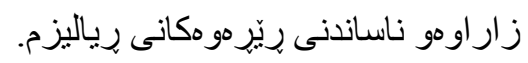

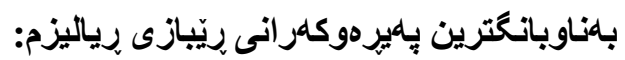

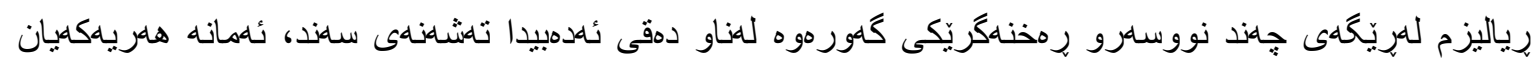

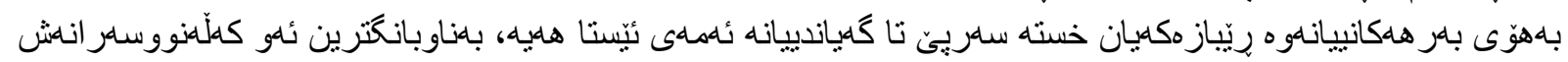
بريتى بوون له به: بهون

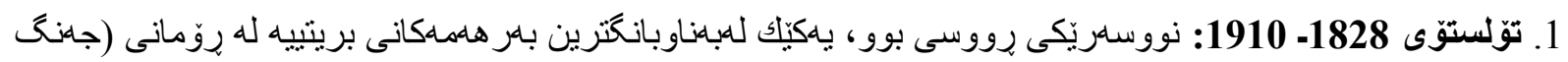

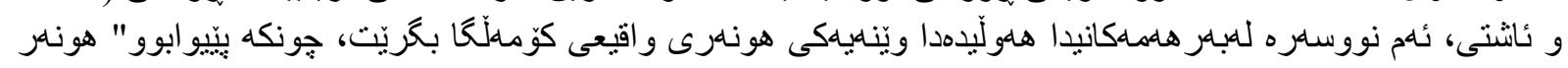

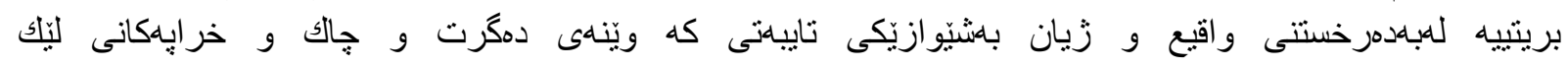

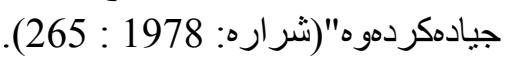

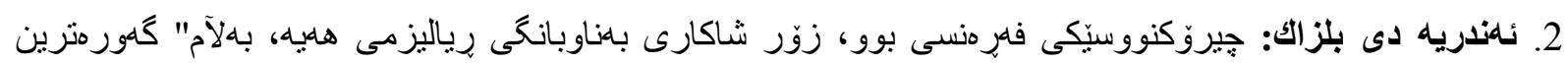

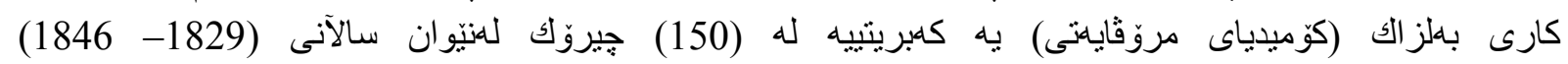

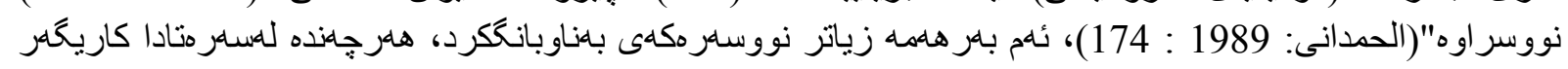

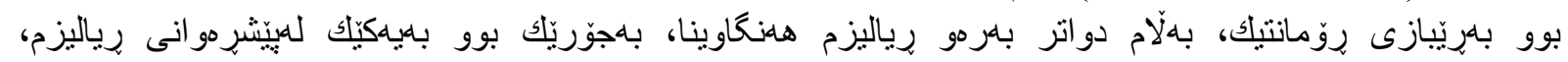

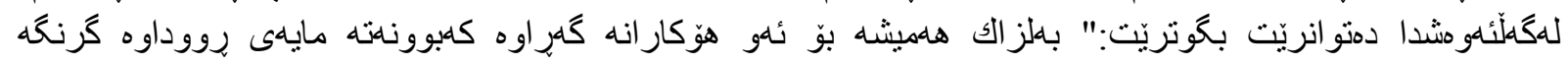

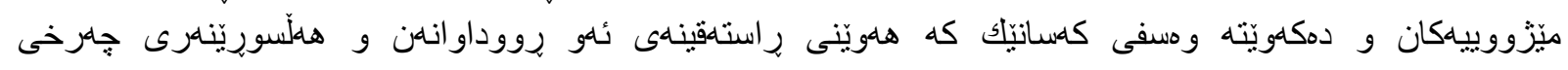

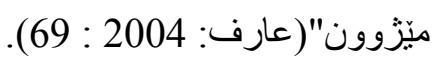

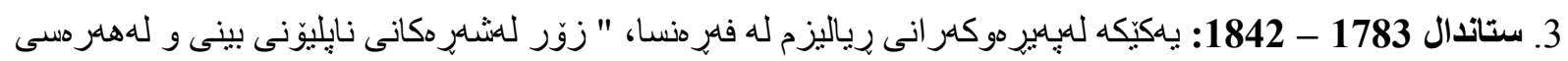

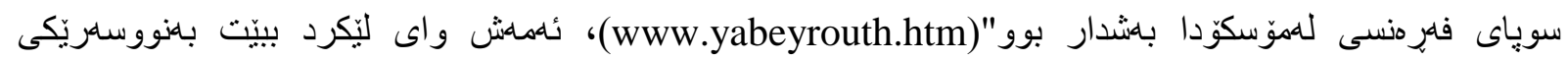

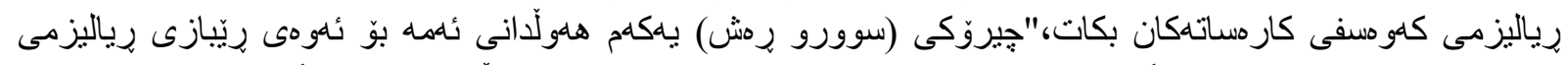

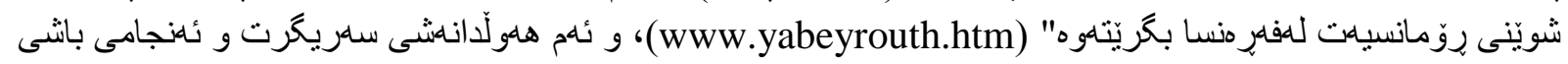

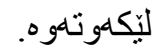

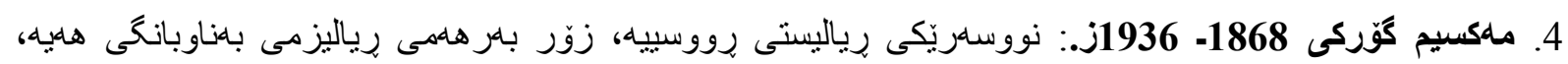

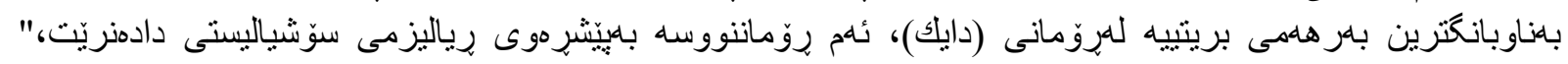




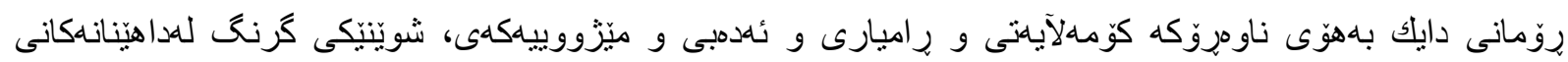

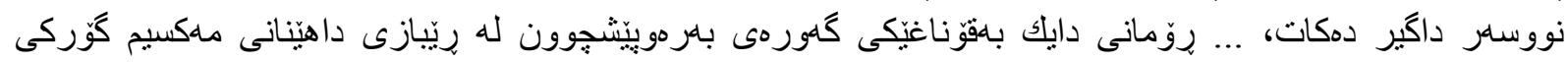

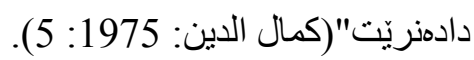

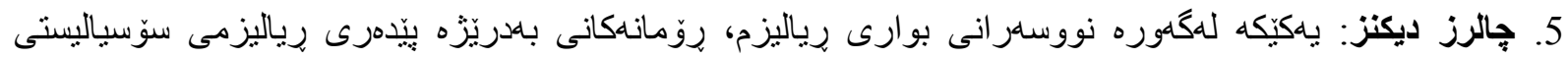

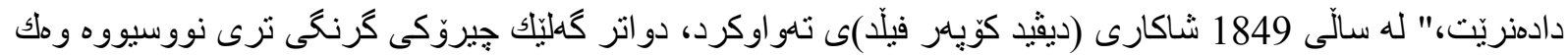

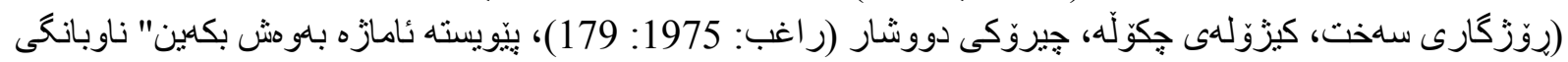

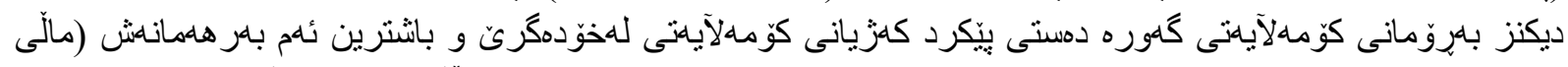

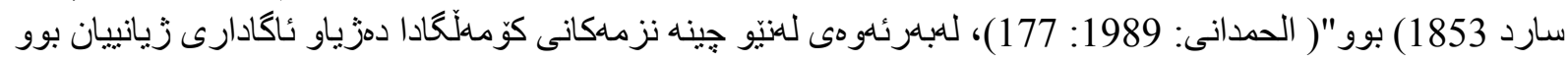

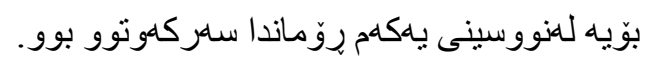

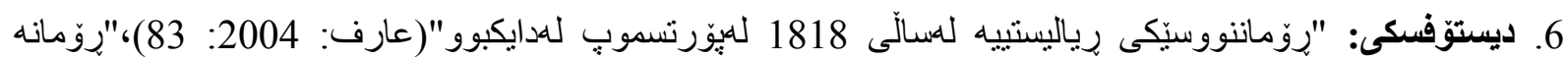

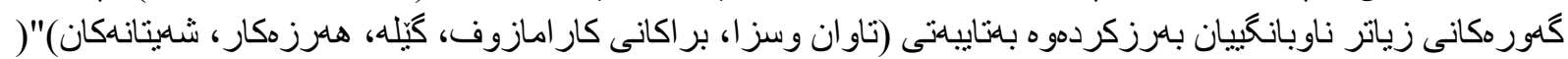

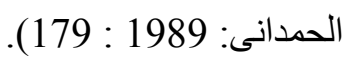

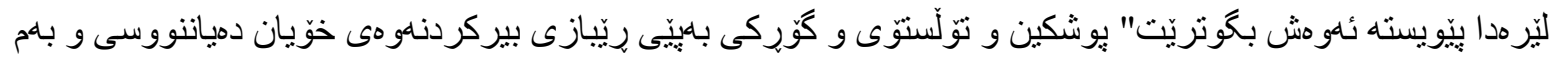

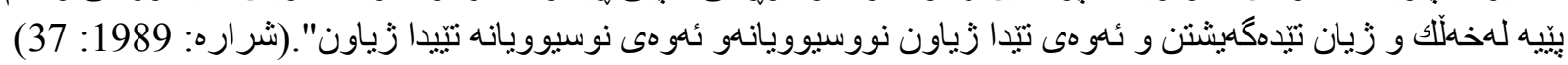

\section{بالشى دووهم \\ رياليزم و روّمانى كوردى}

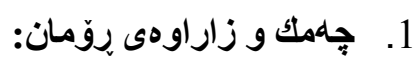

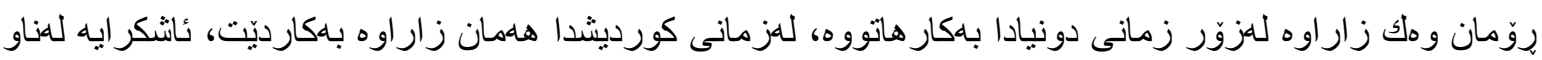

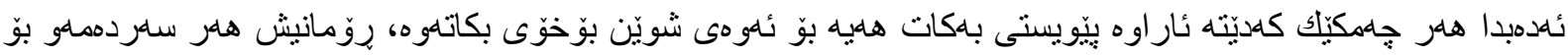

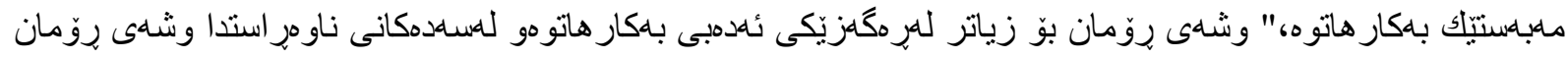

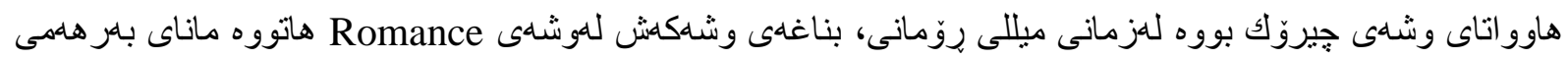

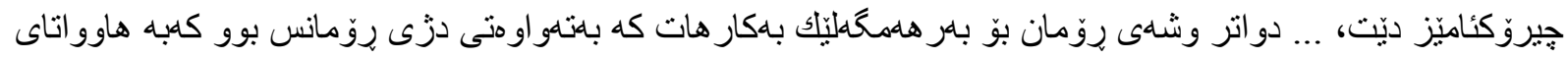

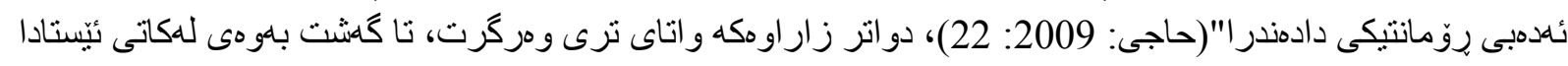

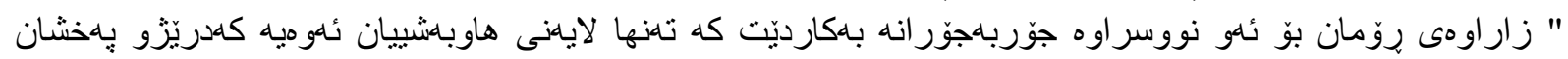

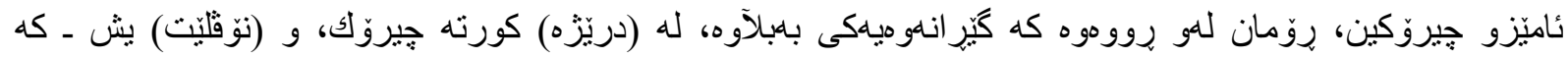

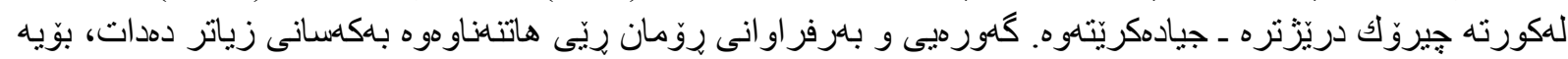

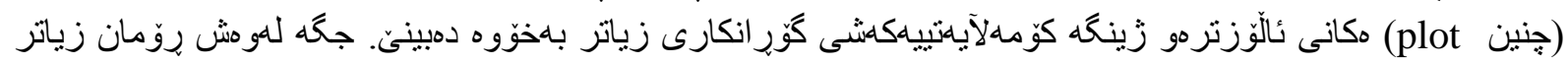

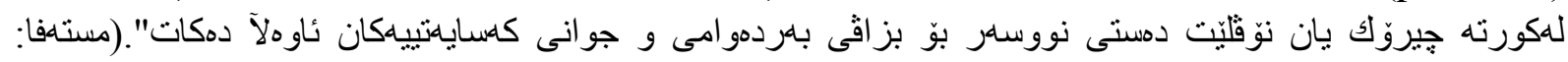

.) 2008

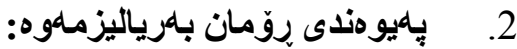

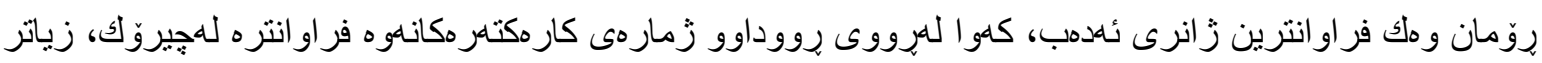

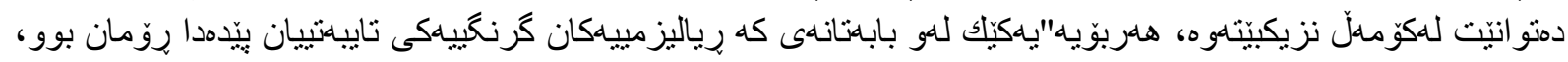

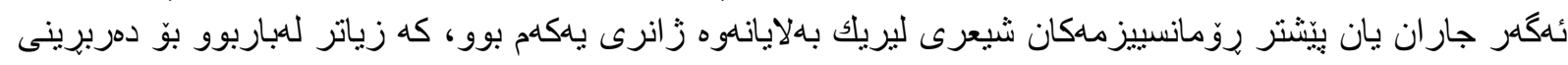

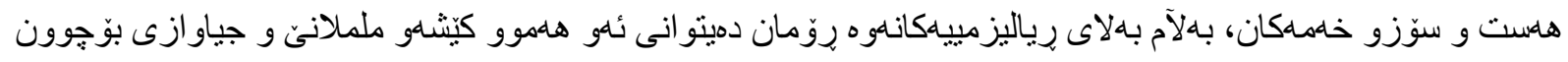

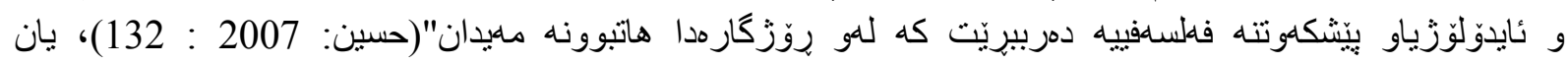




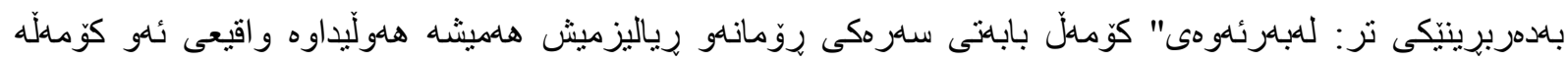

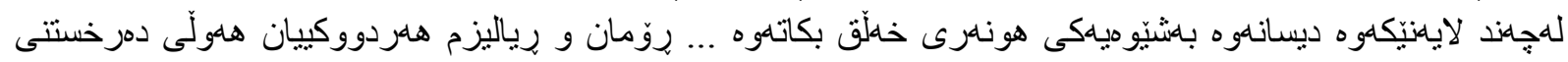

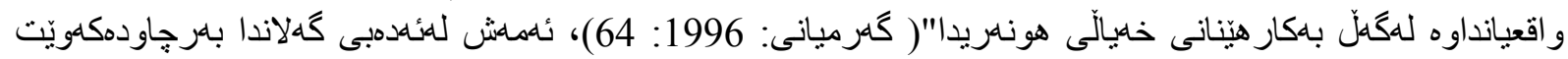

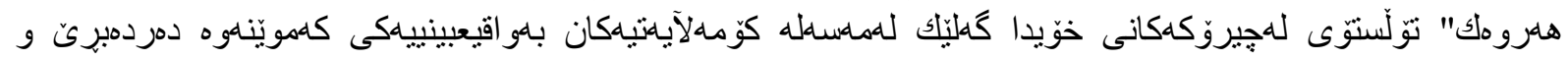

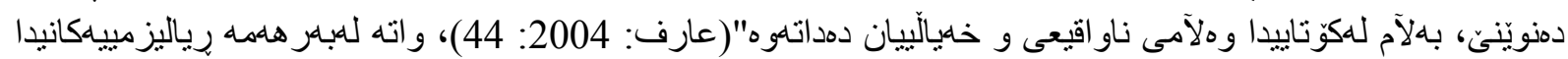

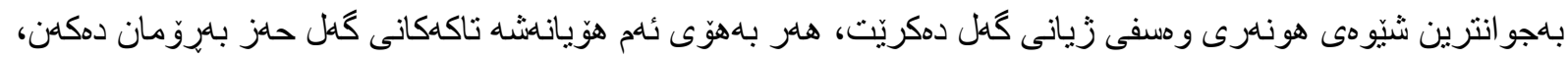

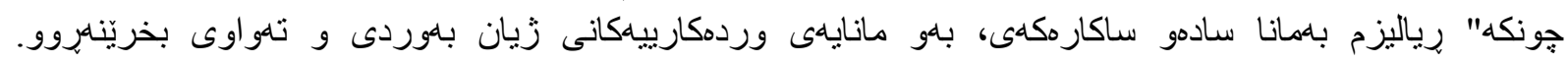

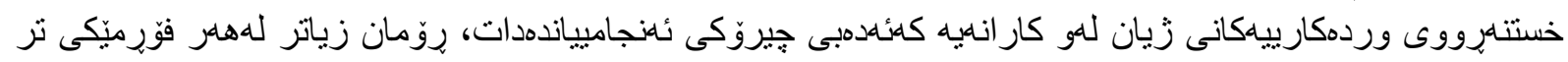

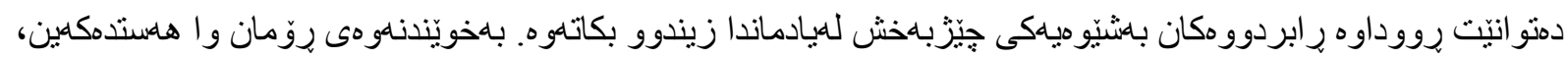

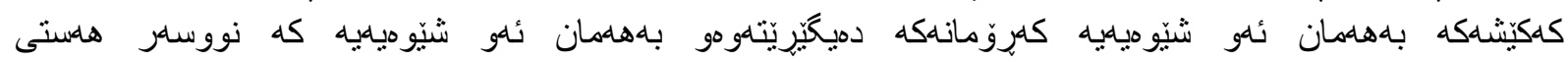

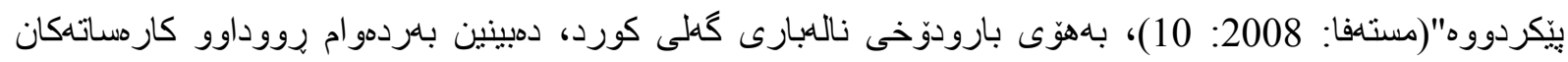

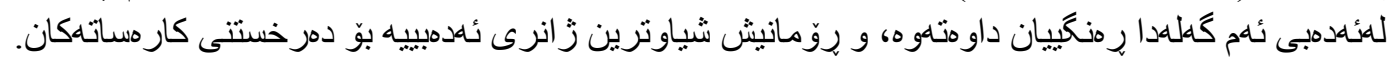

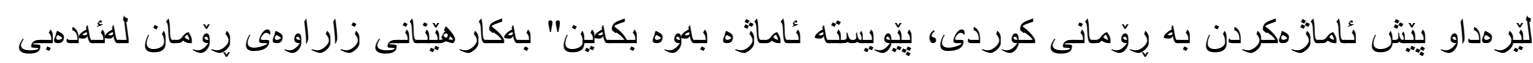

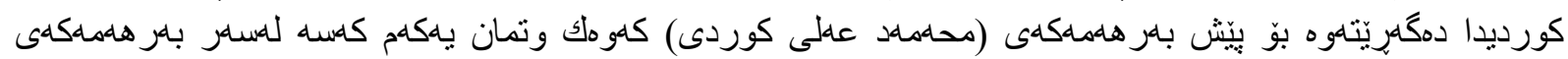

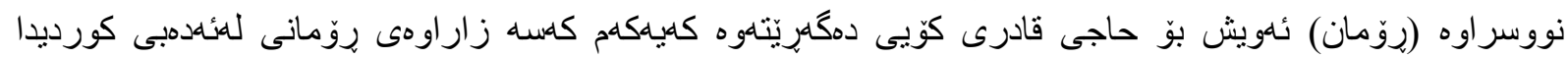

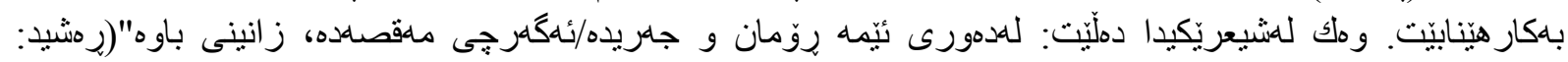

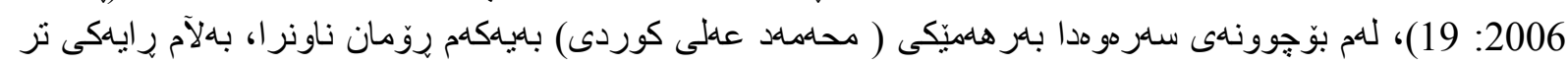

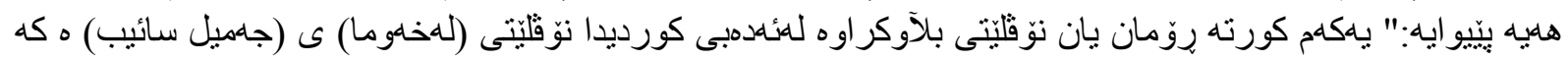

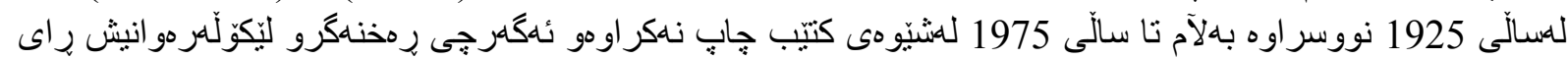

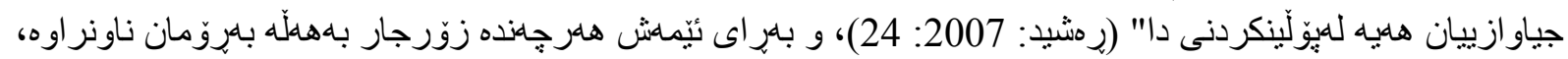

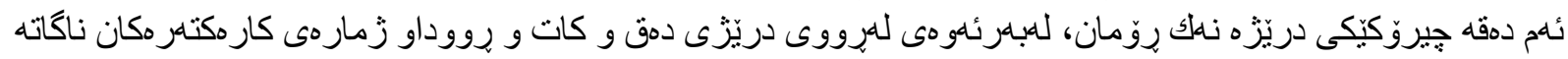

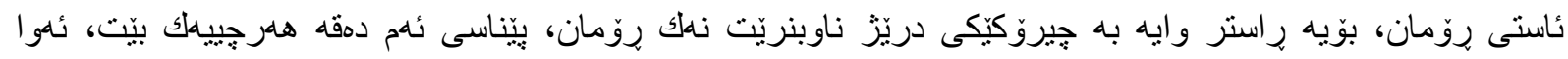

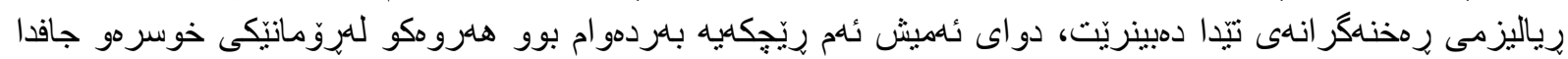

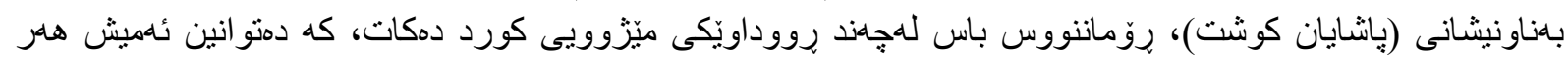

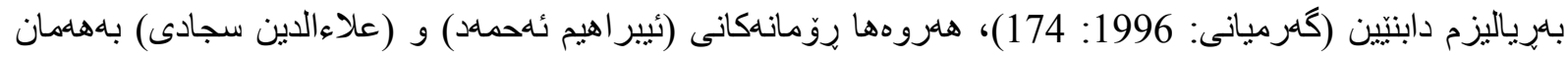

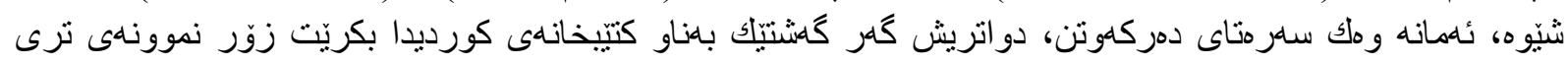

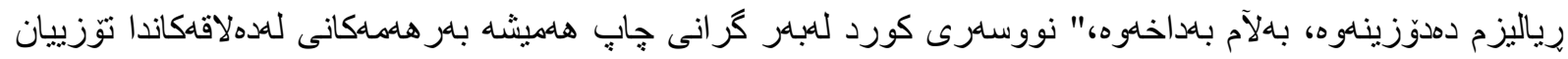

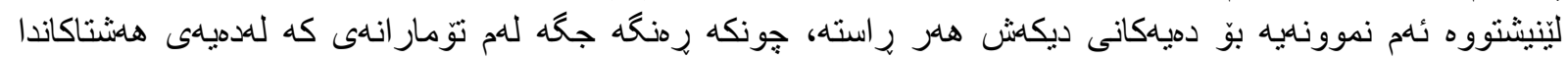

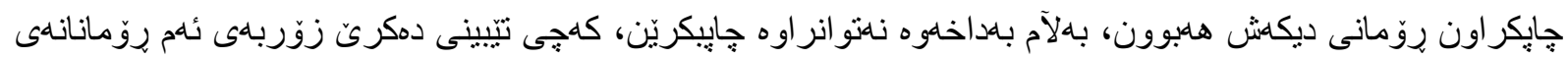

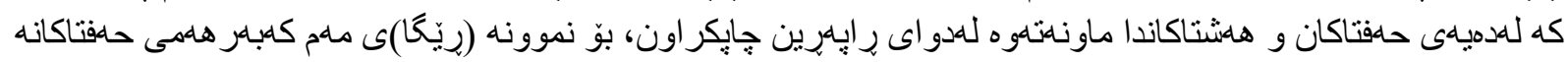

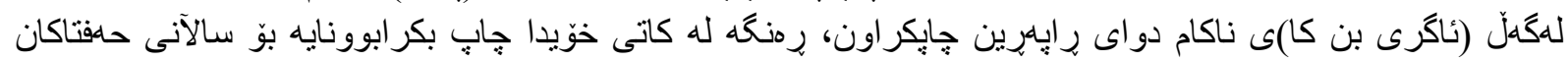

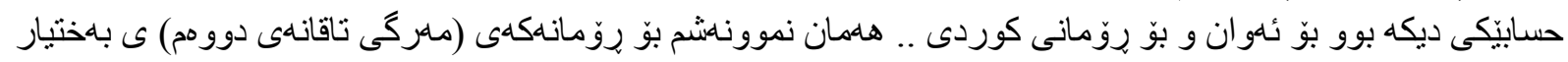

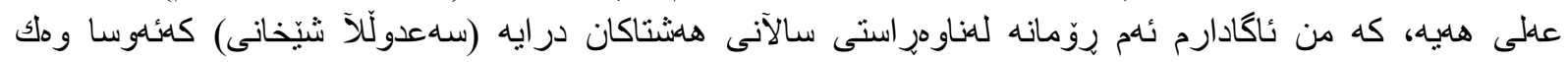

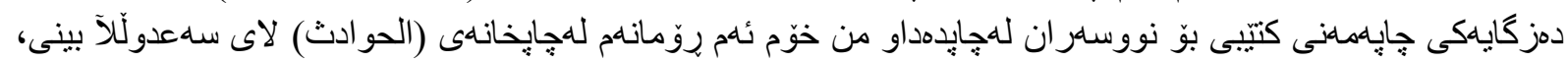

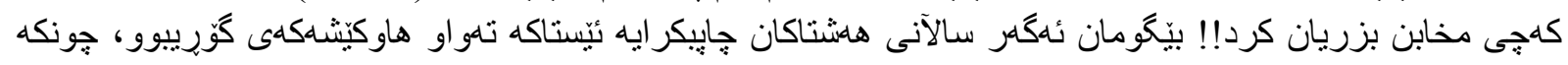

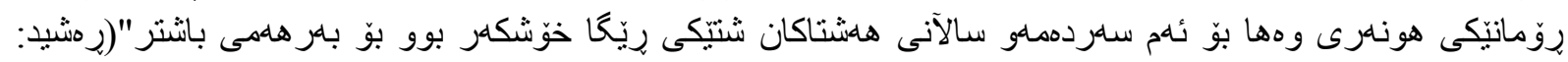

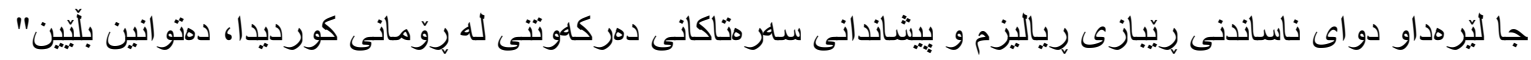

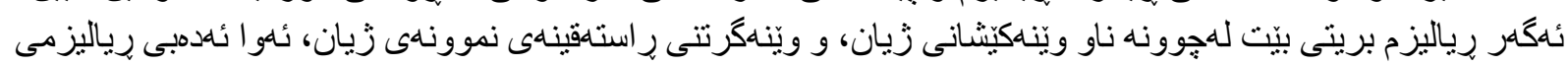

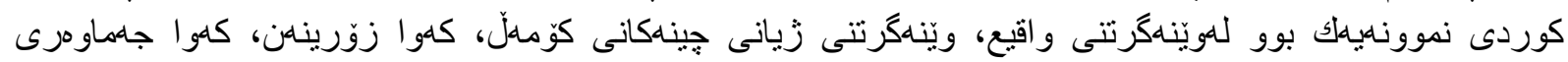

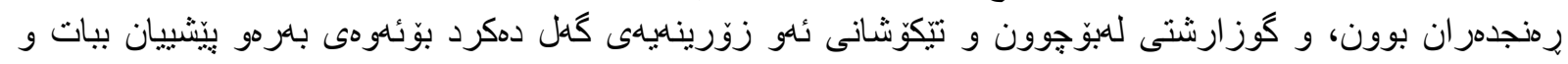

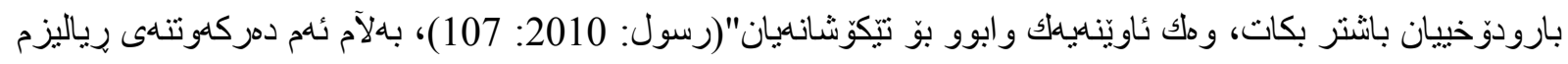




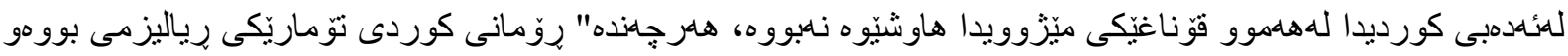

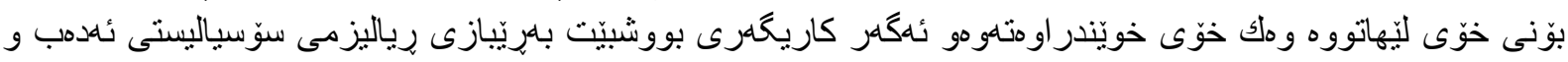

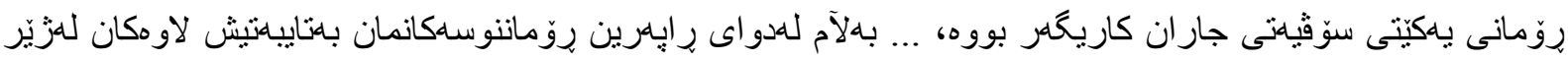

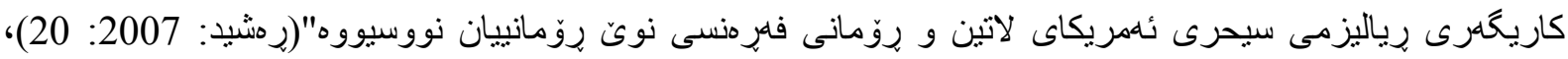

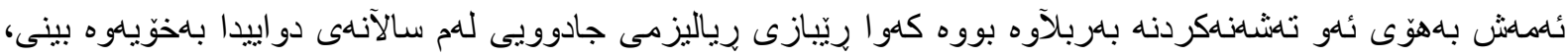

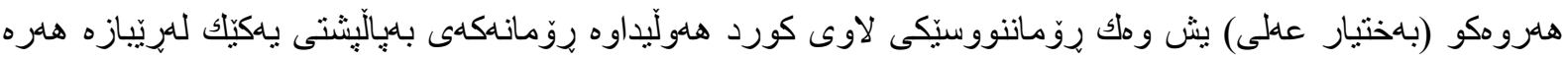

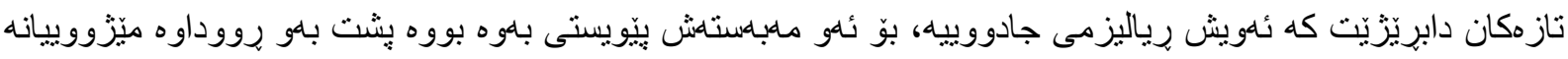

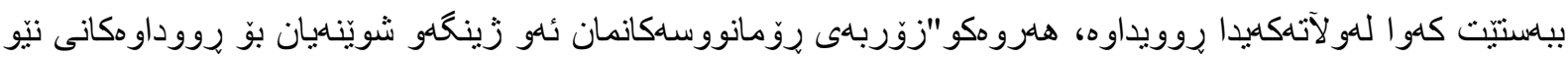

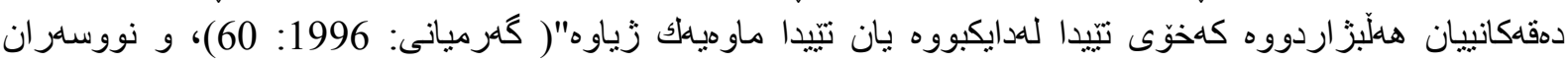

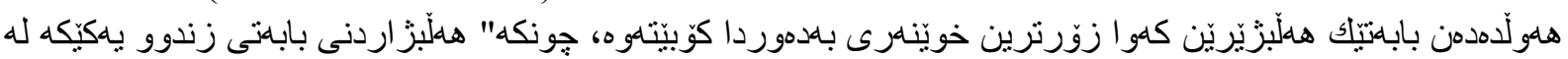

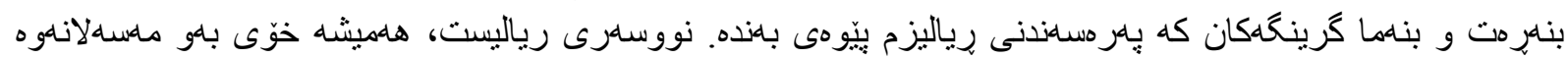

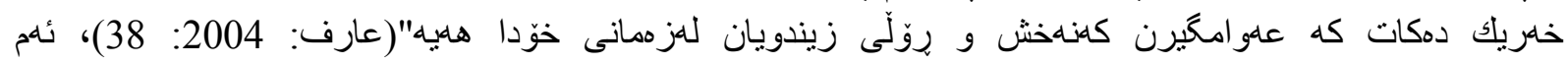

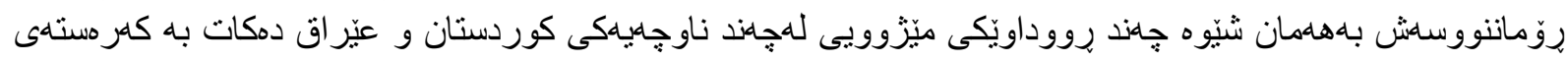

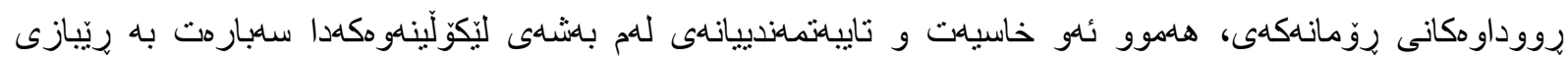

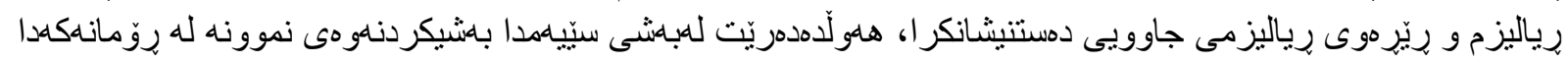

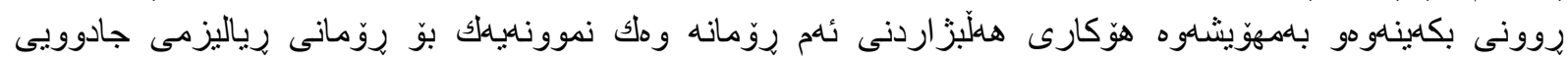

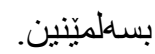

\section{باهشى سيّيهم \\ رياليزمى جادوويى للمِوَمانـكهدا}

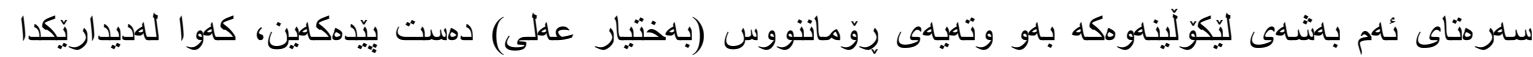

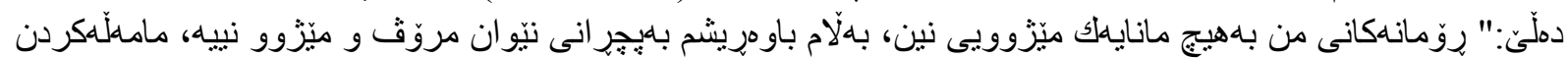

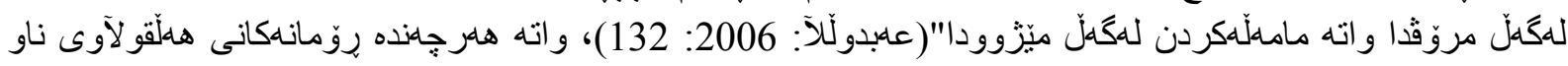

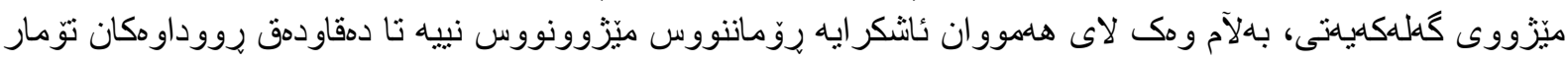

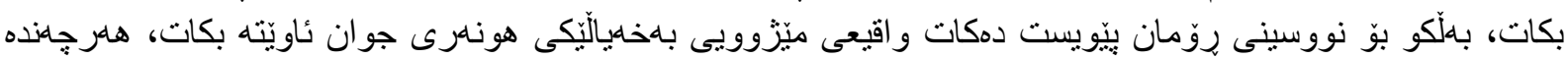

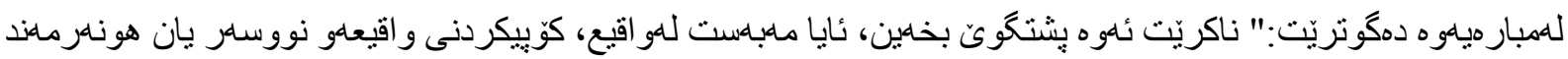

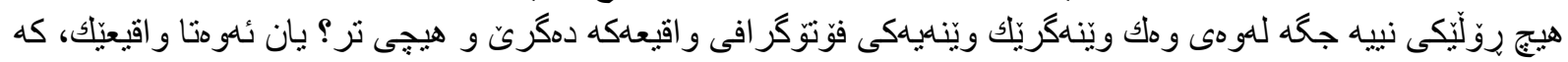

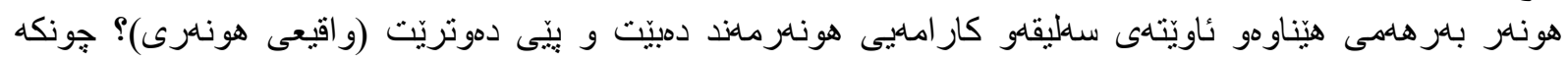

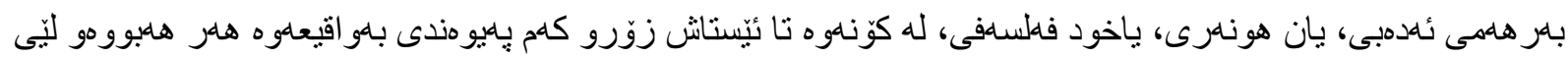

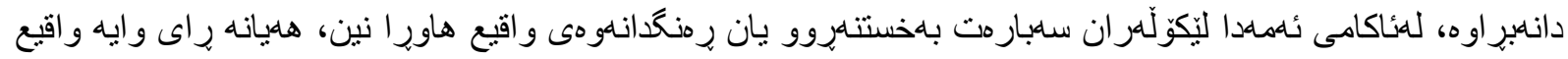

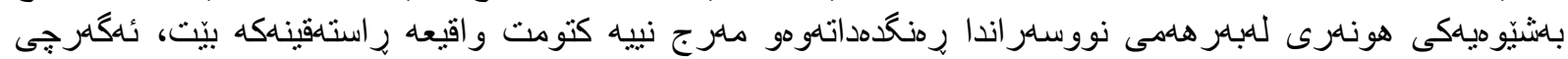

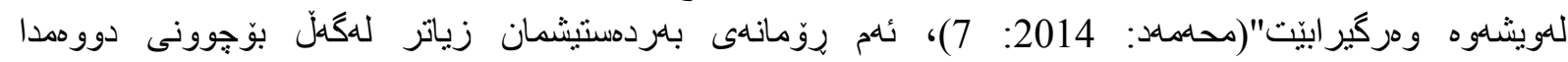

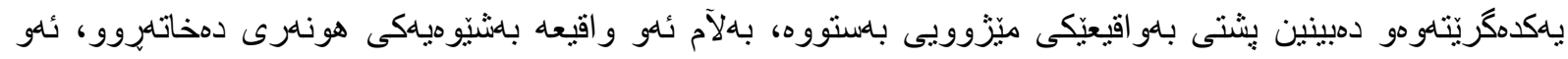

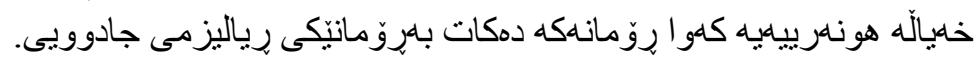

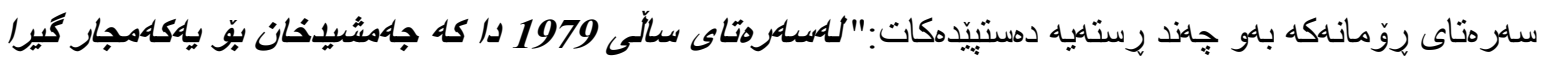

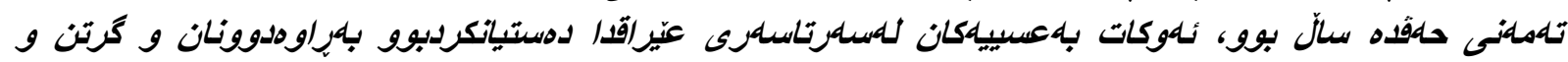

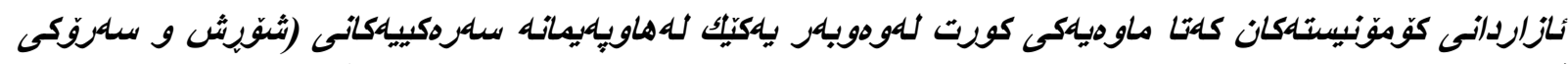

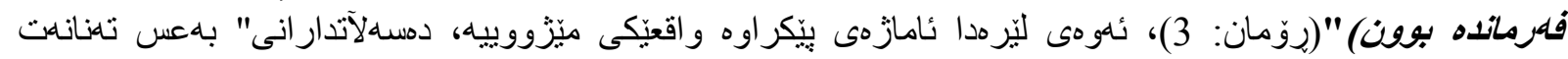

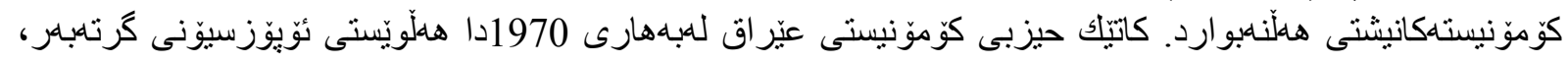




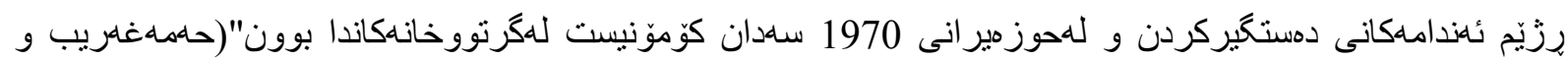

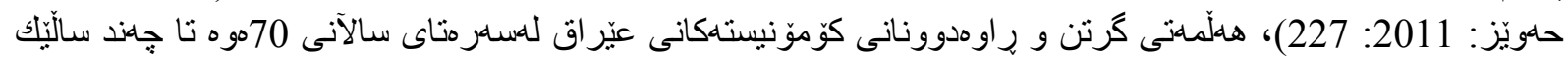

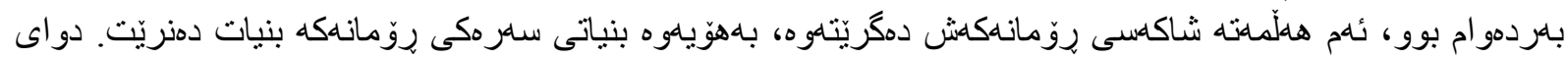

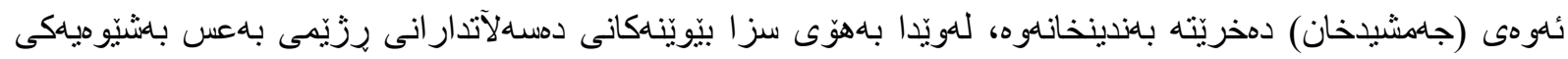

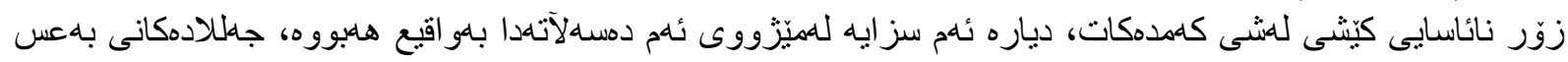

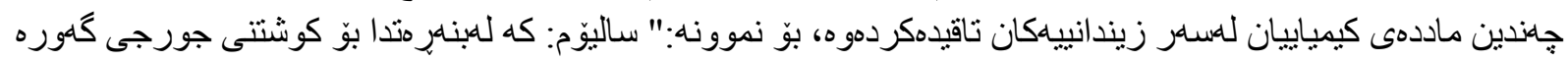

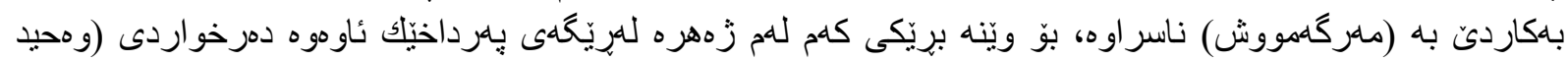

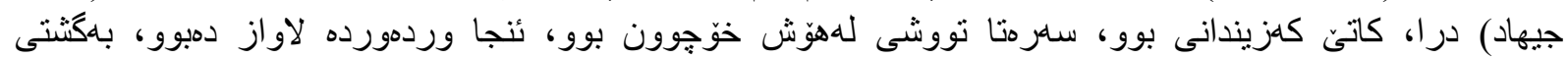

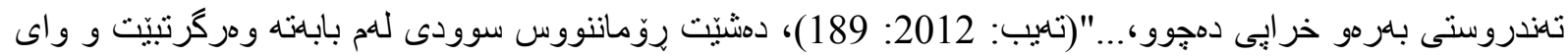

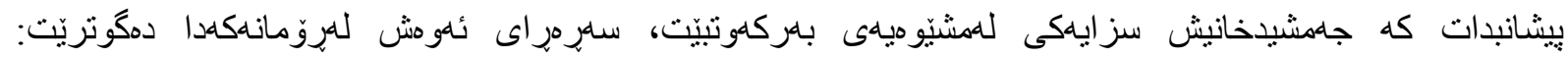

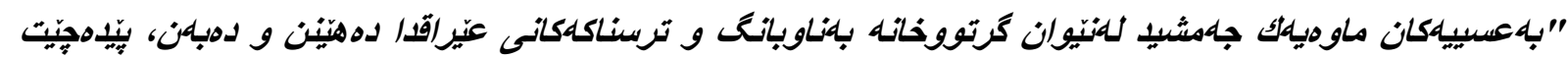

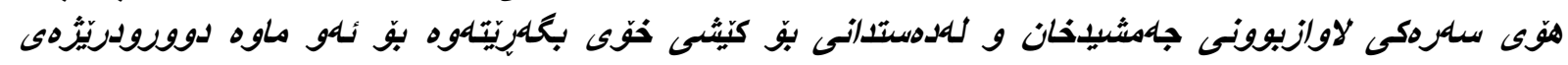

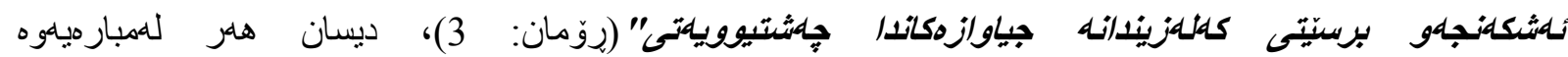

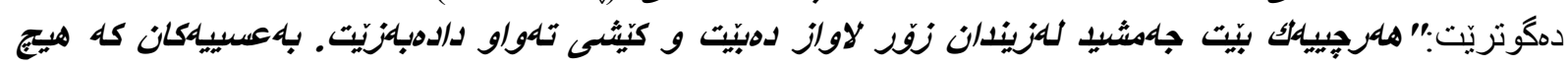

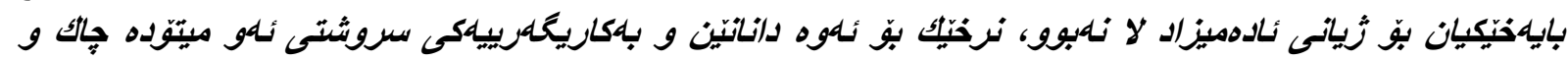

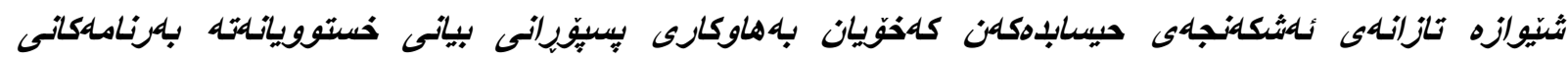

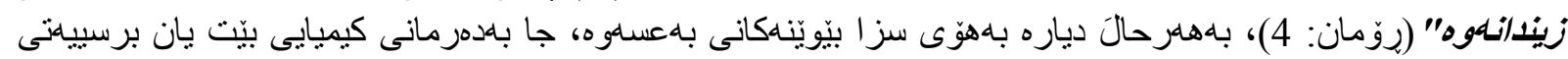

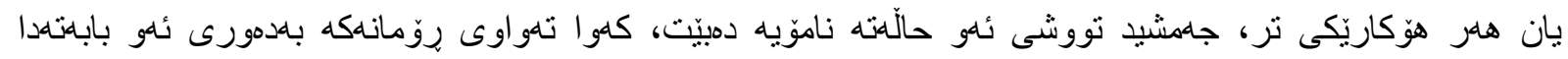

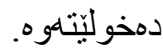

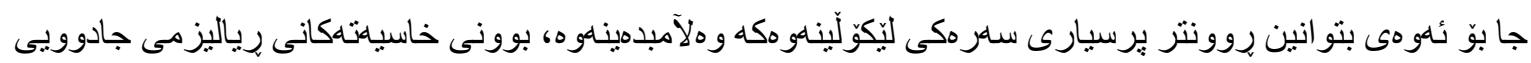

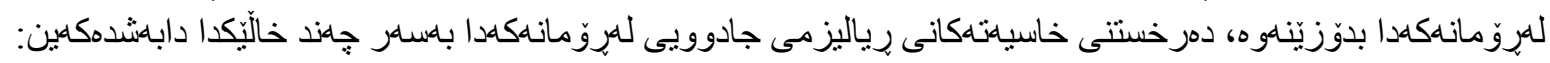

\section{1}

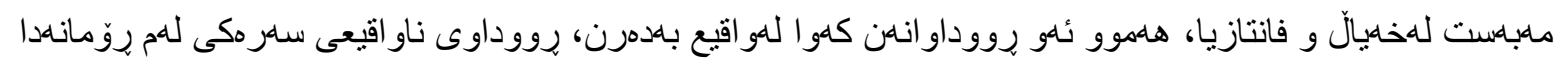

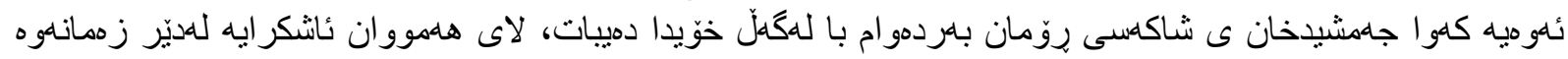

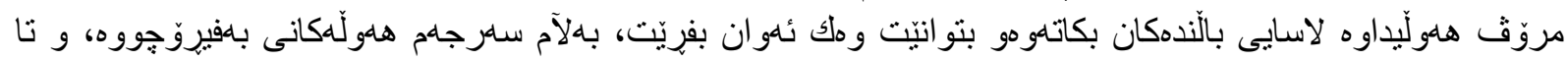

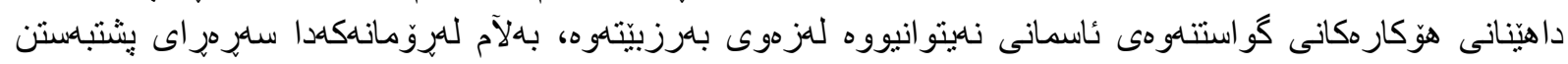

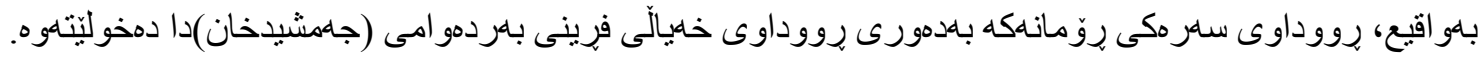

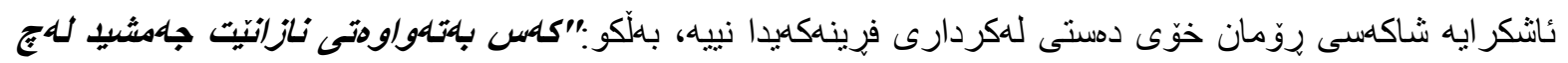

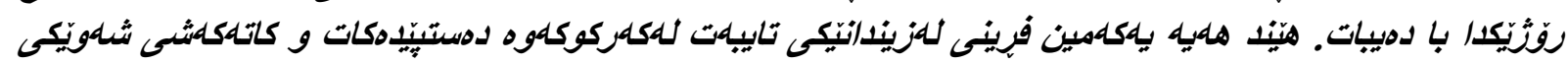

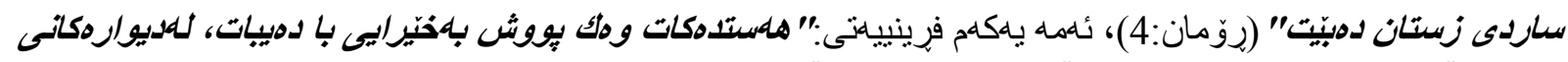

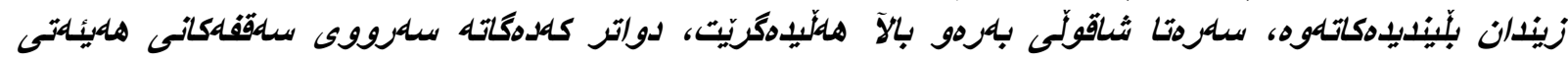

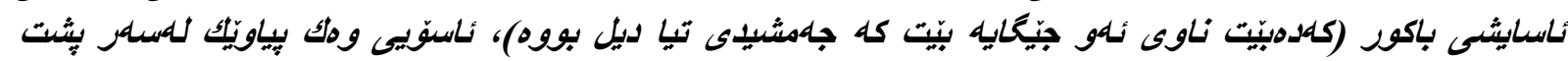

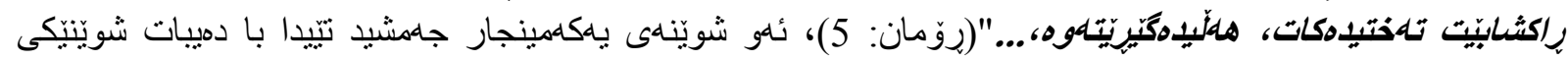

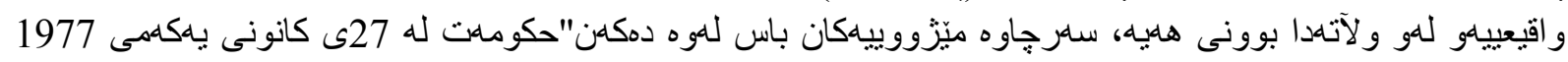

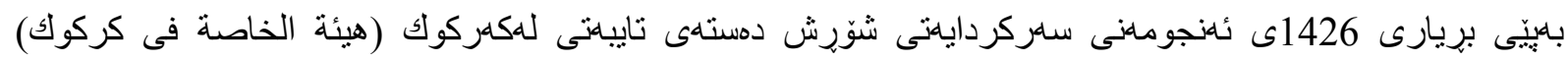

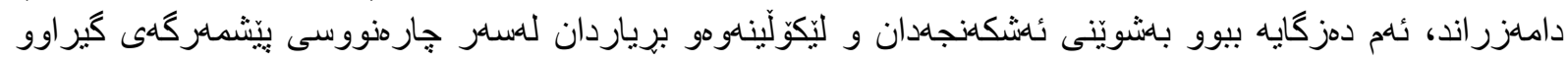

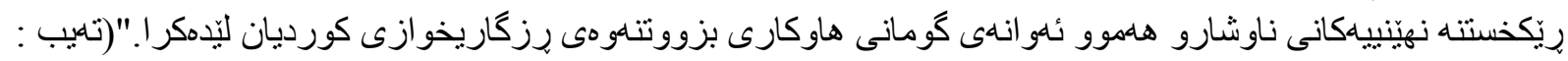

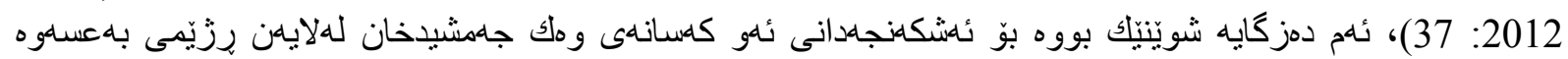

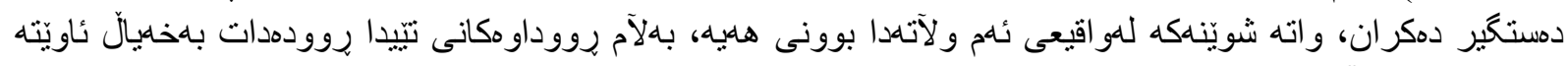

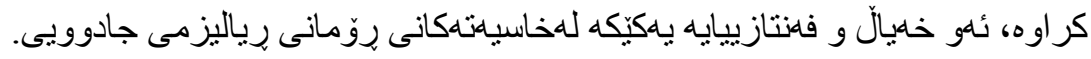




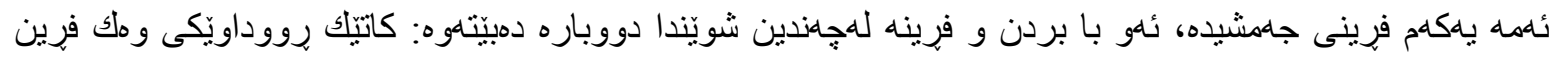

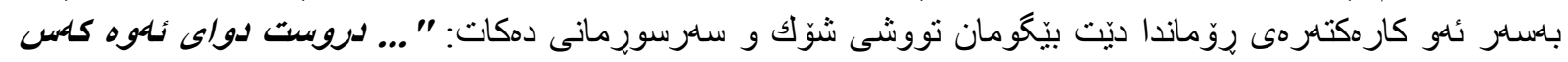

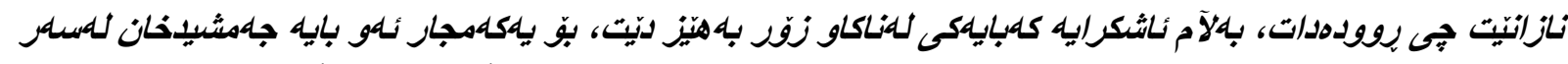

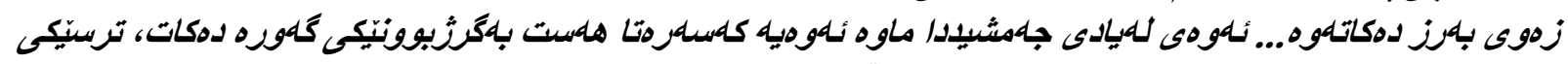

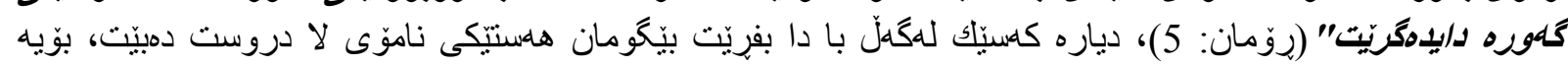

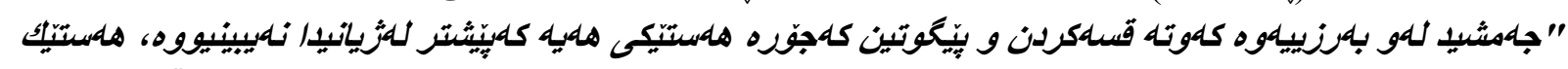

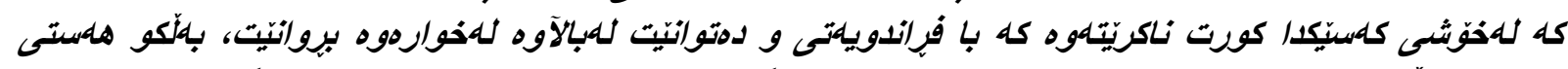

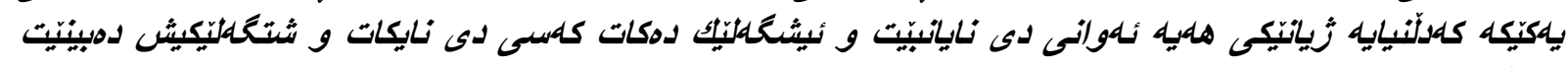

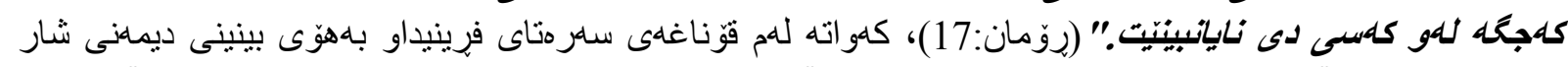

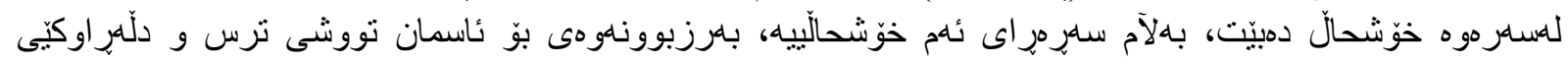

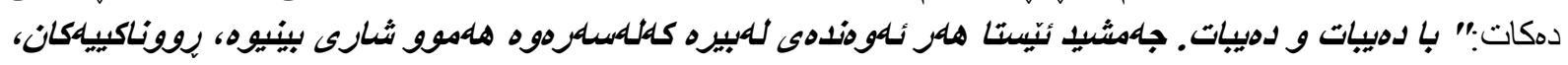

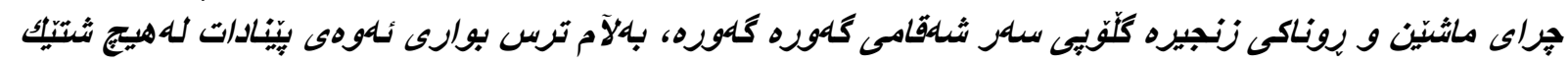

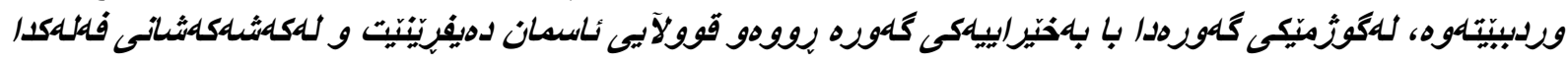

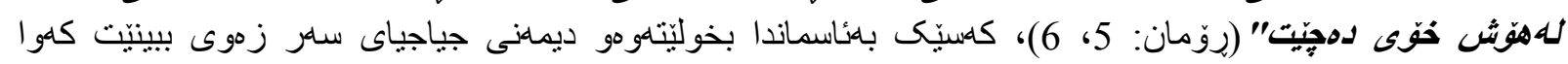

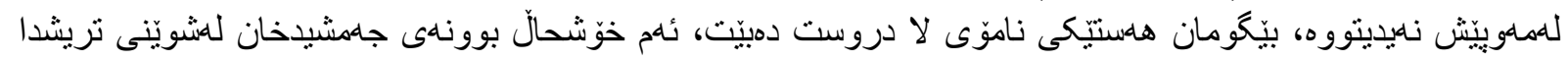

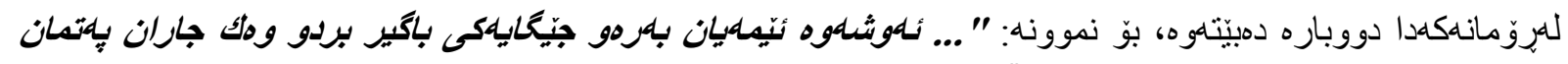

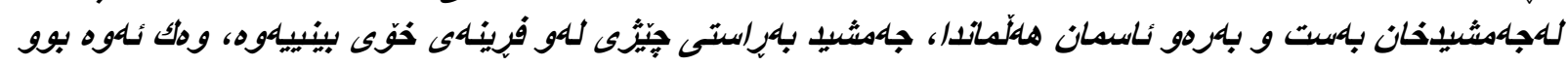

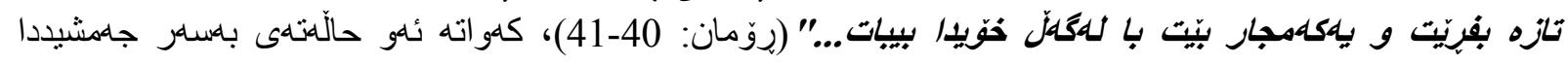

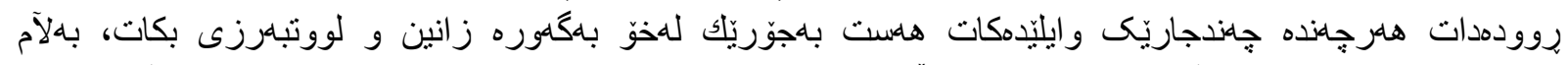

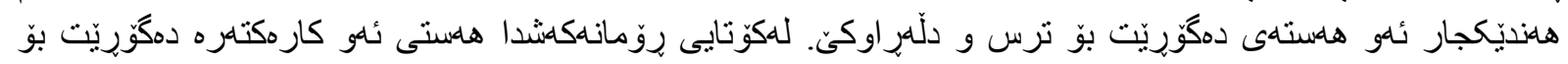

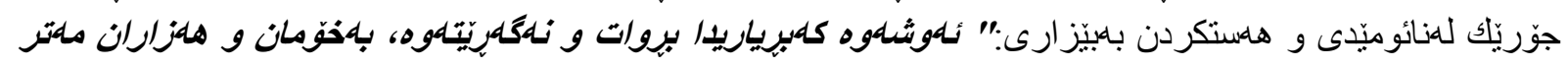

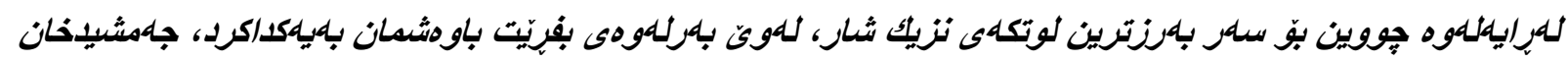

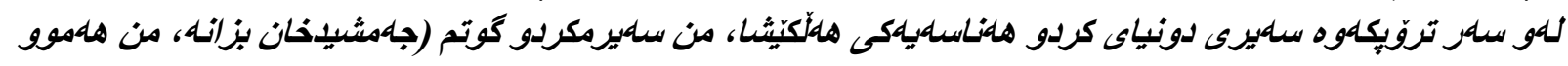

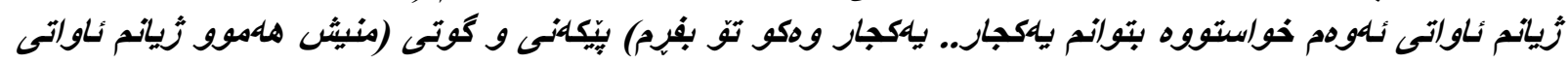

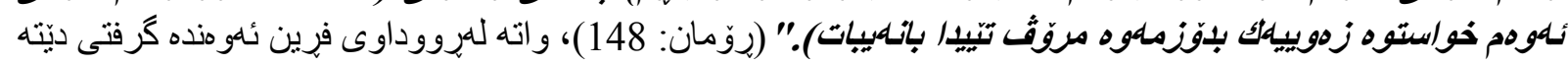

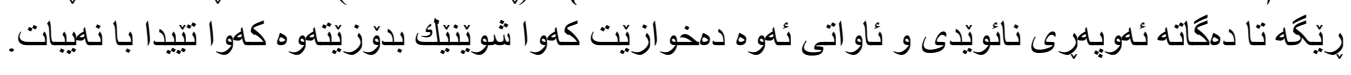

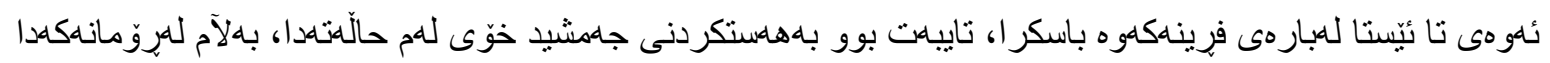

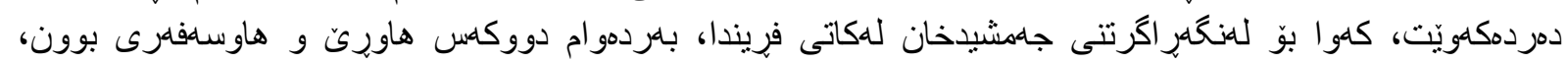

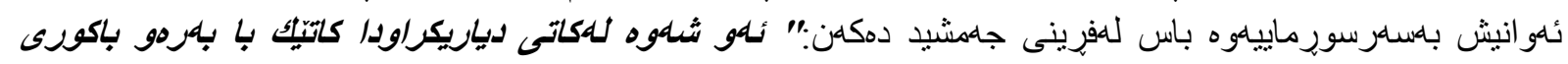

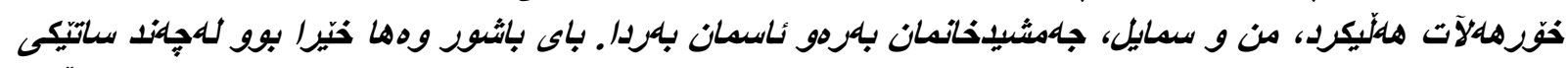

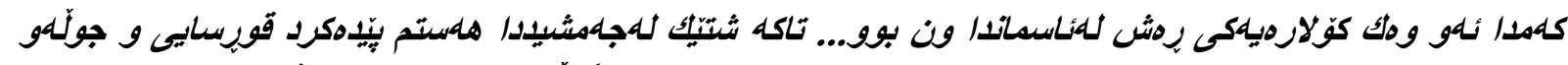

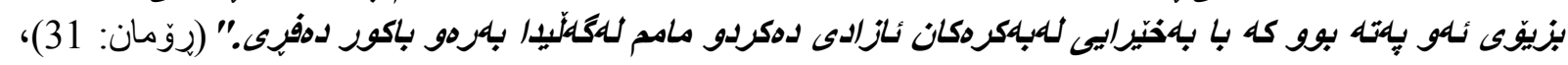

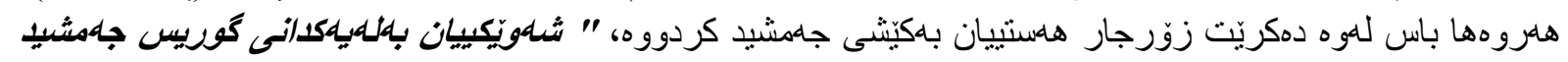

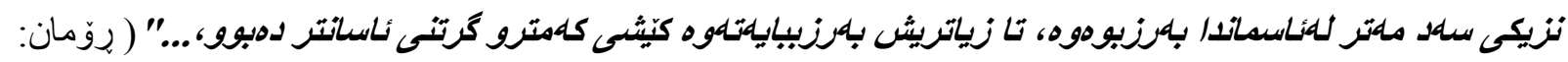

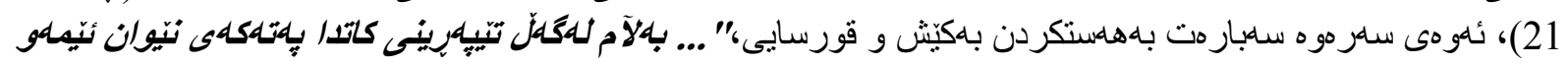

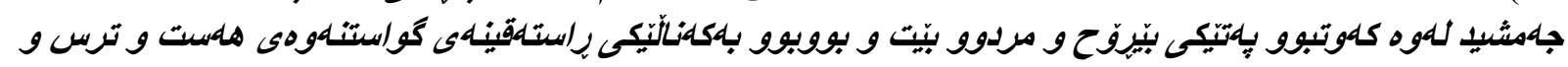

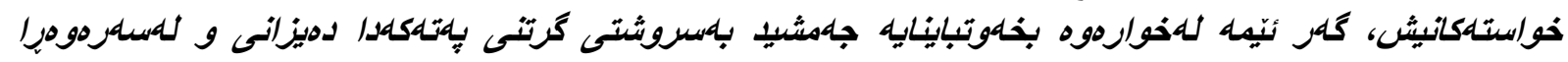

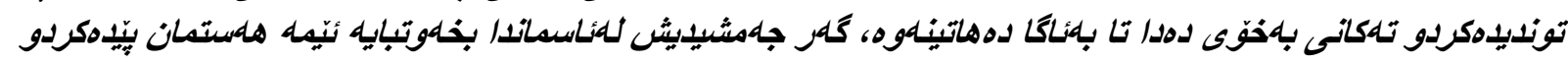

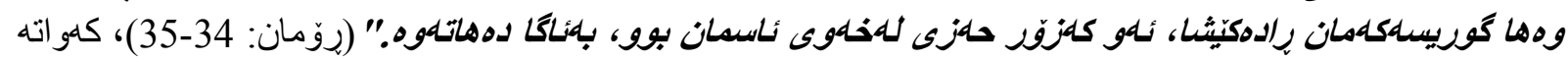

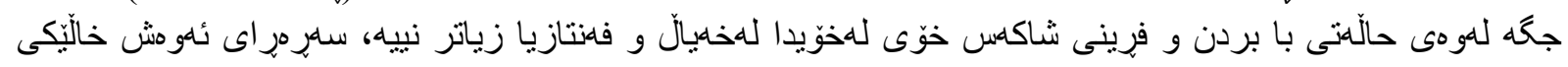

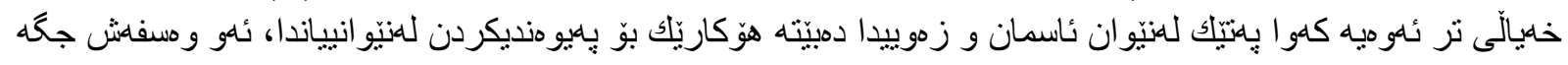

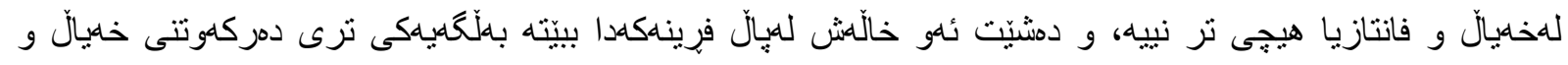

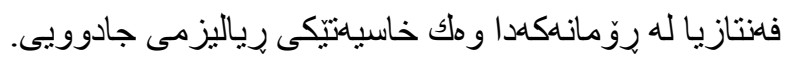




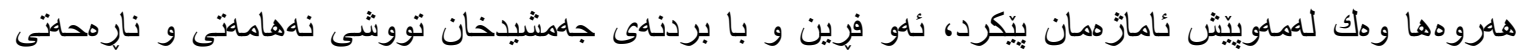

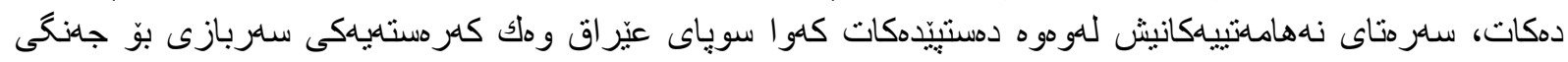

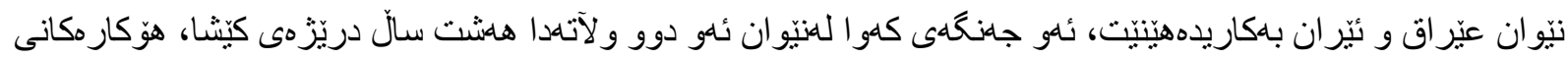

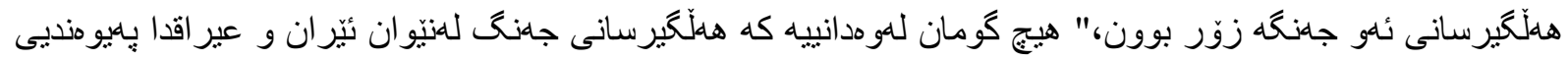

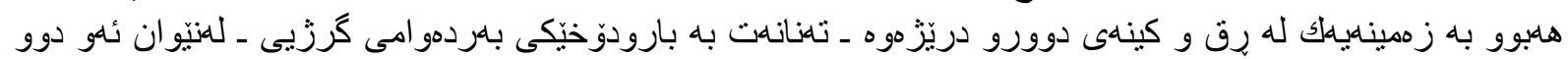

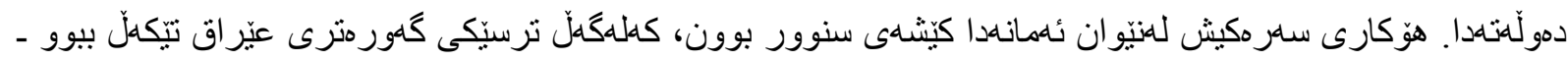

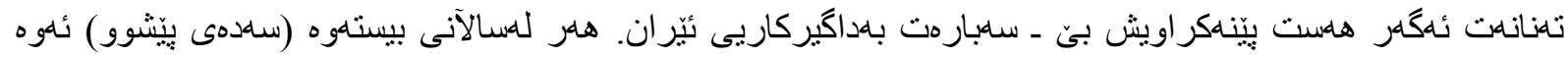

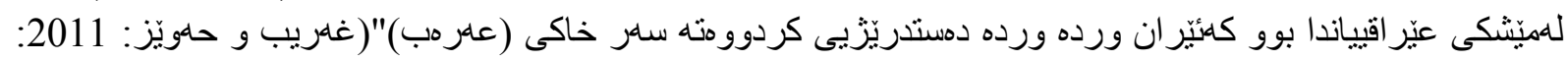

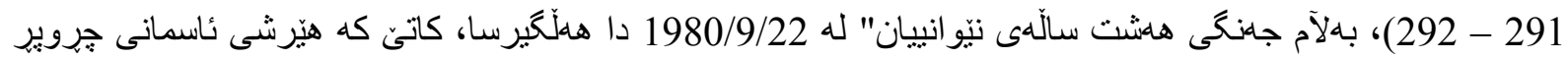

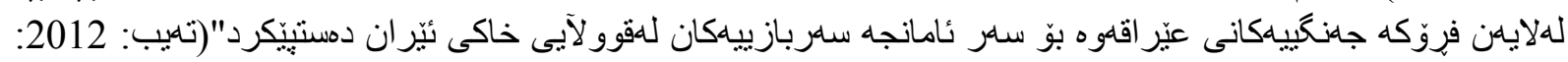

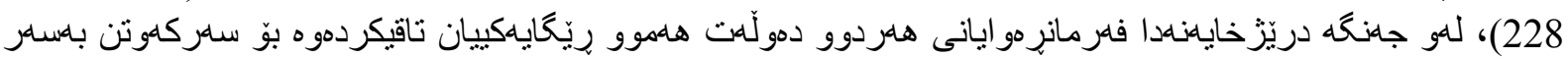

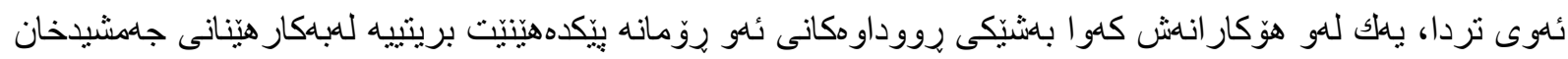

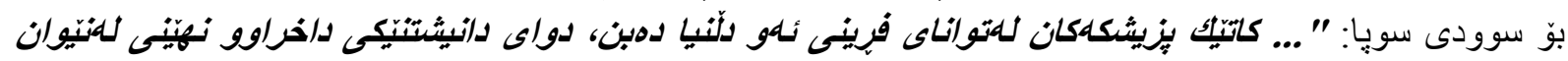

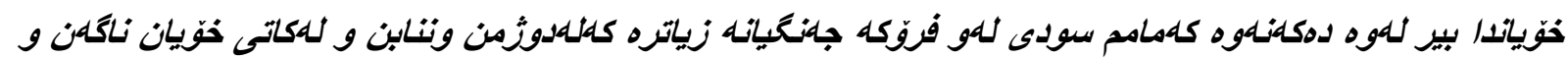

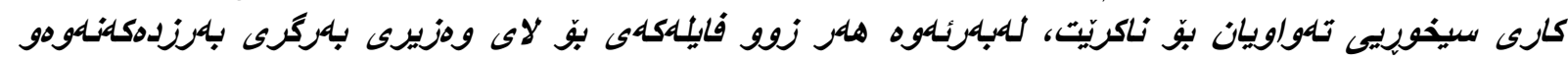

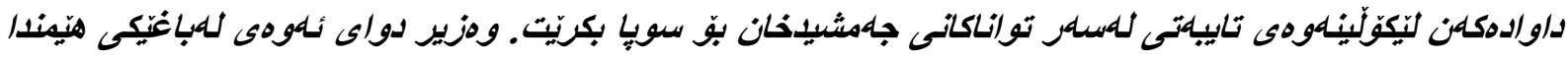

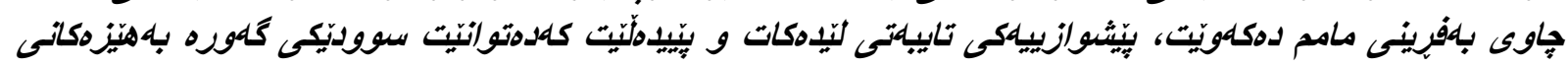

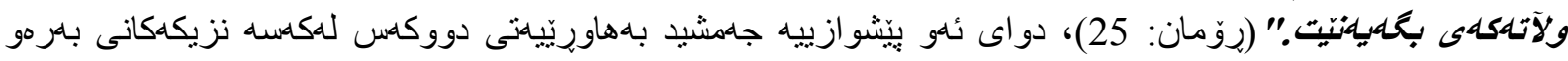

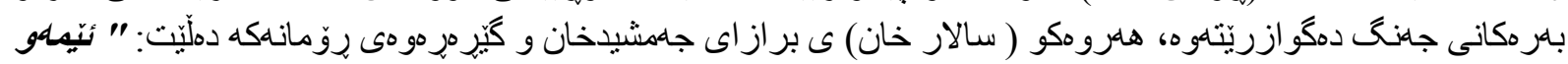

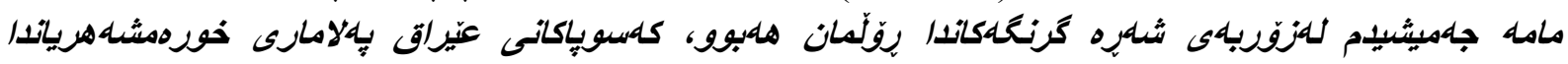

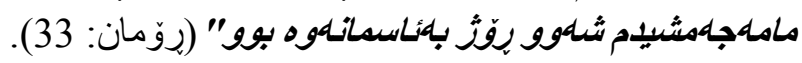

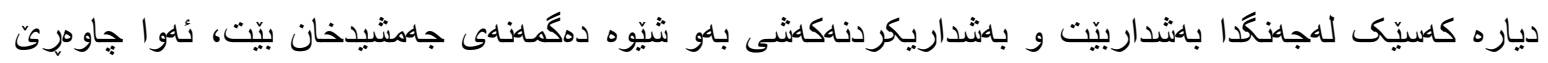

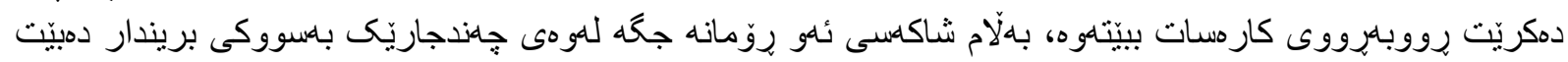

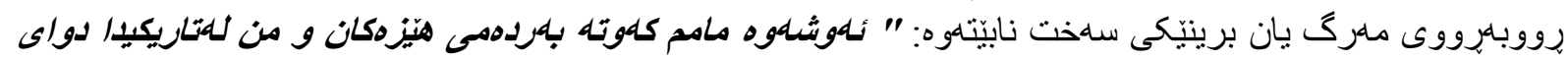

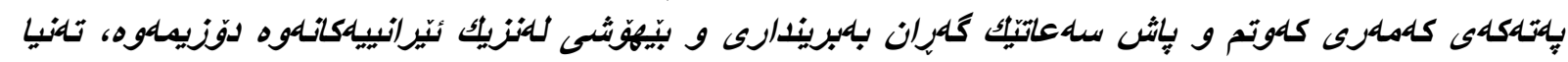

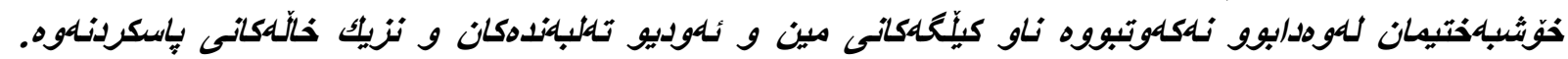

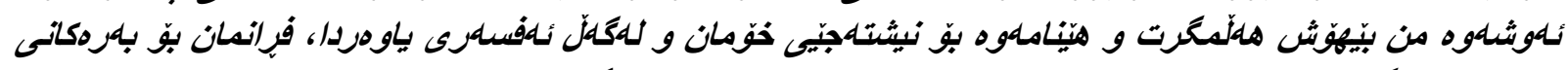

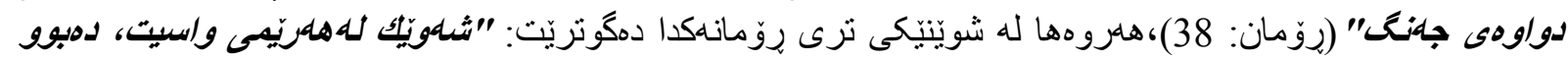

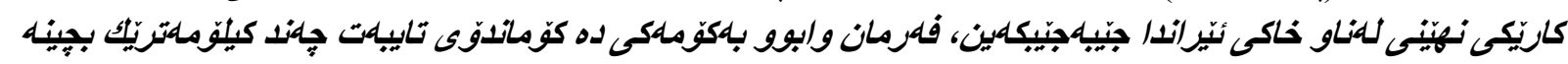

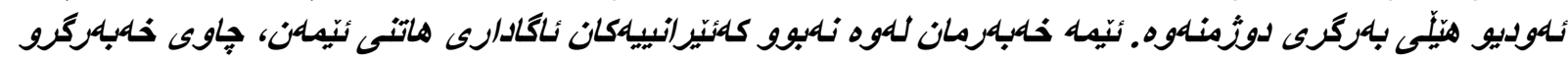

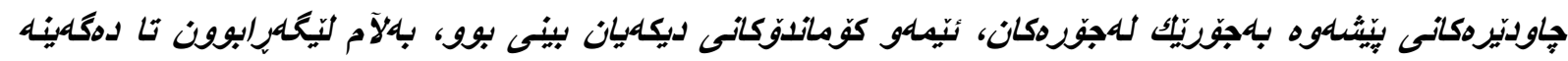

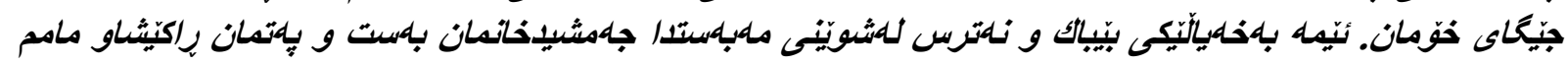

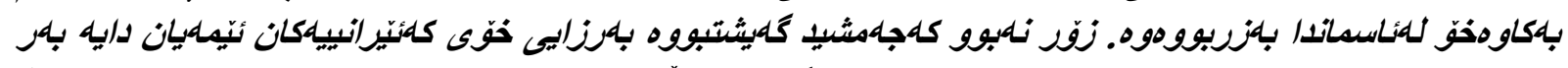

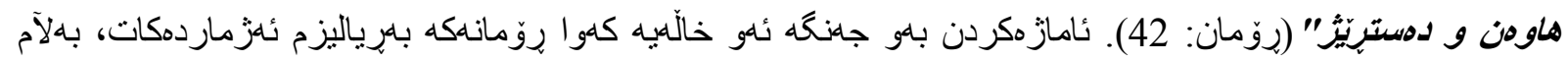

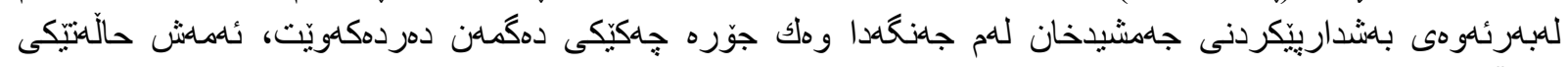

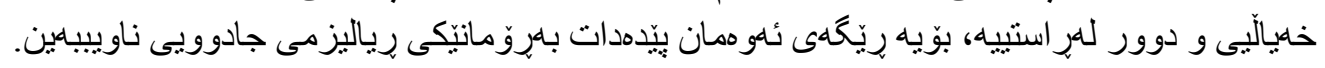

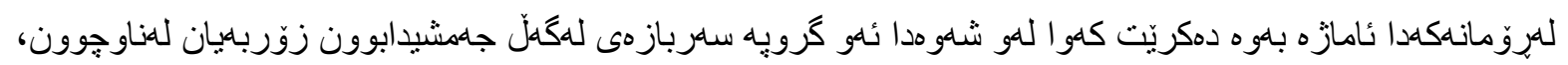

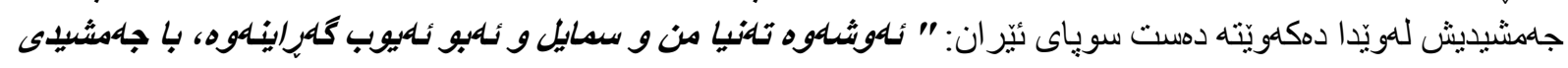

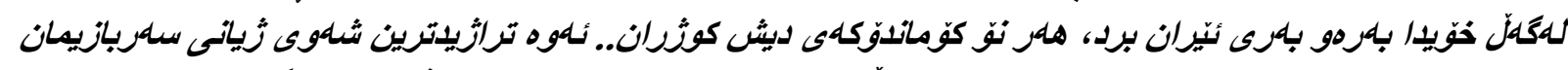

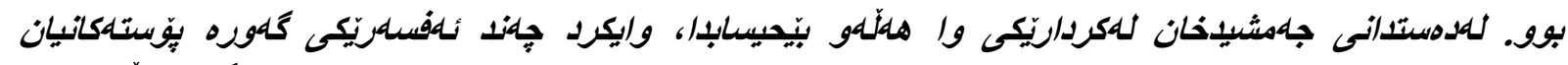

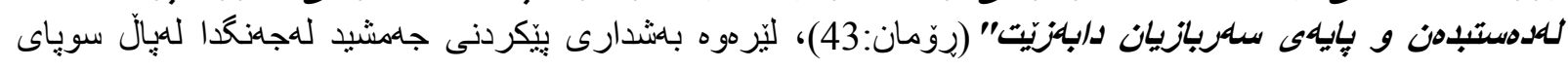




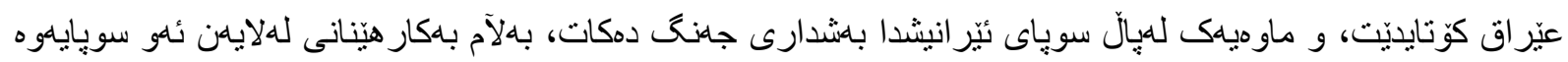

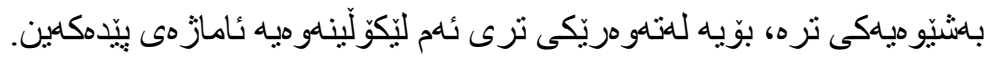

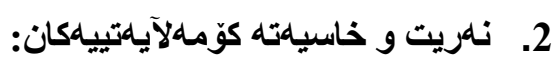

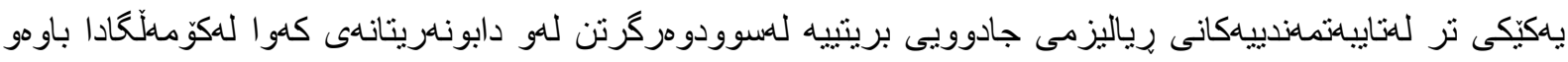

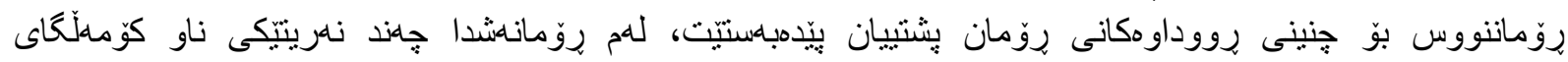

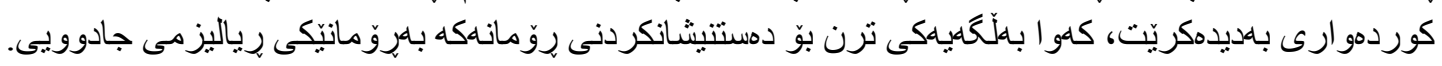

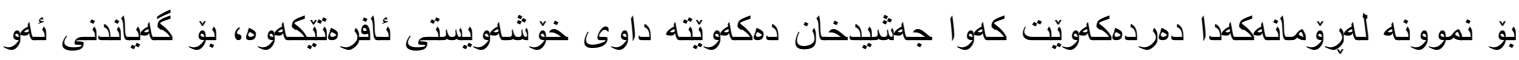

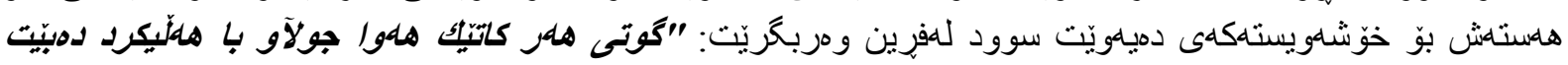

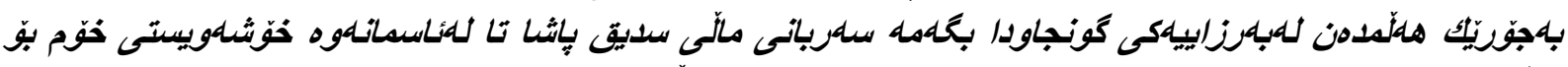

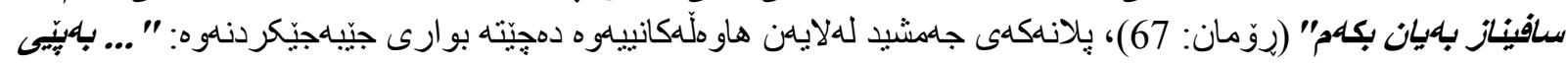

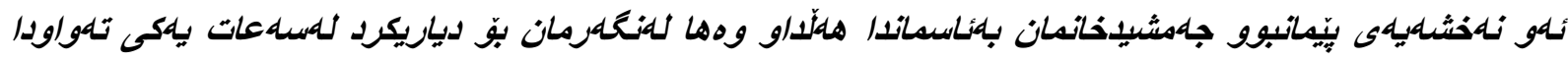

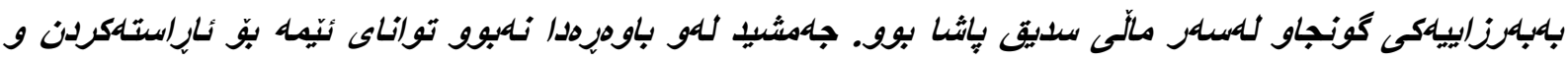

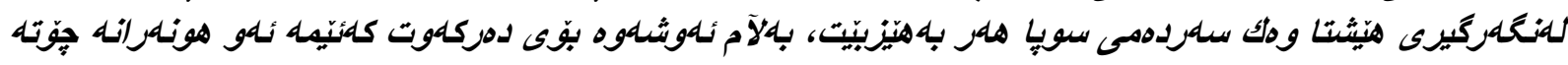

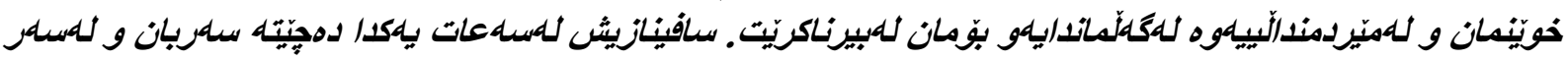

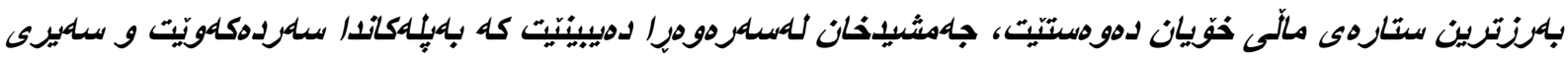

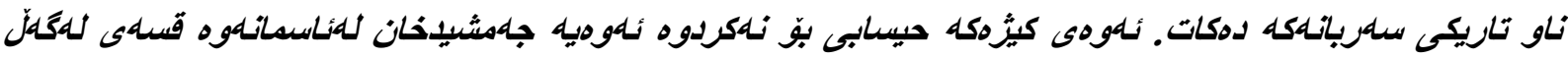

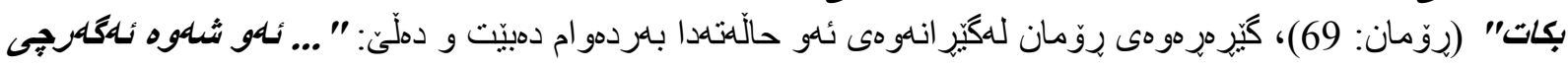

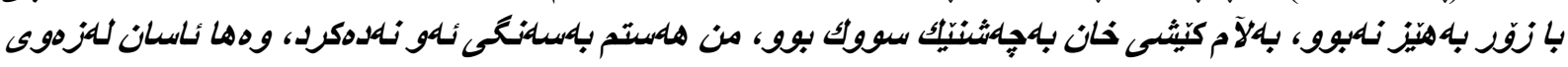

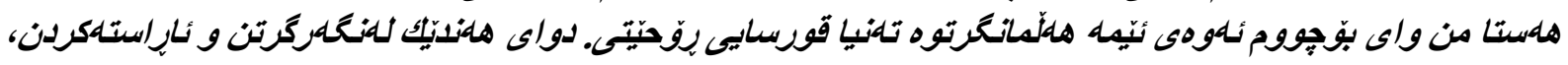

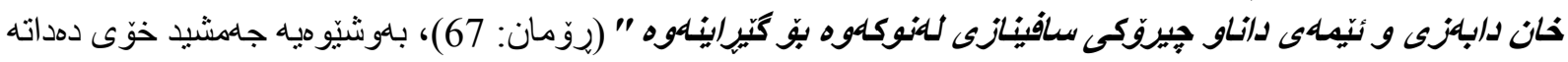

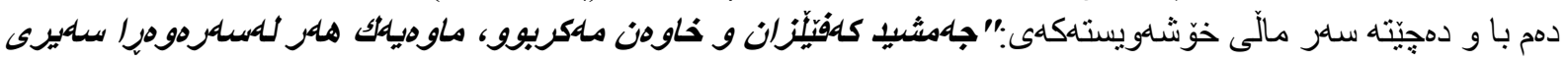

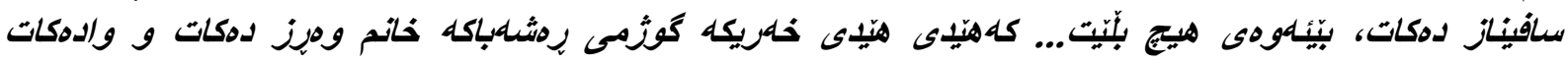

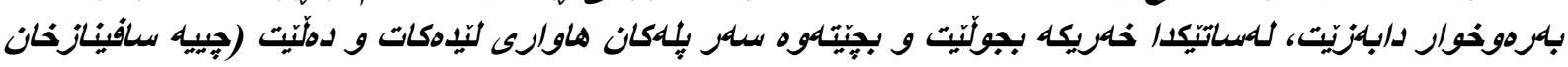

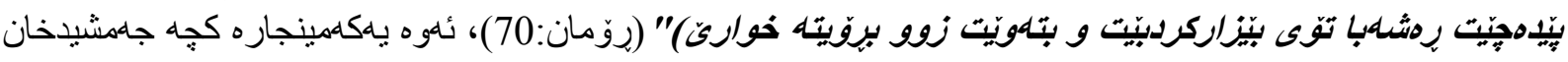

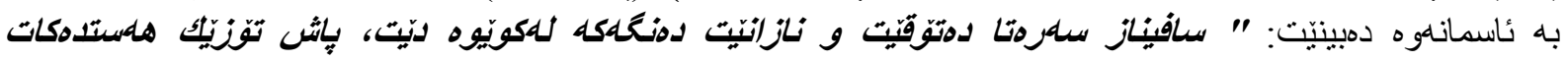

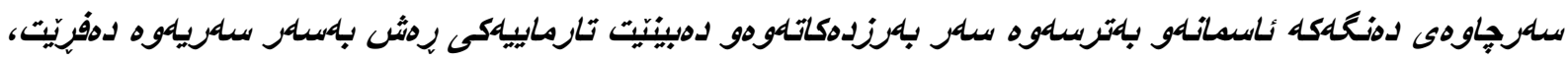

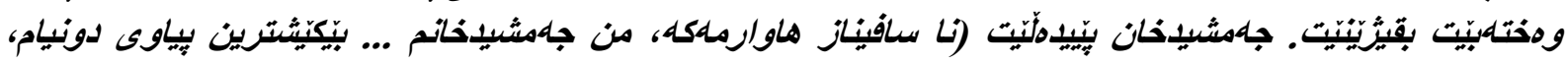

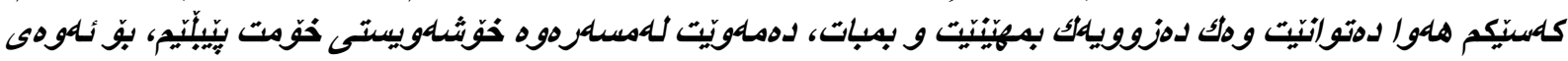

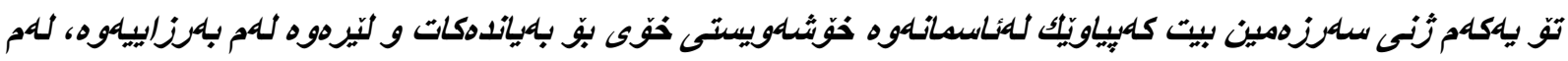

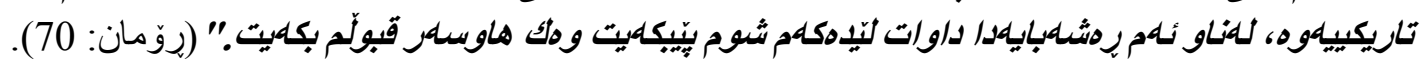

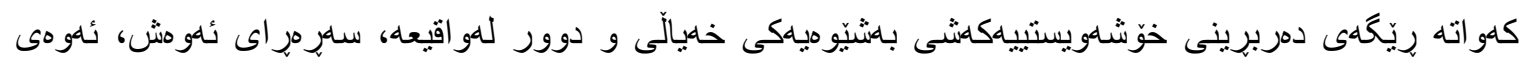

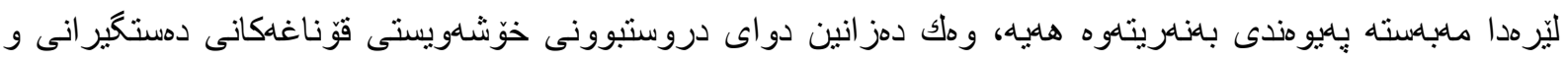

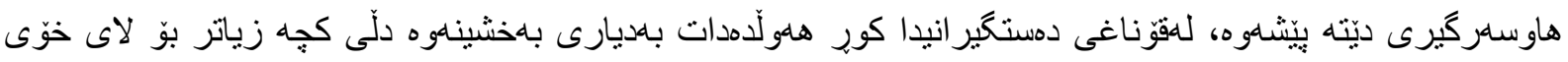

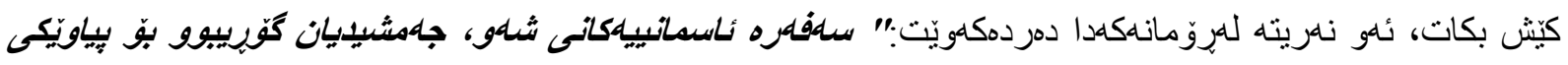

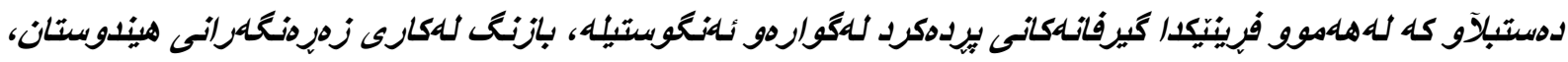

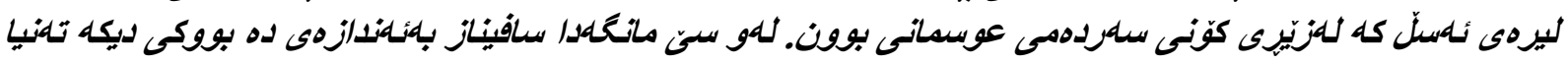

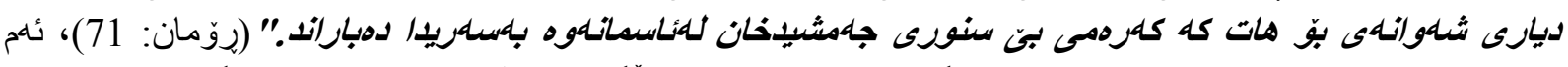

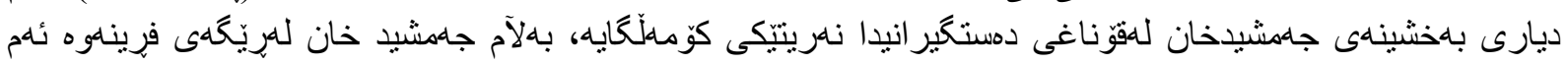

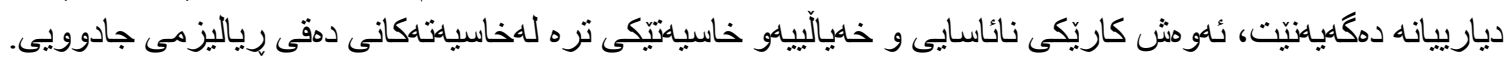

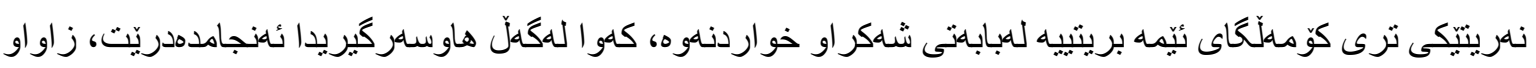

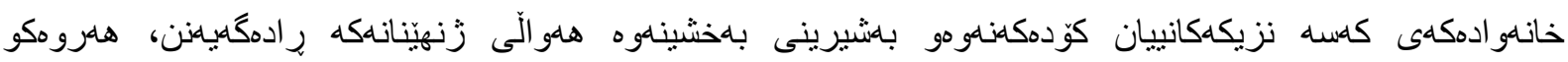




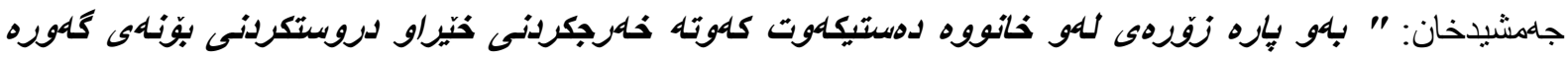

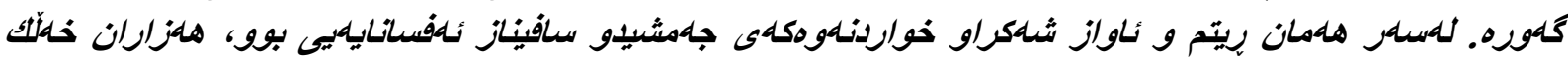

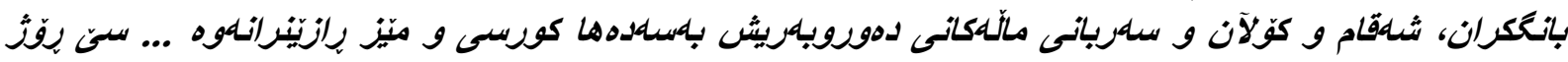

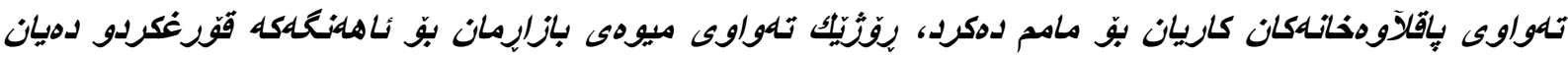

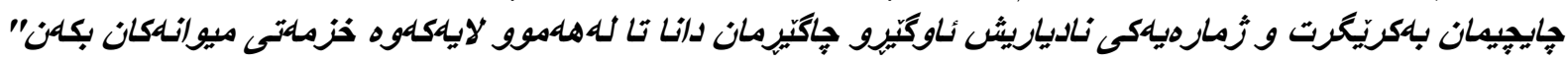

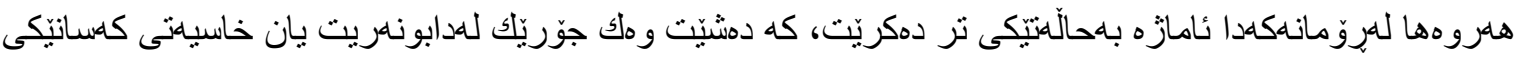

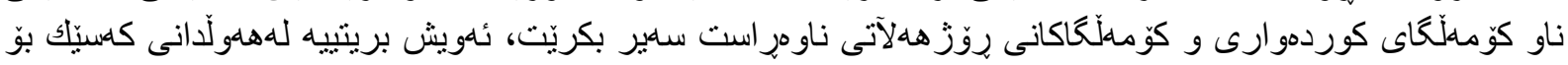

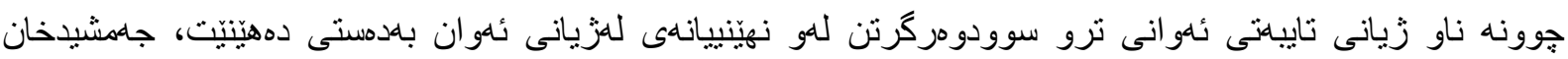

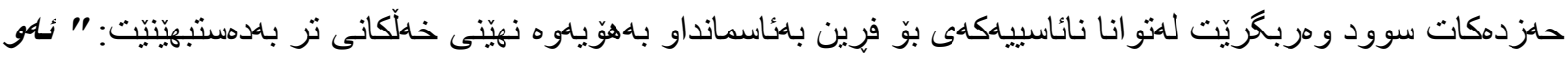

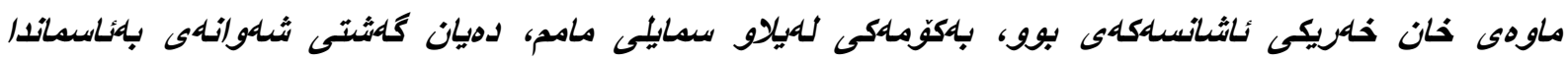

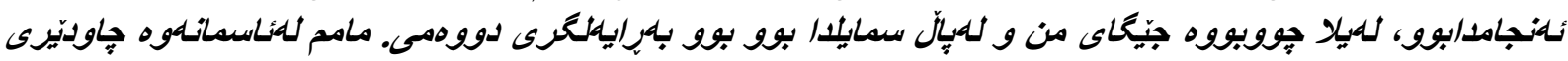

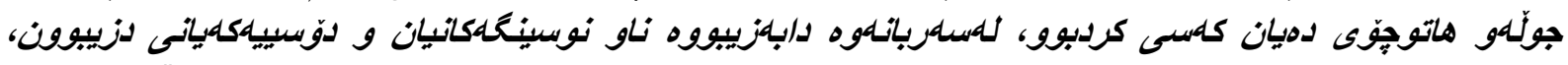

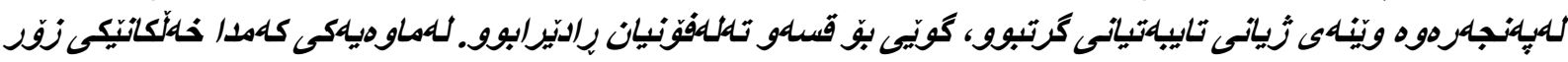

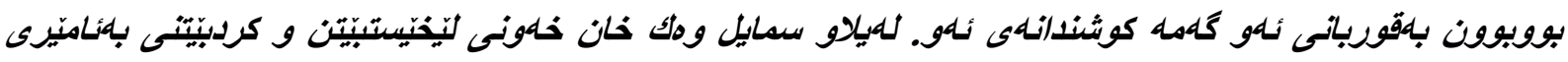

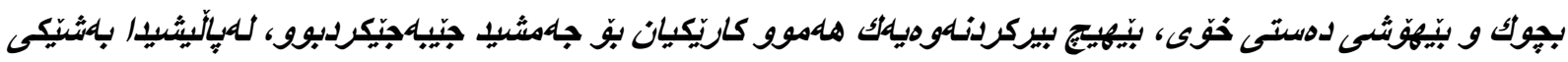

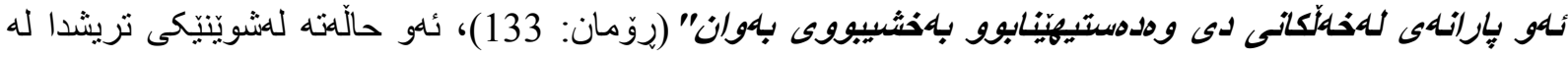

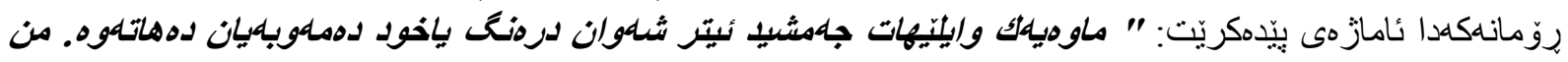

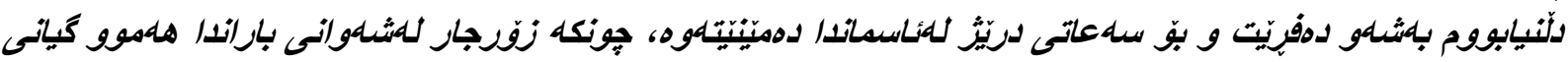

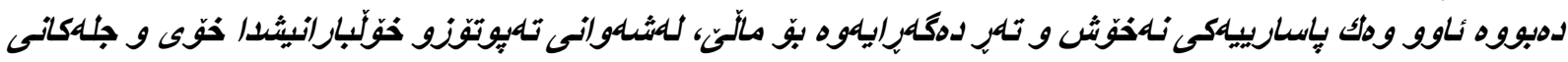

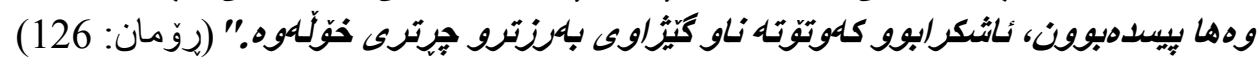

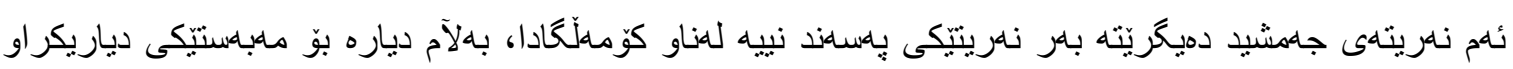

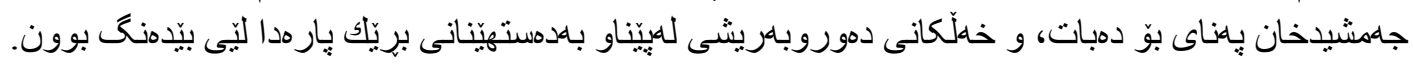

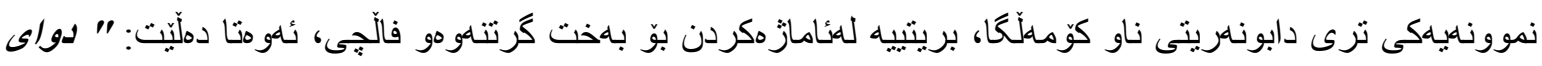

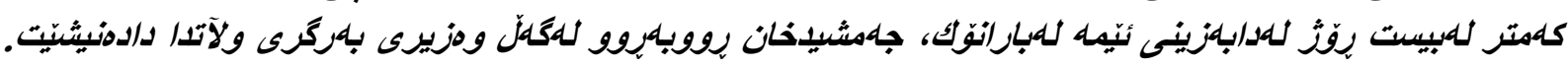

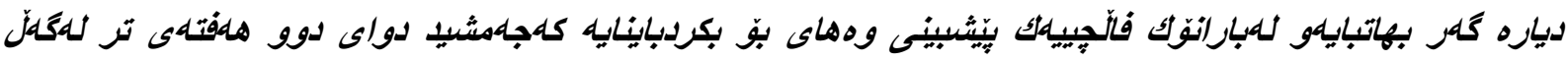

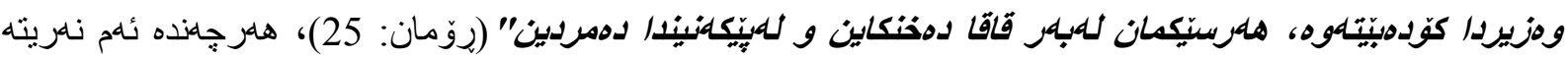

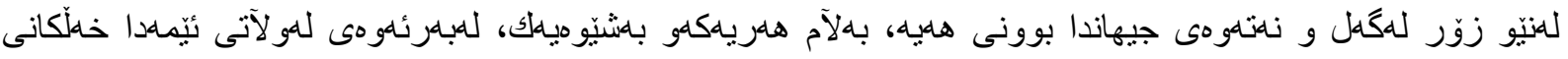

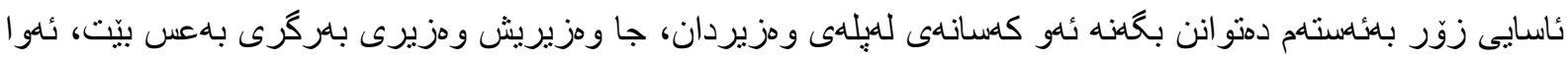

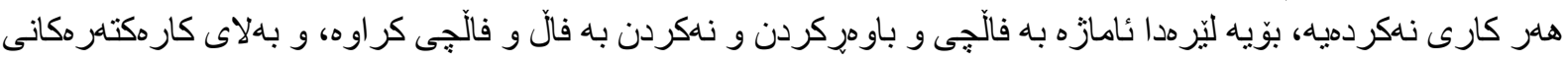

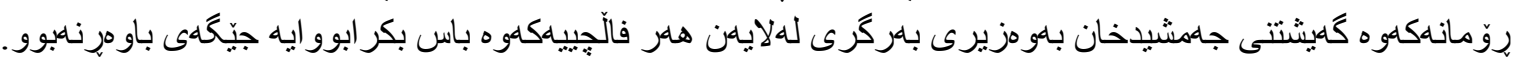

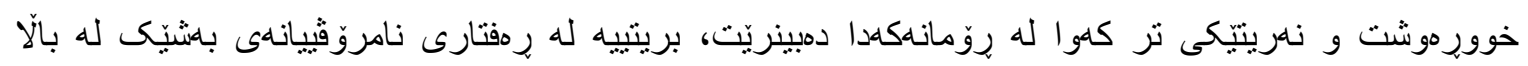

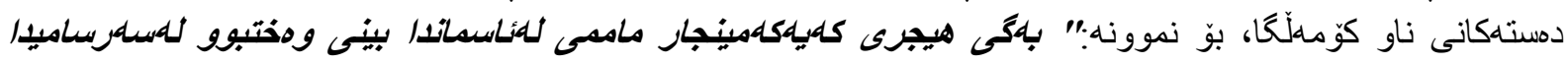

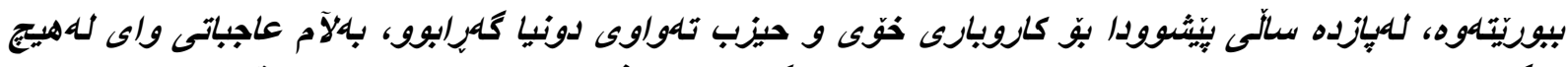

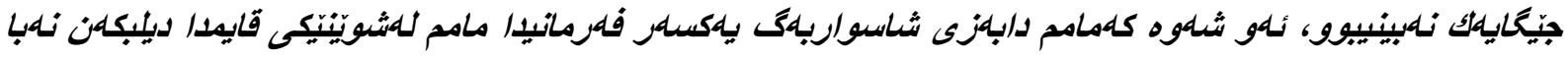

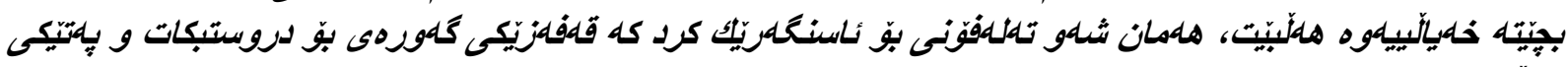

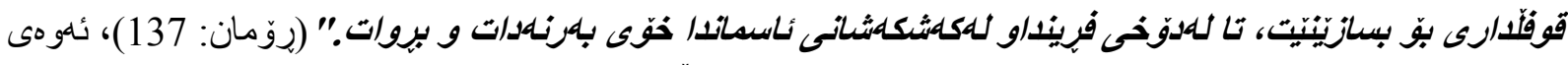

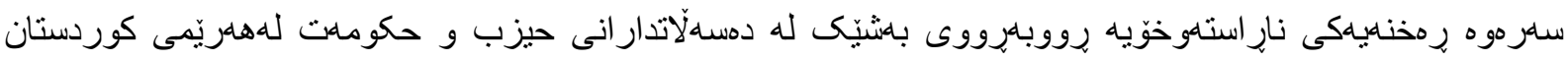

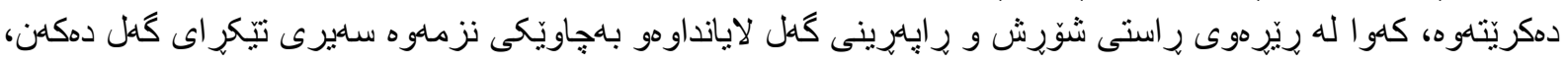

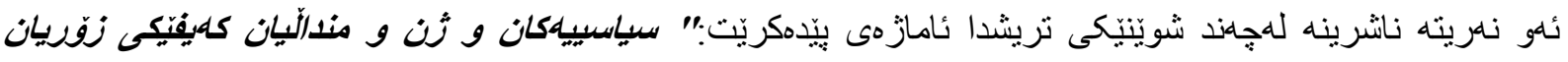

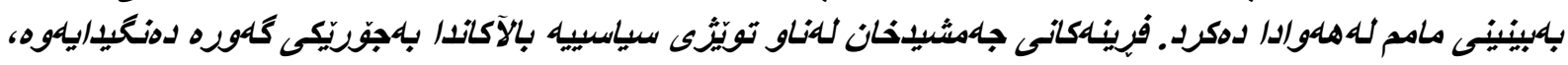




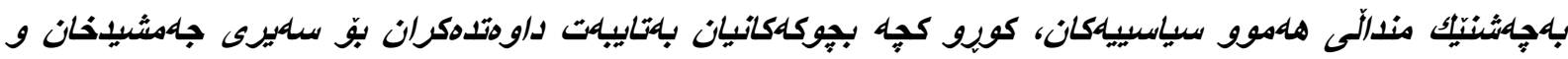

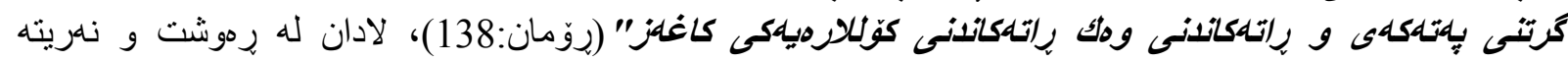

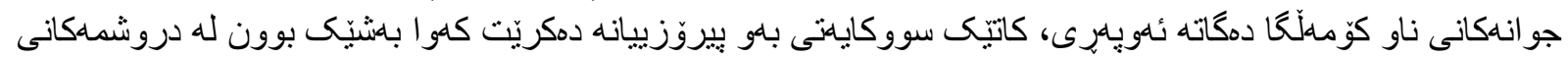

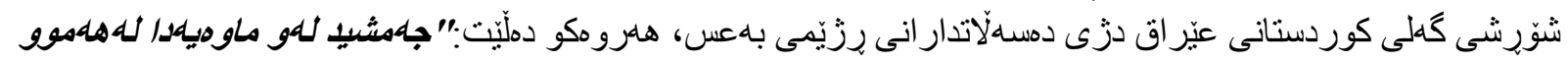

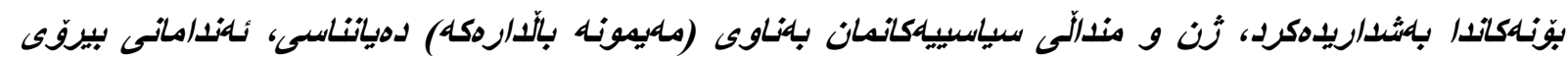

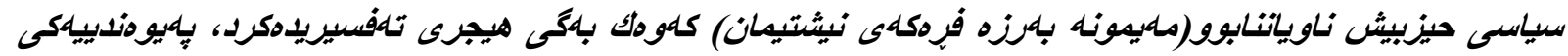

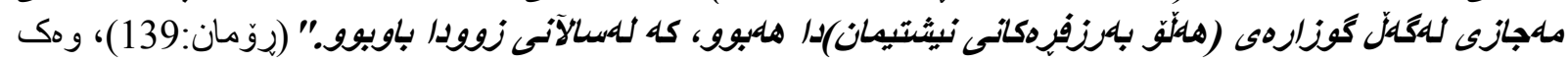

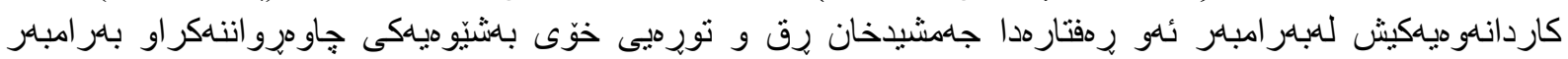

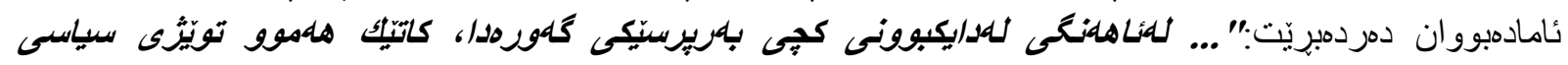

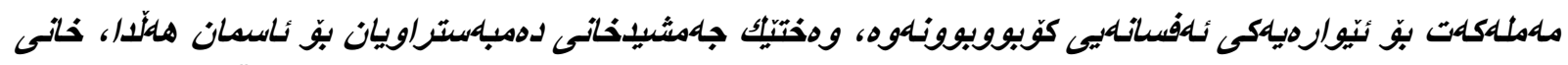

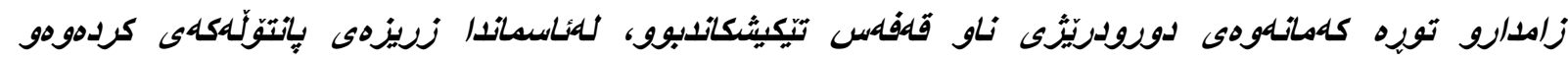

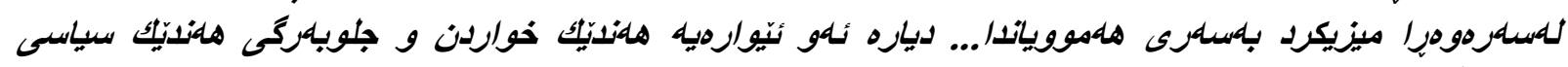

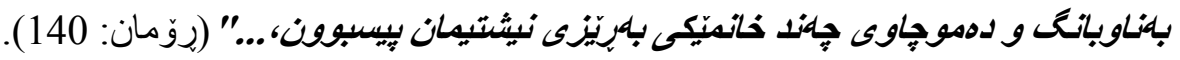

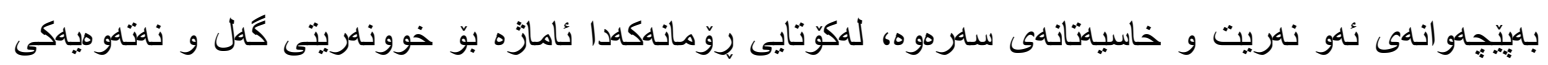

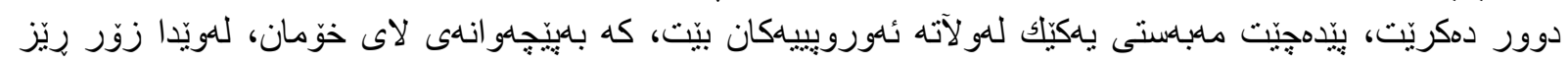

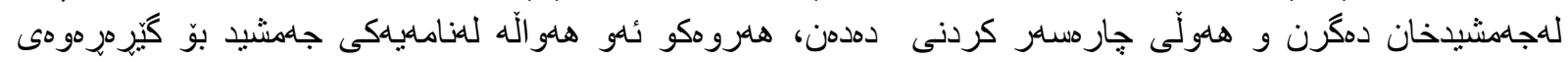

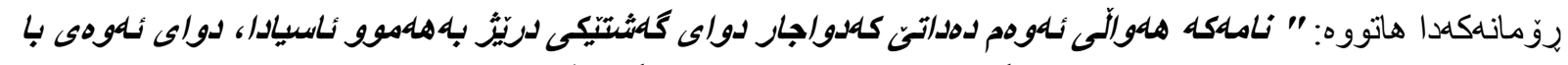

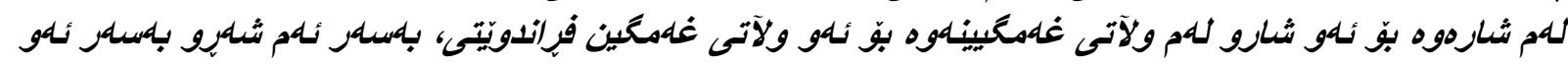

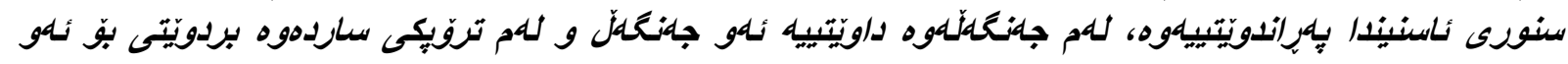

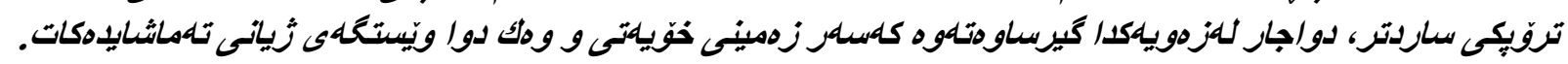

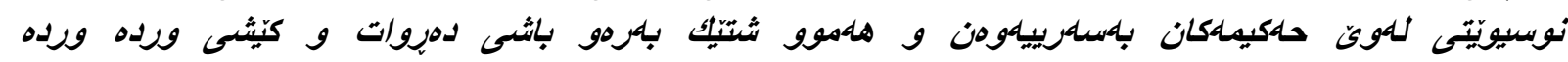

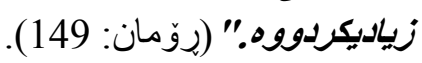

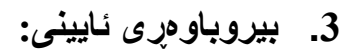

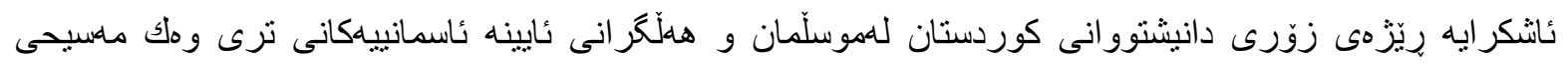

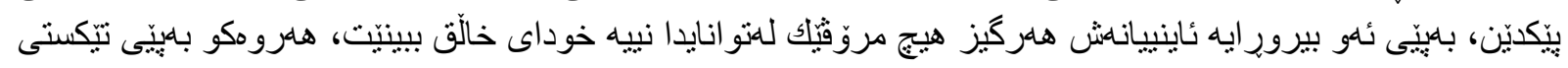

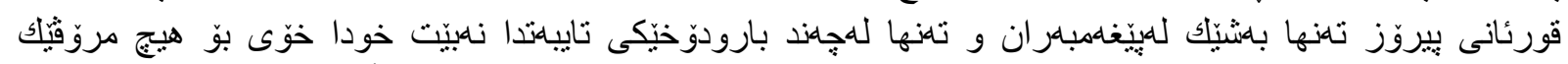

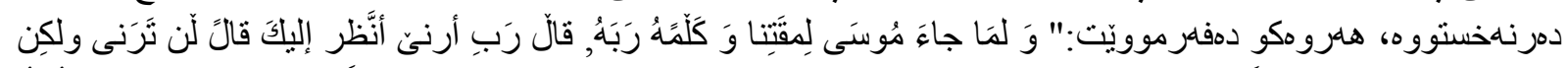

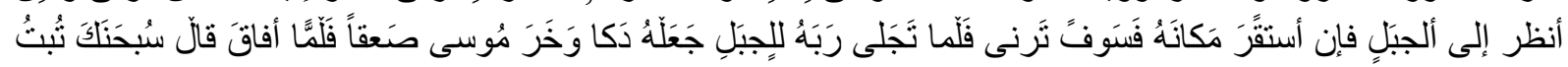

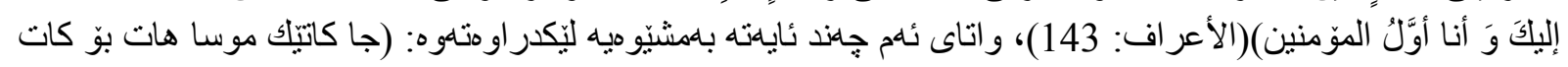

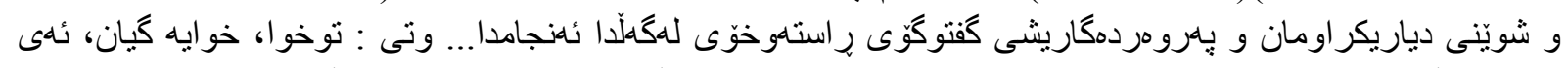

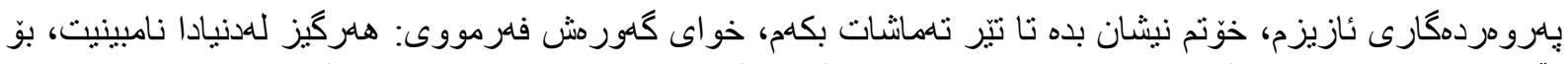

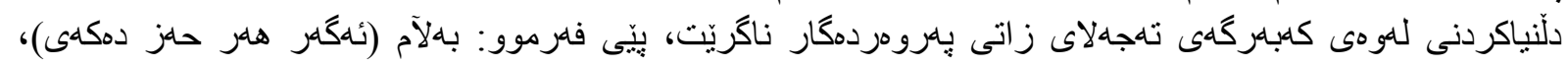

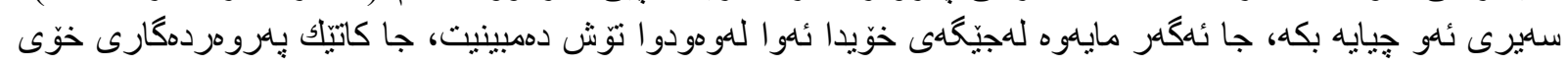

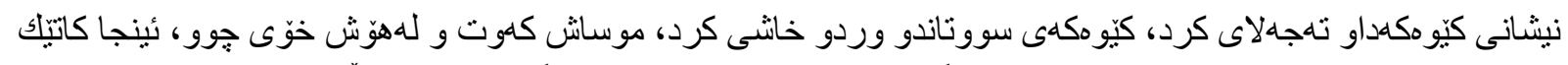

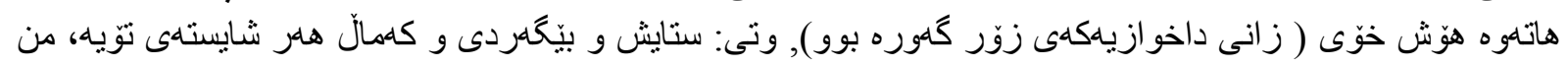

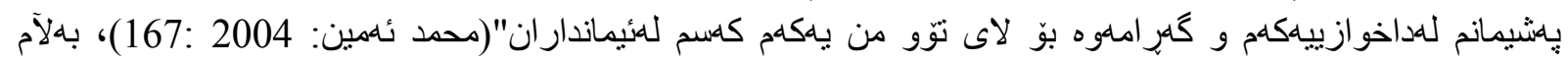

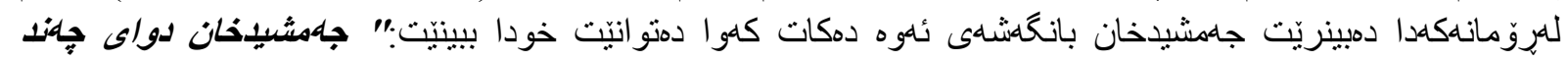

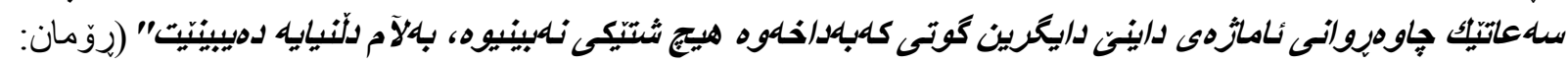

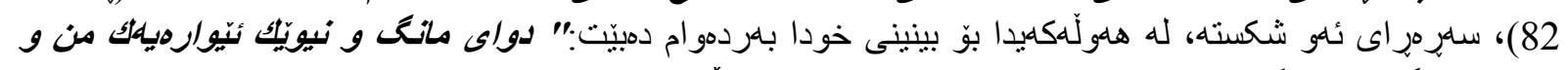

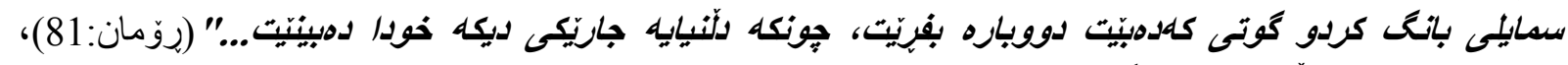

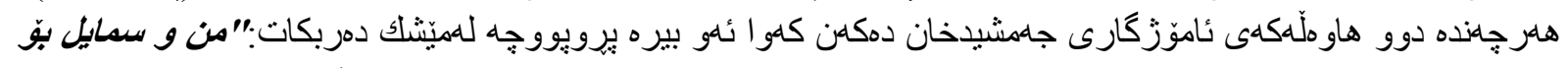

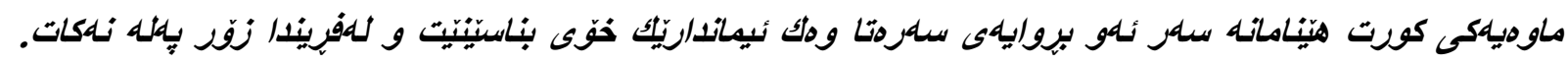




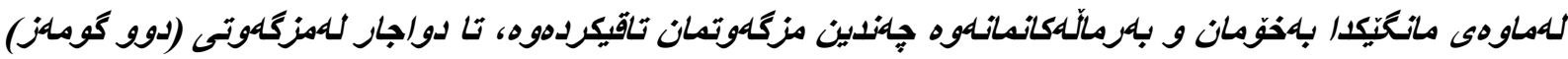

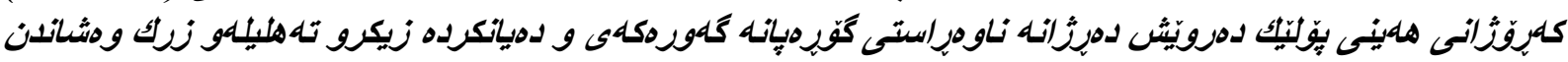

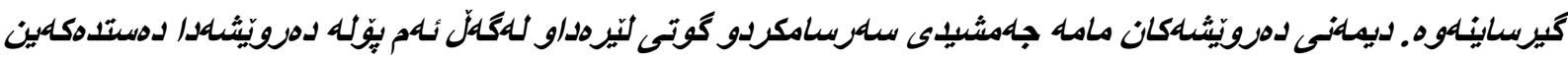

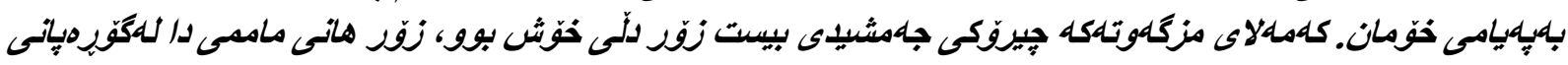

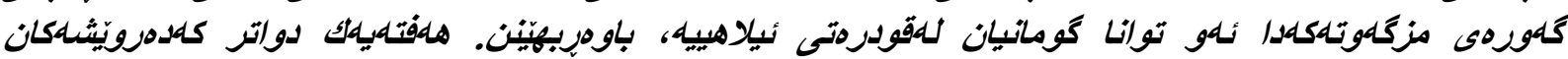

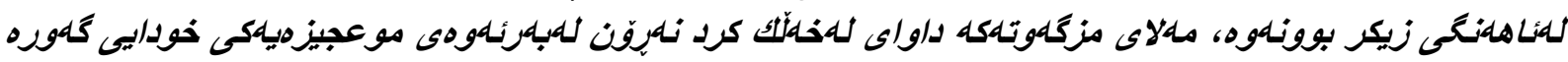

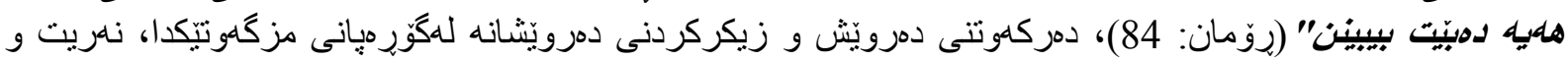

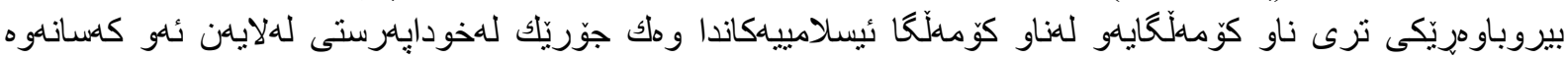

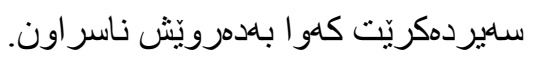

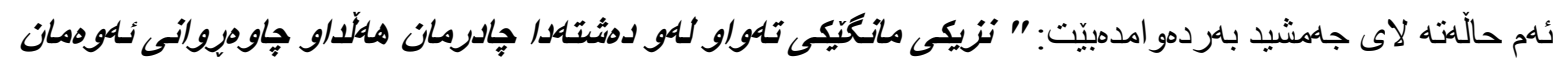

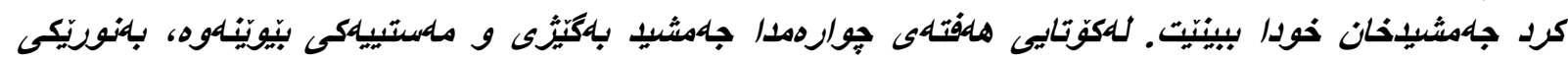

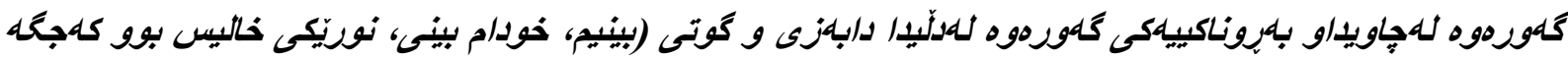

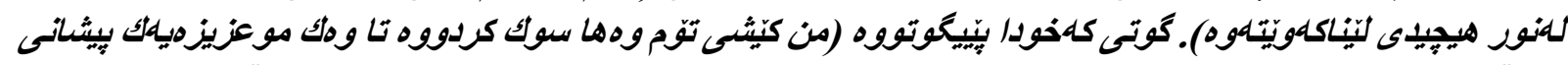

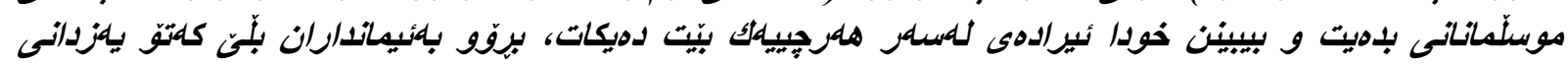

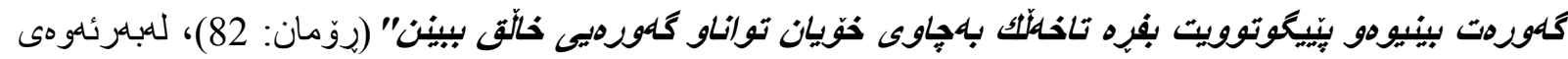

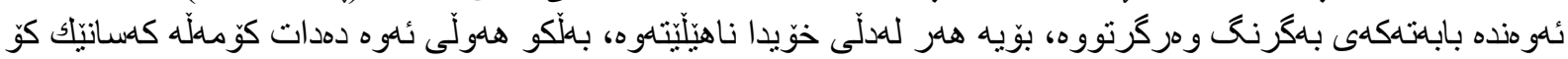

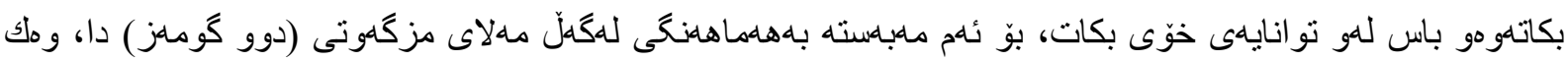

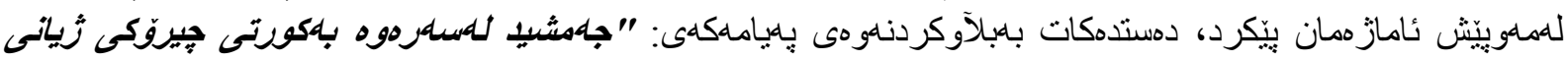

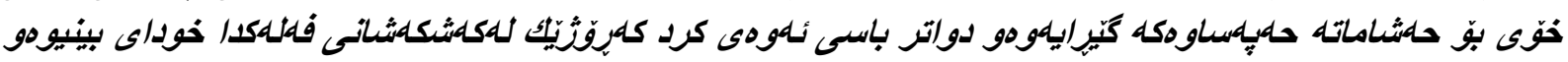

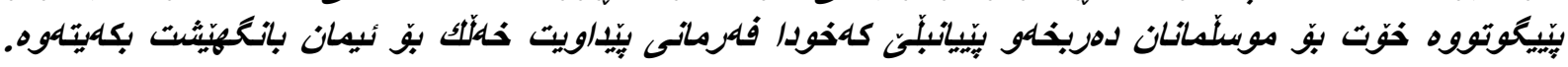

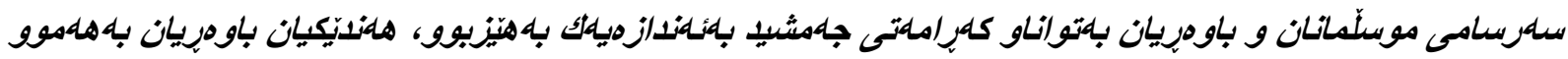

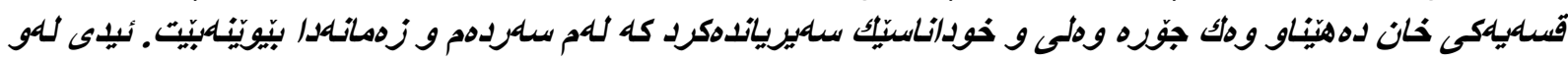

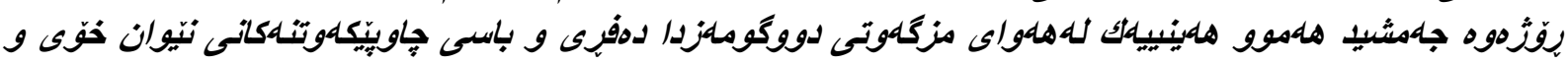

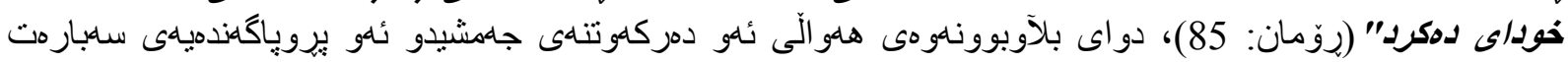

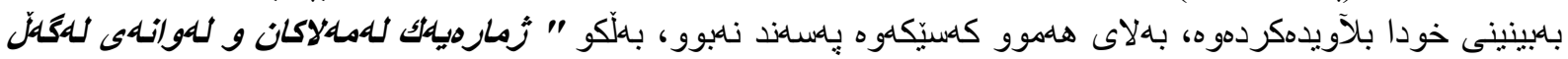

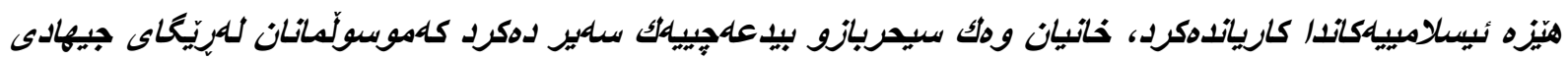

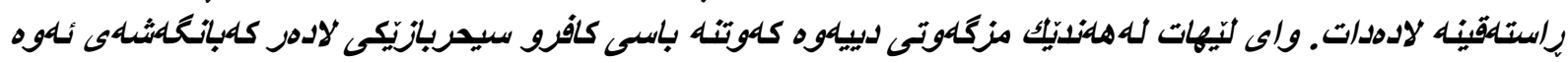

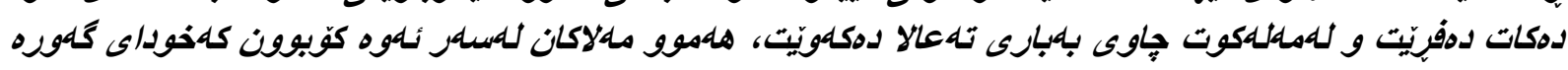

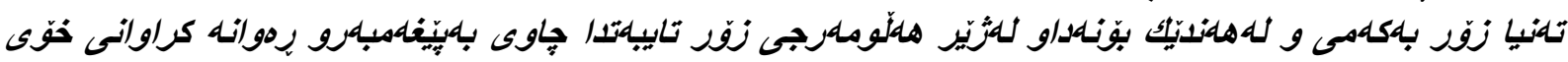

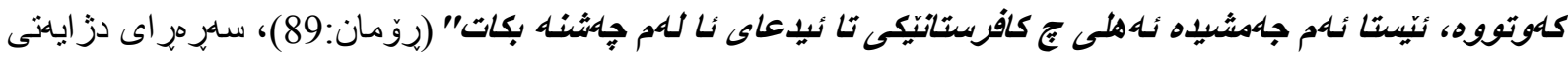

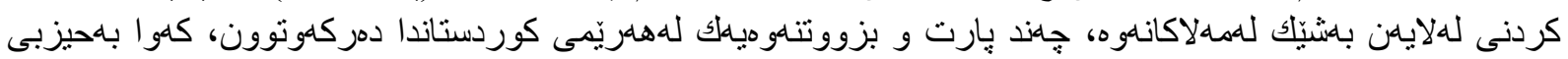

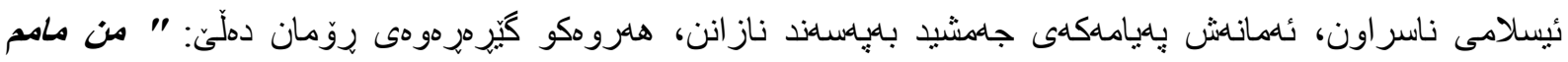

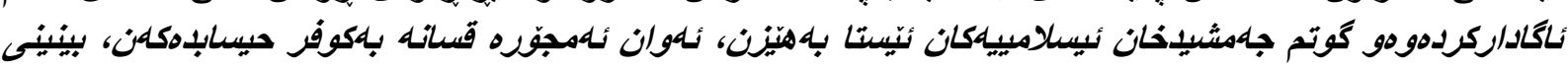

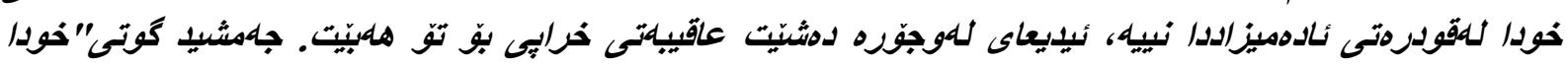

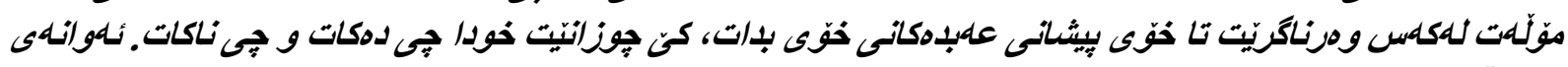

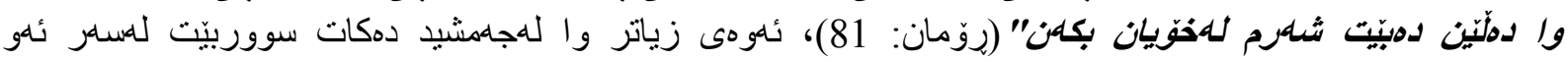

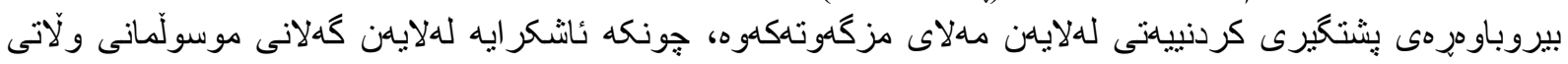

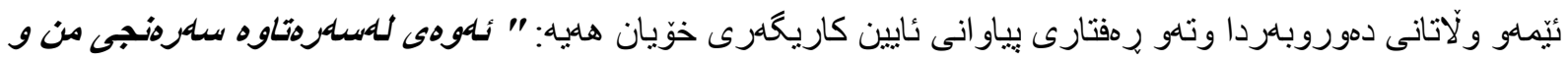

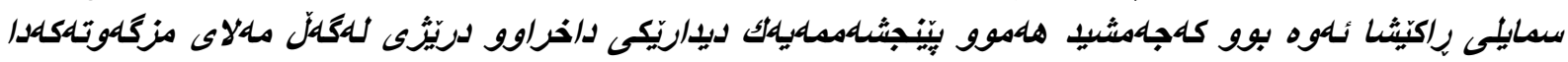

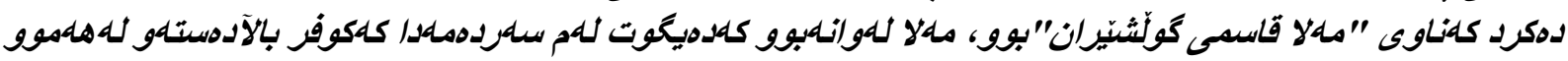

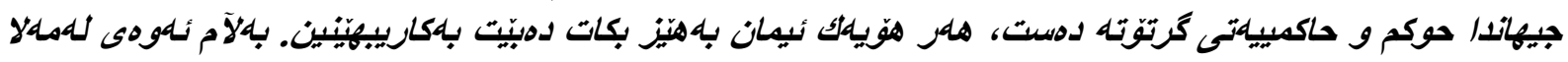

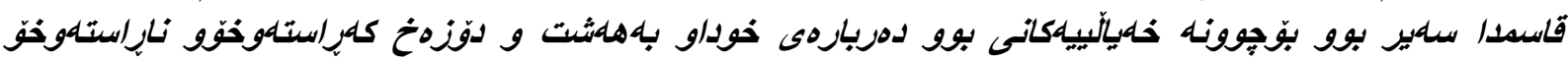

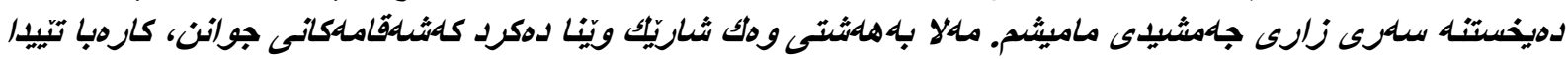




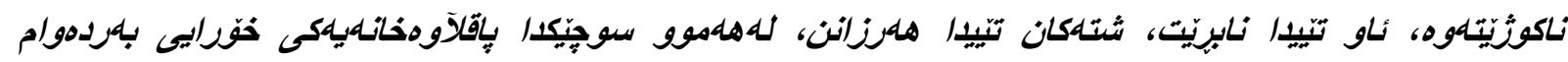

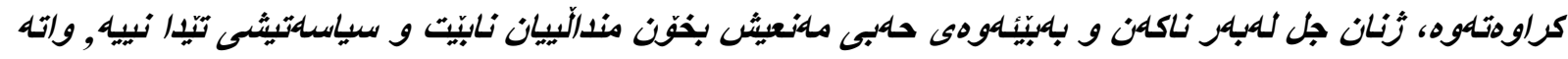

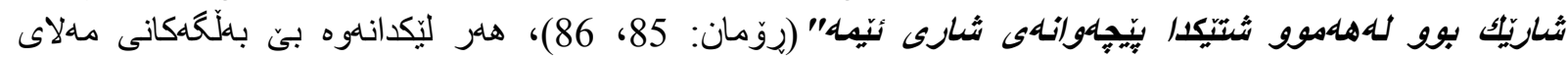

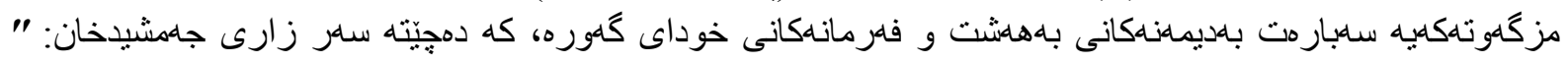

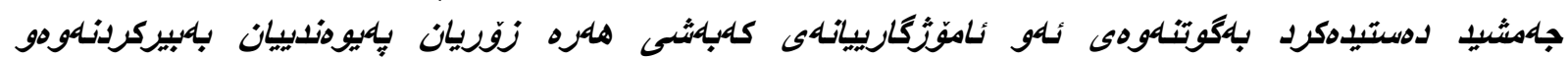

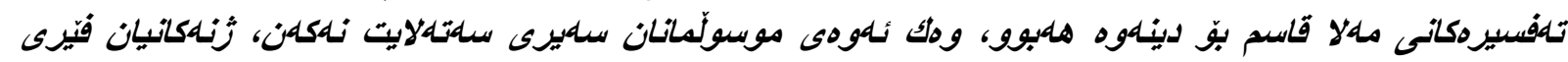

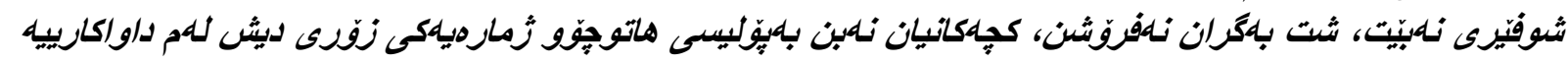

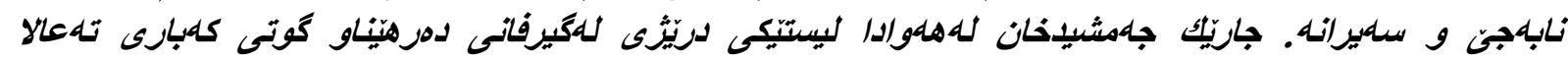

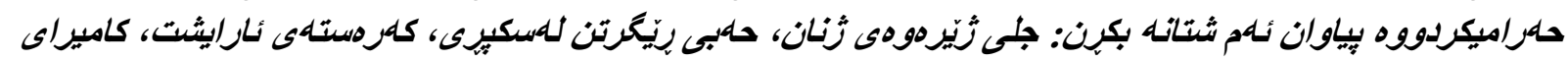

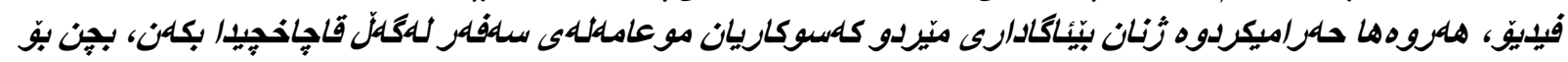

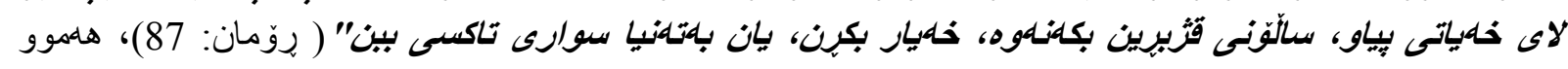

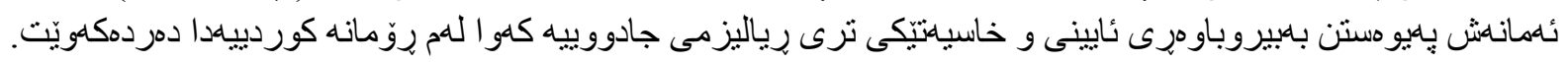

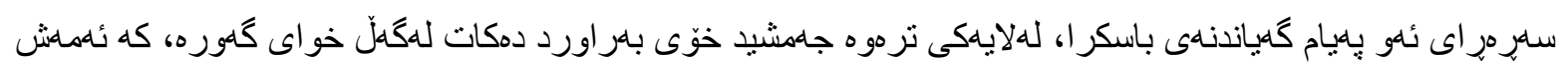

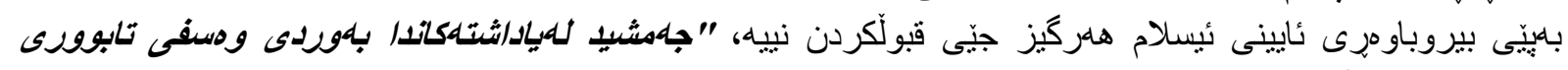

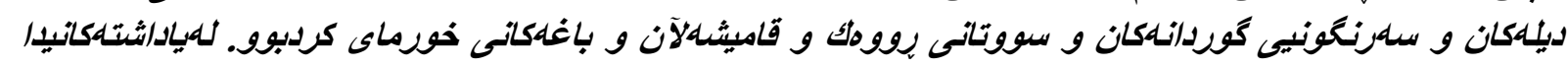

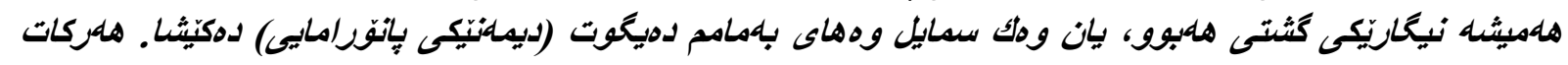

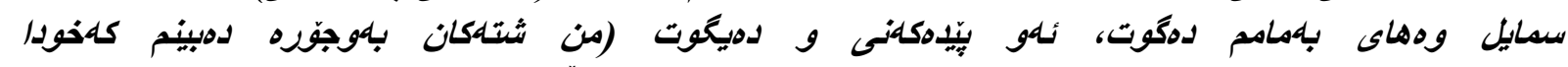

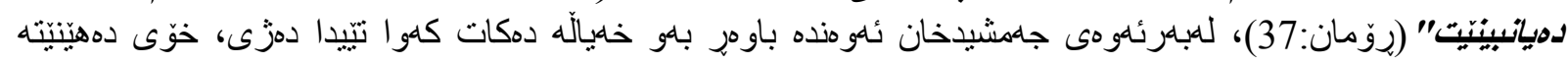

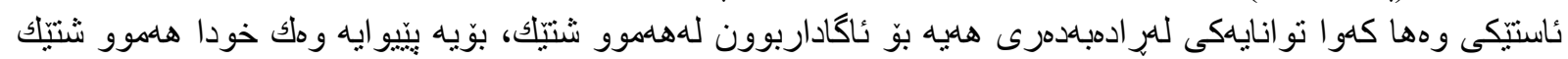

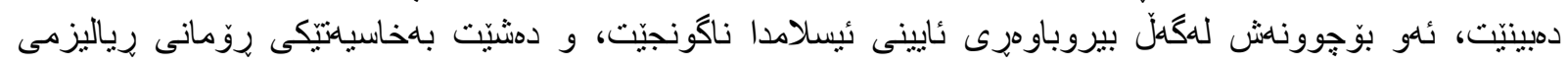
جادوويى دابنريّت.

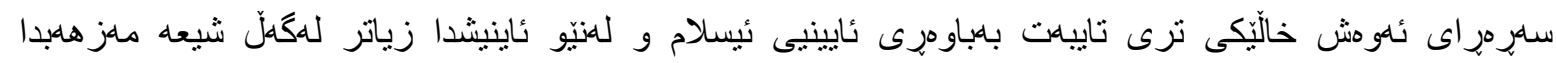

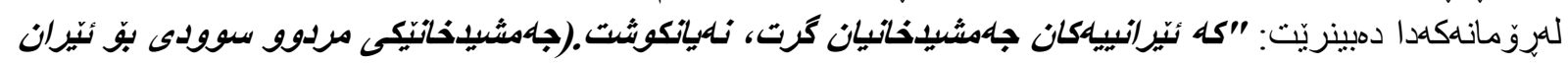

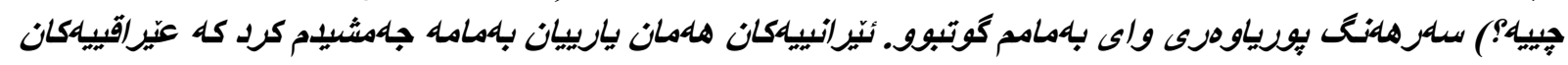

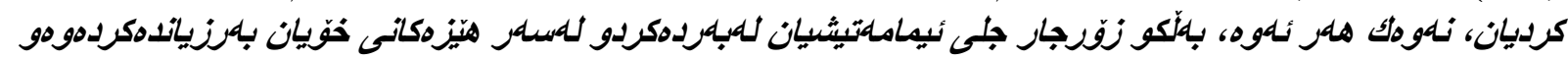

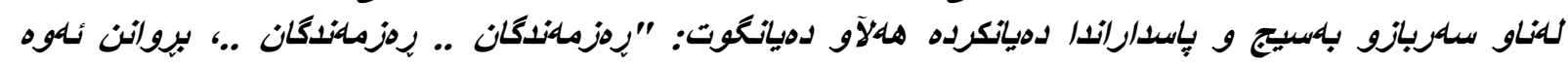

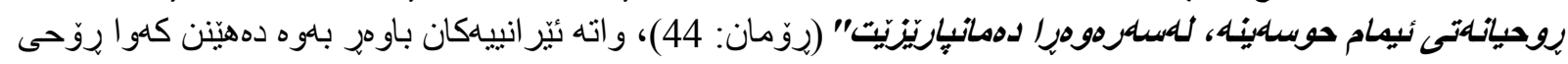

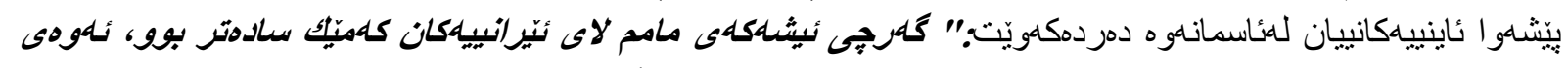

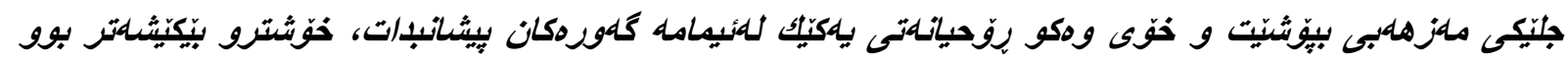

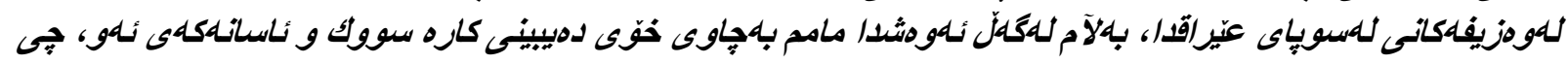

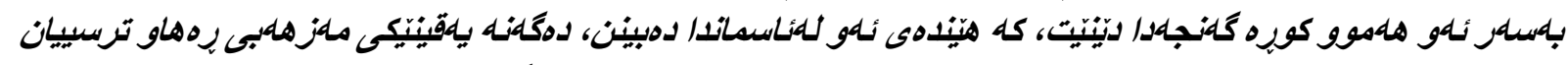

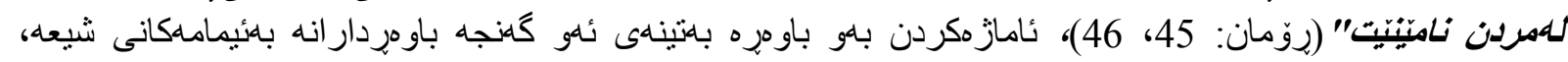

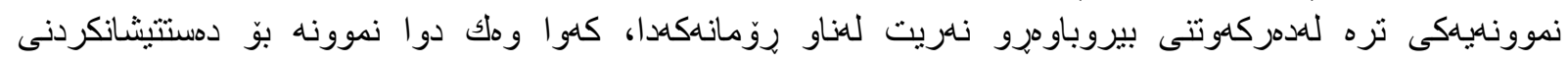

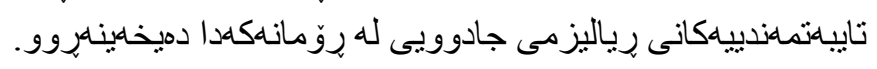

ئنانجام

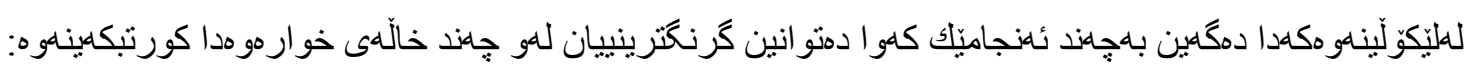

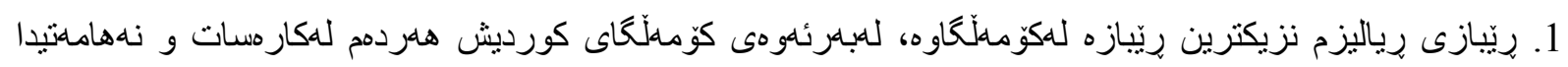

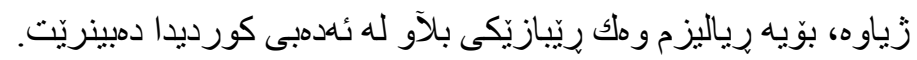




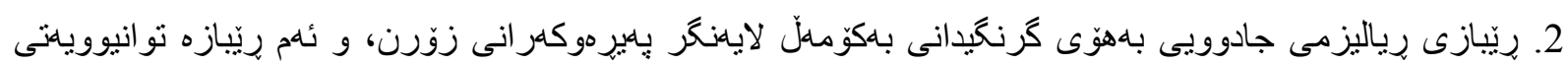

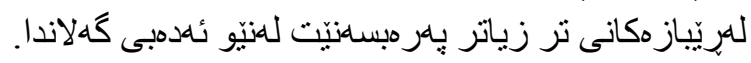

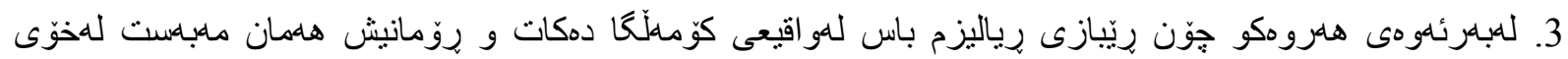

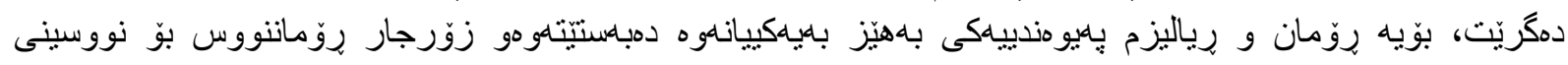

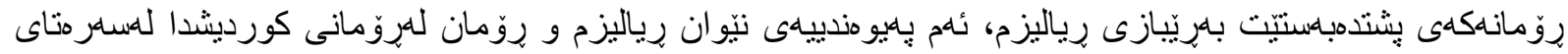

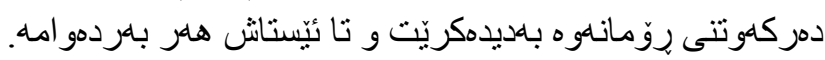

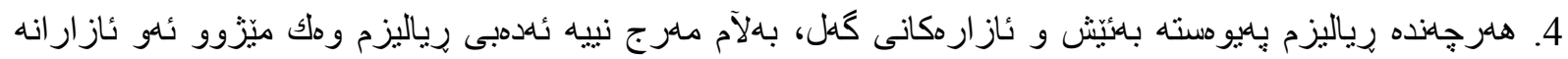

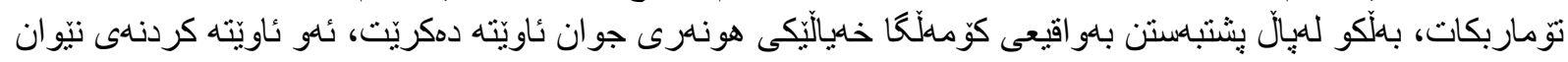

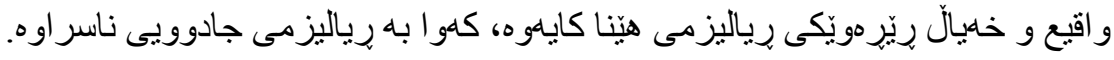

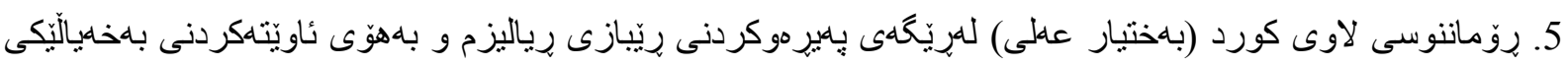

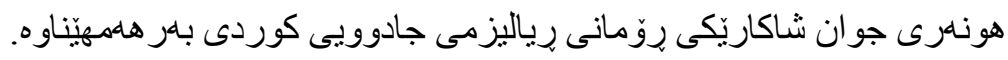

سلرجاوهكان

\section{1

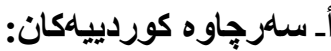

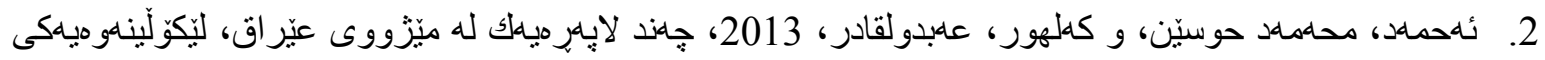

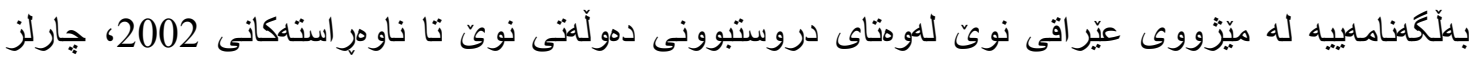

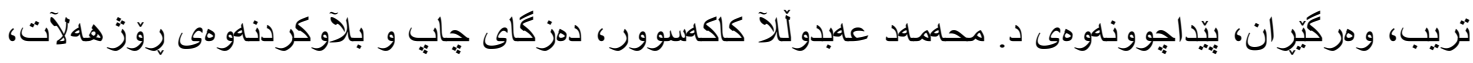

جايَى سيّيام.

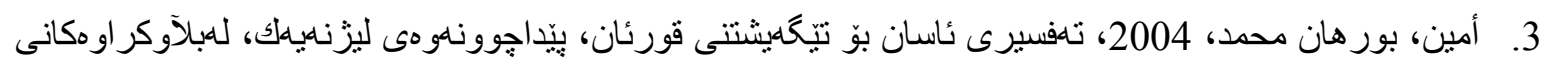

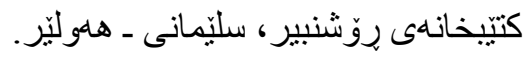

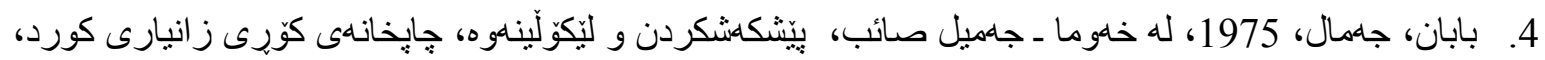

باغذا.

5. ت تهيب، (د.) جهمال فهتحولّلّا، 2012، بزووتنهوهى رزكاريخو ازى كورد له بانشوورى كوردستان (1975/3/21

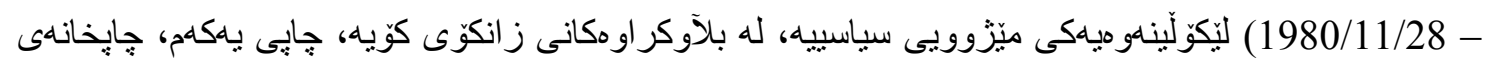

شاهواب، هلوليّر.

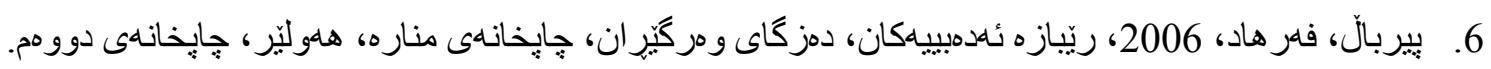

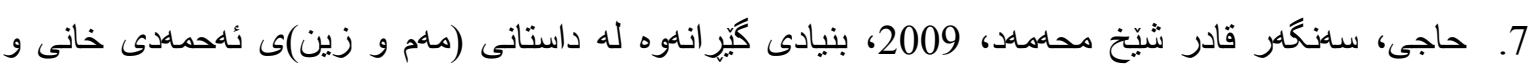

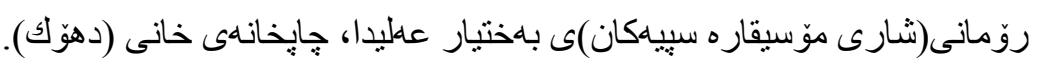

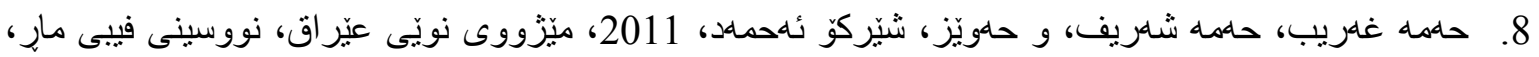

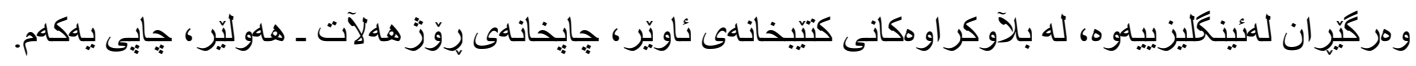

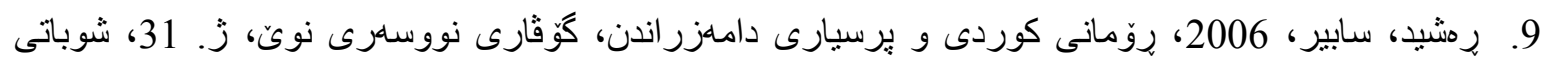




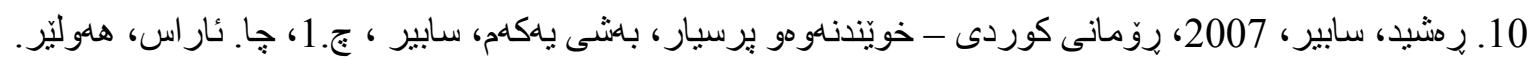

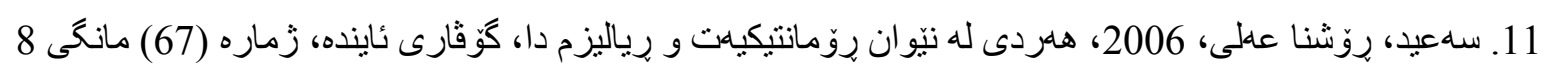
$.2006 /$

12. گَرميانى، عادل مهجيد محمهد، 1996، رياليزم له روّمانى كوردى هاوجهرخ له عبّر اقدا، نامهى ماستهر،

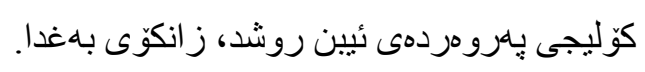

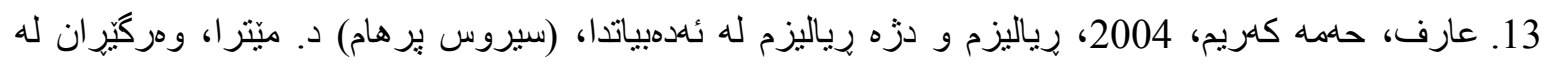

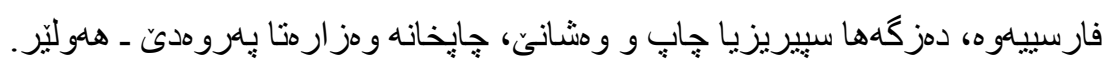

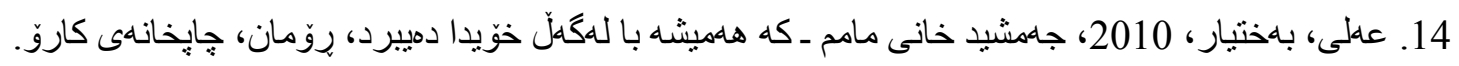

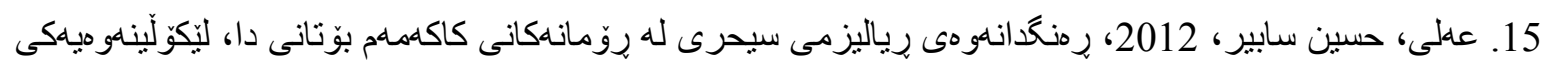

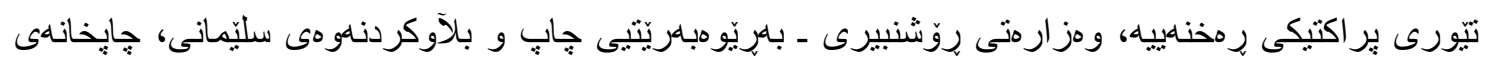

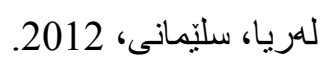

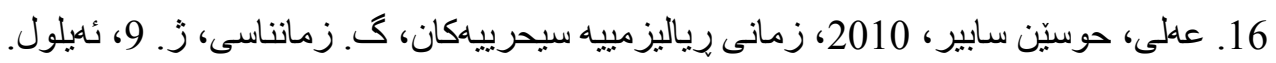

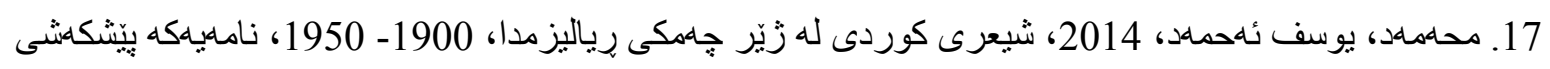
ئنسنجو مهنى سكولى زمانى ز انكوّى سليّمانى كردوره.

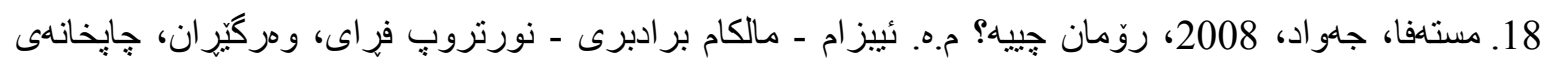
خانى (دهوَك)، جإيى ينكام.

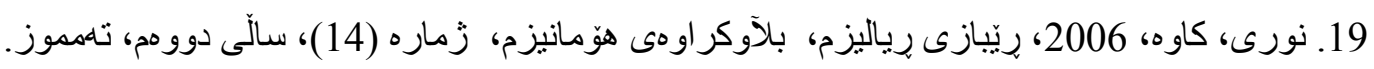

20. مصطفى، فائق، و على، عبدالرضا، 2000، فى النقد الأدبى الحديث ـ منطلقات و تطبيقات، الطبعة الثانية منقحة و مزيدة، وزارة التعليم العالى و البحث العلمى، جامعة موصل، نشرو طبع و توزيع دار الكتب للطباعة و النشر،

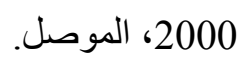
21. رسول، الدكتور عز الدين مصطفى، 2010، الواقعية فى الأدب الكردى، دار ئاراس للطباعة و النشر، الطبعة الثانية، أربيل.

22. شر ارة، د.حياة ، 1978، الأفكارو الأسلوب، أ.ف. تشتيشرين، دراسة فى الفن الرو ائية و لغته، ترجمة، الجمهورية العر اقية ـ وزارة البقافة و الفنون، بغداد، دار الحرية للطباعة. 23. الحمدانى، د. سالم أحمد، 1989، مذاهب الأدب العربى و مظاهر ها فى الأدب العربى الحديث.

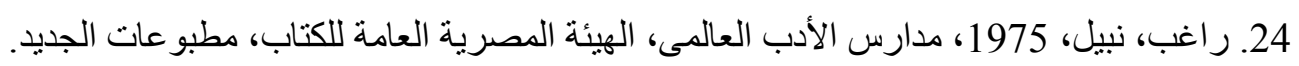
25. لؤلؤة، د. عبد الواحد، 1980، دئو، ديمين كر انت، موسوعة المصطلح النقدى، الو اقعية، دار الحرية للطباعة، بغداد. 26. خباز ، حنا، (د.ت.)، جمهورية أفلاطون، منشور ات مكتبة النهظة، مطبعة بابل، بغداد. 27. بدوى، عبدالرحمن، (د.ت.)، فن الثعر، أرسطو، نرجمة، دار، دار الثقافة، بيروت.

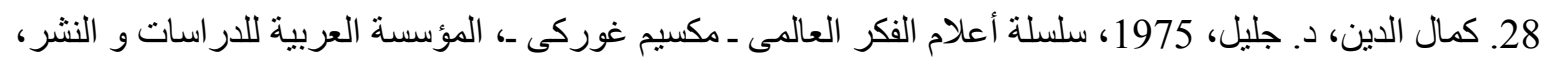
بيروت ـ لبنان، الطبعة الاولى. 
29. العامرى، م.م. مياده عبدالأمير كريم، 2014، الو اقعية السحرية فى رواية مستعرة المياه، جامعة زى قار، مجلة الأستاز، العدد 210، المجلد الأاول، 2014، 201.iasi.net

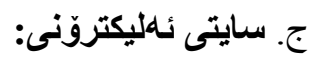

30

En.suomisanakivja.fi/eng;ish-sorani .31

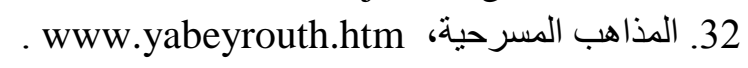

33. 33. المذهب الو اقعية، 32.

34. 37 مجلة صيد الفو ائد

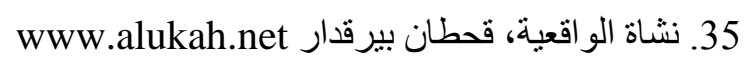

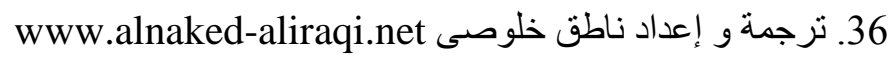

www.tegarahelwan.yoo7.com 37

يـهراويّز:

أ بروانه: خباز، حنا، (د.ت.)، جمهورية أفلاطون، منشورات مكتبة النهظة، مطبعة بابل، بغداد. و بدوى، عبدالرحمن، (د.ت.)، فن الشعر،

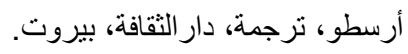

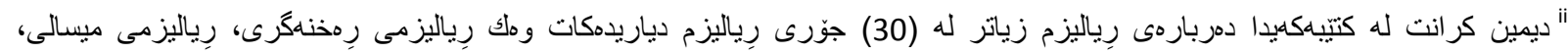

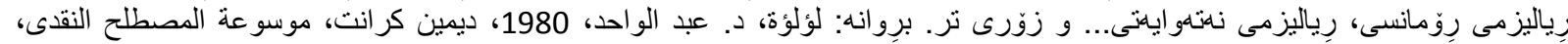
الوَ اقعية، دارَ الحرية للطُباعة ، بغداد. 